\title{
Water Budgets for Selected Watersheds in the Delaware River Basin, Eastern Pennsylvania and Western New Jersey
}

By Ronald A. Sloto and Debra E. Buxton

In cooperation with the

Delaware River Basin Commission

Scientific Investigations Report 2005-5113

U.S. Department of the Interior

U.S. Geological Survey 


\title{
U.S. Department of the Interior Gale A. Norton, Secretary
}

\author{
U.S. Geological Survey \\ P. Patrick Leahy, Acting Director
}

\section{U.S. Geological Survey, Reston, Virginia: 2005} For sale by U.S. Geological Survey, Information Services
Box 25286, Denver Federal Center
Denver, CO 80225
For more information about the USGS and its products:
Telephone: 1-888-ASK-USGS
World Wide Web: http://www.usgs.gov/
Any use of trade, product, or firm names in this publication is for descriptive purposes only and does not imply
endorsement by the U.S. Government.
Although this report is in the public domain, permission must be secured from the individual copyright owners to repro-
duce any copyrighted materials contained within this report. 


\section{Contents}

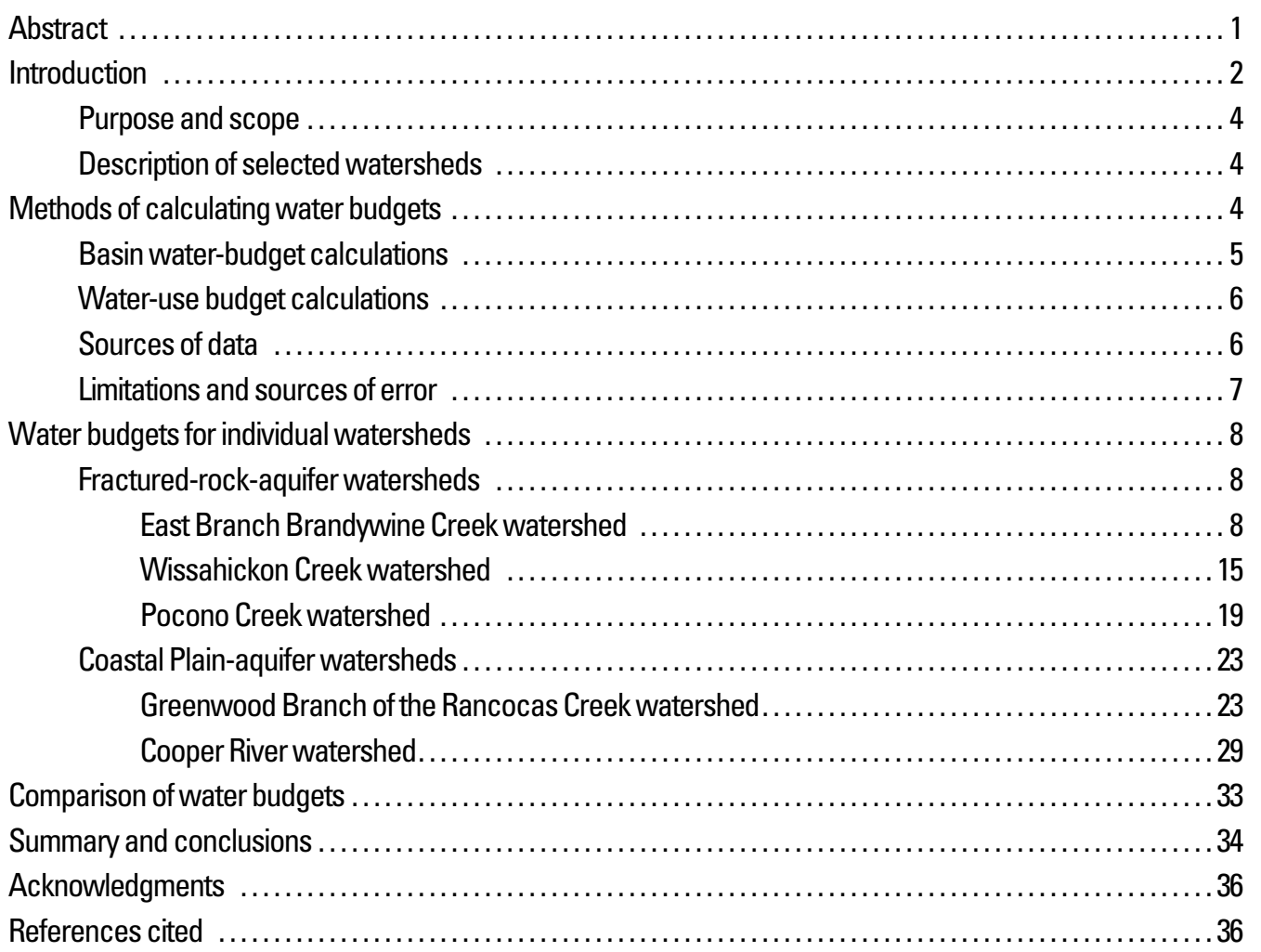




\section{Figures}

1. Map showing watersheds for which water budgets were prepared, Delaware River

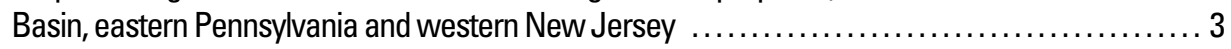

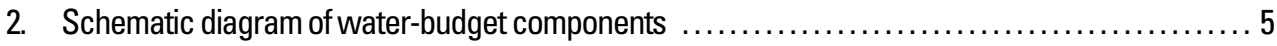

3. Map showing East Branch Brandywine Creek watershed, Chester County, Pennsylvania

4. Graph showing surface-water withdrawals and discharges, ground-water withdrawals, and imported water in the East Branch Brandywine Creek watershed, Chester County, Pennsylvania, 1977-2001

5. Map showing Wissahickon Creek watershed, Montgomery and Philadelphia Counties,

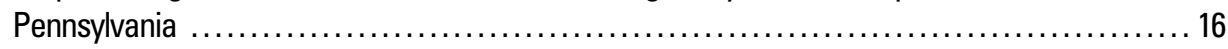

6. Graph showing surface-water discharges, ground-water withdrawals, and imported and exported water in the Wissahickon Creek watershed, Montgomery and Philadelphia Counties, Pennsylvania, 1987-98.

7. Map showing Pocono Creek watershed, Monroe County, Pennsylvania .................... 20

8. Graph showing relation between average daily discharge of Pocono Creek above Wigwam Run near Stroudsburg, Pennsylvania (01441495), and Brodhead Creek near Analomink, Pennsylvania (01440400), June 2002 to February 2004

9. Graph showing surface-water and ground-water withdrawals and ground-water exports in the Pocono Creek watershed, Monroe County, Pennsylvania, 1975-2001

10. Map showing Greenwood Branch of the Rancocas Creek watershed, Burlington and Ocean Counties, New Jersey

11. Graph showing surface-water and ground-water withdrawals and discharges and surfacewater exports in the Greenwood Branch of the Rancocas Creek watershed, Burlington and Ocean Counties, New Jersey, 1988-2002

12. Map showing Cooper River watershed, Camden and Burlington Counties, New Jersey ......... 30

13. Graph showing surface-water withdrawals and discharges and ground-water leakage in the Cooper River watershed, Camden and Burlington Counties, New Jersey, 1988-2002 


\section{Tables}

1. Drainage areas and streamflow-gaging station information for watersheds selected for development of water budgets in the Delaware River Basin, eastern Pennsylvania and

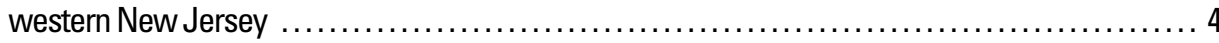

2. Basin water budget for the East Branch Brandywine Creek watershed, Chester County,

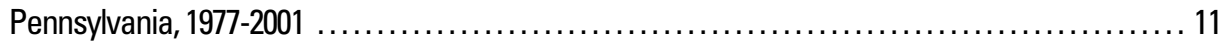

3. Water-use budget for the East Branch Brandywine Creek watershed, Chester County,

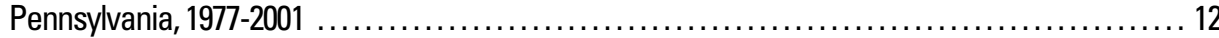

4. Base flow for the streamflow-gaging station East Branch Brandywine Creek below

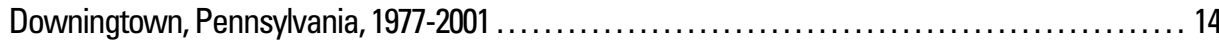

5. Basin water budget for the Wissahickon Creek watershed, Montgomery and Philadelphia

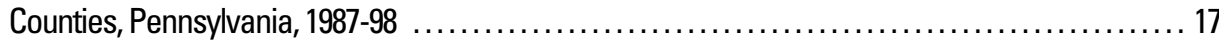

6. Water-use budget for the Wissahickon Creek watershed, Montgomery and Philadelphia

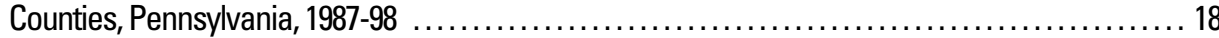

7. Base flow for the streamflow-gaging station Wissahickon Creek at Mouth, Philadelphia,

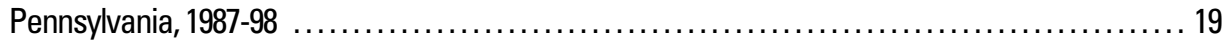

8. Basin water budget for the Pocono Creek watershed, Monroe County, Pennsylvania,

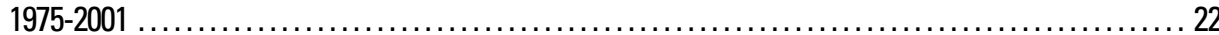

9. Water-use budget for the Pocono Creek watershed, Monroe County, Pennsylvania, $1975-2001$

10. Basin water budget for the Greenwood Branch of the Rancocas Creek watershed, Burlington and Ocean Counties, New Jersey, 1988-2002 ............................ 26

11. Water-use budget for the Greenwood Branch of the Rancocas Creek watershed, Burlington and Ocean Counties, New Jersey, 1988-2002 ............................. 28

12. Base flow for the streamflow-gaging station Greenwood Branch of the Rancocas

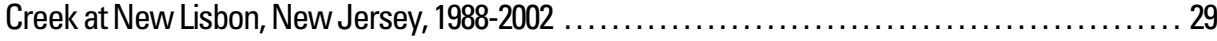

13. Basin water budget for the Cooper River watershed, Camden and Burlington Counties,

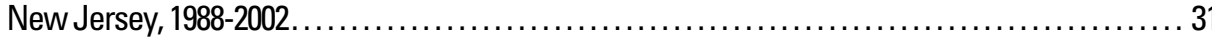

14. Water-use budget for the Cooper River watershed, Camden and Burlington Counties,

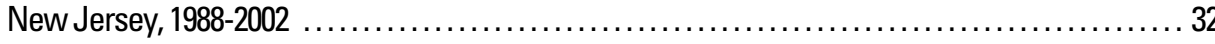

15. Base flow for the streamflow-gaging station Cooper River at Haddonfield, New Jersey, 1988-2002

16. Comparison of selected average values for water-budget components for the five watersheds for the common period of record, $1988-98$ 


\section{Conversion Factors}

\begin{tabular}{|c|c|c|}
\hline Multiply & By & To obtain \\
\hline \multicolumn{3}{|c|}{ Length } \\
\hline inch (in.) & 2.54 & centimeter $(\mathrm{cm})$ \\
\hline inch (in.) & 25.4 & millimeter $(\mathrm{mm})$ \\
\hline mile (mi) & 1.609 & kilometer (km) \\
\hline feet (ft.) & 0.3048 & meter $(\mathrm{m})$ \\
\hline \multicolumn{3}{|c|}{ Area } \\
\hline square mile $\left(\mathrm{mi}^{2}\right)$ & 2.590 & square kilometer $\left(\mathrm{km}^{2}\right)$ \\
\hline \multicolumn{3}{|c|}{ Volume } \\
\hline gallon (gal) & 3.785 & liter (L) \\
\hline \multicolumn{3}{|c|}{ Flow rate } \\
\hline cubic foot per second $\left(\mathrm{ft}^{3} / \mathrm{s}\right)$ & 0.02832 & cubic meter per second $\left(\mathrm{m}^{3} / \mathrm{s}\right)$ \\
\hline cubic foot per day $\left(\mathrm{ft}^{3} / \mathrm{d}\right)$ & 0.02832 & cubic meter per day $\left(\mathrm{m}^{3} / \mathrm{d}\right)$ \\
\hline gallon per day (gal/d) & 0.003785 & cubic meter per day $\left(\mathrm{m}^{3} / \mathrm{d}\right)$ \\
\hline million gallons per day $(\mathrm{Mgal} / \mathrm{d})$ & 0.04381 & cubic meter per second $\left(\mathrm{m}^{3} / \mathrm{s}\right)$ \\
\hline $\begin{array}{l}\text { million gallons per day per square mile } \\
{\left[(\mathrm{Mgal} / \mathrm{d}) / \mathrm{mi}^{2}\right]}\end{array}$ & 1,461 & $\begin{array}{l}\text { cubic meter per day per square kilo- } \\
\text { meter }\left[\left(\mathrm{m}^{3} / \mathrm{d}\right) / \mathrm{km}^{2}\right]\end{array}$ \\
\hline inch per year (in/yr) & 25.4 & millimeter per year $(\mathrm{mm} / \mathrm{yr})$ \\
\hline
\end{tabular}

\section{Abbreviations}

\section{Water-Budget Terms}
$\Delta S \quad$ Change in storage
$\triangle \mathrm{GWS}$ Change in ground-water storage
$\Delta S W S \quad$ Change in surface-water storage
CON Consumptive use
ET Evapotranspiration
GWEXP Ground-water exports
GWL Ground-water leakage to or from confined aquifers
GWR Return of water to the ground-water system as recharge
GWW Ground-water withdrawals
IMP Water imported into the watershed
$P \quad$ Precipitation
QGWW Ground water pumped for quarry or mine dewatering
RES Error in the water-budget term values
SF Streamflow leaving the watershed
SWD Discharge of water to streams in the watershed
SWW Surface-water withdrawal 


\title{
Other Abbreviations
}

\author{
DRBC Delaware River Basin Commission \\ GIS Geographical Information System \\ GWSI Ground-Water Site Inventory \\ HYSEP Hydrograph Separation Program \\ KRA Key Result Areas \\ NJDEP New Jersey Department of Environmental Protection \\ NOAA National Oceanic and Atmospheric Administration \\ RASA Regional Aquifer Systems Analysis \\ SWUDS Site Specific Water-Use Data System \\ USGS U.S. Geological Survey
}

WRPDRB Water Resources Plan for the Delaware River Basin 



\title{
Water Budgets for Selected Watersheds in the Delaware River Basin, Eastern Pennsylvania and Western New Jersey
}

\author{
by Ronald A. Sloto and Debra E. Buxton
}

\section{Abstract}

This pilot study, done by the U.S. Geological Survey in cooperation with the Delaware River Basin Commission, developed annual water budgets using available data for five watersheds in the Delaware River Basin with different degrees of urbanization and different geological settings. A basin water budget and a water-use budget were developed for each watershed. The basin water budget describes inputs to the watershed (precipitation and imported water), outputs of water from the watershed (streamflow, exported water, leakage, consumed water, and evapotranspiration), and changes in ground-water and surface-water storage. The water-use budget describes water withdrawals in the watershed (ground-water and surfacewater withdrawals), discharges of water in the watershed (discharge to surface water and ground water), and movement of water of water into and out of the watershed (imports, exports, and consumed water). The water-budget equations developed for this study can be applied to any watershed in the Delaware River Basin. Data used to develop the water budgets were obtained from available long-term meteorological and hydrological data-collection stations and from water-use data collected by regulatory agencies. In the Coastal Plain watersheds, net ground-water loss from unconfined to confined aquifers was determined by using ground-water-flow-model simulations. Error in the water-budget terms is caused by missing data, poor or incomplete measurements, overestimated or underestimated quantities, measurement or reporting errors, and the use of point measurements, such as precipitation and water levels, to estimate an areal quantity, particularly if the watershed is hydrologically or geologically complex or the data-collection station is outside the watershed. The complexity of the water budgets increases with increasing watershed urbanization and interbasin transfer of water. In the Wissahickon Creek watershed, for example, some ground water is discharged to streams in the watershed, some is exported as wastewater, and some is exported for public supply. In addition, ground water withdrawn outside the watershed is imported for public supply or imported as wastewater for treatment and discharge in the watershed. A GIS analysis was necessary to quantify many of the water-budget components.
The 89.9-square mile East Branch Brandywine Creek watershed in Pennsylvania is a rural watershed with reservoir storage that is underlain by fractured rock. Water budgets were developed for 1977-2001. Average annual precipitation, streamflow, and evapotranspiration were $46.89,21.58$, and 25.88 inches, respectively. Some water was imported (average of 0.68 inches) into the watershed for public-water supply and as wastewater for treatment and discharge; these imports resulted in a net gain of water to the watershed. More water was discharged to East Branch Brandywine Creek than was withdrawn from it; the net discharge resulted in an increase in streamflow. Most ground water was withdrawn (average of 0.25 inches) for public-water supply. Surface water was withdrawn (average of 0.58 inches) for public-water and industrial supply. Discharge of water by sewage-treatment plants and industries (average of 1.22 inches) and regulation by Marsh Creek Reservoir caused base flow to appear an average of 7.2 percent higher than it would have been without these additional sources. On average, 67 percent of the difference was caused by sewage-treatment-plant and industrial discharges, and 33 percent was caused by regulation of the Marsh Creek Reservoir. Water imports, withdrawals, and discharges have been increasing as the watershed becomes increasingly urbanized.

The 64-square mile Wissahickon Creek watershed in Pennsylvania is an urban watershed underlain by fractured rock. Water budgets were developed for 1987-98. Average annual precipitation, streamflow, and evapotranspiration were 47.23, 22.24 , and 23.12 inches, respectively. The watershed is highly urbanized, and there is a complex system of interbasin water transfers. Water was imported into the basin for public-water supply and as wastewater for treatment and discharge. Ground water was exported from the watershed for public-water supply. Because more water was exported (average of 1.78 inches) than imported (average of 1.64 inches), there was a net loss of water from the watershed. Most ground-water withdrawals (average 3.03 inches) were for public and industrial supply, whereas most surface-water withdrawals (average of 0.09 inches) were for golf course irrigation. A quarry in the watershed pumped a substantial quantity of ground water (average of 2.9 inches) for quarry dewatering. Water pumped for dewatering the quarry was equal, on average, to 49 percent of all ground-water 


\section{Water Budgets for Selected Watersheds in the Delaware River Basin, Eastern Pennsylvania and Western New Jersey}

withdrawals in the watershed. This water. discharged to the creek, constituted an average of 25 percent of the base flow of Wissahickon Creek. Discharge of water by sewage-treatment plants, industries, and the quarry (average total of 5.3 inches) caused base flow in the creek to appear higher than it would have been without these additional sources and constituted an average of about 44 percent of the observed base flow. Water imports, exports, withdrawals, and discharges have been steady over time.

The 46.5-square mile Pocono Creek watershed in Pennsylvania is a rural watershed underlain by fractured rock. Water budgets were developed for 1975-2001. Average annual precipitation, streamflow, and evapotranspiration were 49.70, 22.08, and 27.43 inches, respectively. Some water was exported from the watershed (average of 0.18 inches) for public-water supply. Most of the residents of the watershed relied on domestic wells and septic systems. Most of the nondomestic ground-water withdrawals (average of 0.52 inches) and all of the surfacewater withdrawals (average of 0.09 inches) and discharges (average of 0.07 inches) were by a ski resort. Water exports, withdrawals, and discharges have been increasing over time because of the growth of the ski industry and population growth in the Pocono Creek and surrounding watersheds.

The 77.9-square mile Greenwood Branch of the Rancocas Creek watershed in New Jersey is a rural watershed in the Coastal Plain dominated by forest and wetlands. Water budgets were developed for 1988-2002. Average annual precipitation, streamflow, and evapotranspiration were $44.73,18.25$, and 23.43 inches, respectively. Many private residences relied on domestic wells and septic systems. Most of the water supply, including that from half the domestic wells, came from confined aquifers. The majority of ground-water withdrawals (average of 0.44 inches) were for public supply and quarry dewatering (average of 1.14 inches). Water pumped for dewatering a sand quarry was equal, on average, to 72 percent of ground-water withdrawals in the watershed. Most surface-water withdrawals (average of 0.62 inches) were for public and agricultural supply. The main type of agriculture is cranberry production. Surface water was exported (average of 0.3 inches) for use at the Fort Dix Army Base, which is north of the watershed. Most consumptive use was for cranberry production and sand mining (average 0.14 inches). Ground-water returns (average of 1.42 inches) were dominated by the water used in cranberry production and quarry dewatering. Surface-water discharge (average of 0.31 inches) was mainly from cranberry production.

The 51.3-square mile Cooper River watershed in New Jersey is a mostly urban watershed in the Coastal Plain with an intricate system of water use. The southeastern part of the watershed is rural and was mainly self-supplied. Water budgets were developed for 1988-2002. Average annual precipitation, streamflow, and evapotranspiration were 44.11, 22.13, and 24.13 inches, respectively. Most of the water that was withdrawn and exported from the basin came from confined aquifers. The small amount of water withdrawn from unconfined aquifers (average of less than 0.01 inches) and surface-water sources (average 0.77 inches) was used for golf-course, agricultural, and nonagricultural irrigation and some industrial purposes. A regional sewer system completed in 1991 dramatically reduced discharge to surface water in the watershed from 2.95 inches in 1988 to 0.01 inches in 1994.

\section{Introduction}

Water is one of the Delaware River Basin's most important natural resources. The Delaware River, the largest undammed river east of the Mississippi, drains $12,765 \mathrm{mi}^{2}$, with 50.3 percent of the basin in Pennsylvania, 23.3 percent in New Jersey, 18.5 percent in New York, and 7.9 percent in Delaware (fig. 1). The large Philadelphia-Camden metropolitan area is in the Delaware River Basin, as well as the major cities of Dover and Wilmington, Del.; Trenton, N.J.; and Allentown, Pa. Nearly 15 million people (about 5 percent of the Nation's population) rely on the water of the basin for public-water supply and industrial use. New York City, which is outside the basin, utilizes reservoirs in the upper part of the basin for public-water supply.

In September 1999, the governors of the four Delaware River Basin states adopted a resolution directing the Delaware River Basin Commission (DRBC) to develop a new comprehensive water-resources plan for the basin. The Water Resources Plan for the Delaware River Basin (WRPDRB) presents a basinwide vision of long-range goals and directions to guide water-resources management. The plan provides a unified framework for addressing new and historic water-resource issues and problems in the Delaware River Basin. The WRPDRB uses a goal-based planning process that incorporates key result areas (KRA) with goals, objectives, and milestones (Delaware River Basin Commission, 2004).

The first KRA (KRA 1) in the WRPDRB is "Sustainable Use and Supply." The WRPDRB defines sustainability as "the use of a resource in a manner that meets current needs without compromising the ability to adequately meet the needs of future generations" (Delaware River Basin Commission, 2004, p. 93). The first goal under KRA 1 is "Equitably balance multiple demands on the limited water resources of the Basin, while preserving and enhancing conditions in watersheds to maintain or achieve ecological integrity." To meet this goal, it is necessary to assess current water use and to develop water budgets (Delaware River Basin Commission, 2004, p. 18-20).

A key element of water-resources planning is a systematic approach for comparing existing and future water withdrawals against available water supplies and environmental requirements. The two major components of water-resources planning include the development of water-supply and water-use data, sometimes referred to as the water budget, and allocation policy, such as withdrawal limits. Development of water-allocation policy generally entails assessment of the availability of water in a watershed, as well as the comparison of the effects of different allocation policies on both water allocation and environmental conditions. 


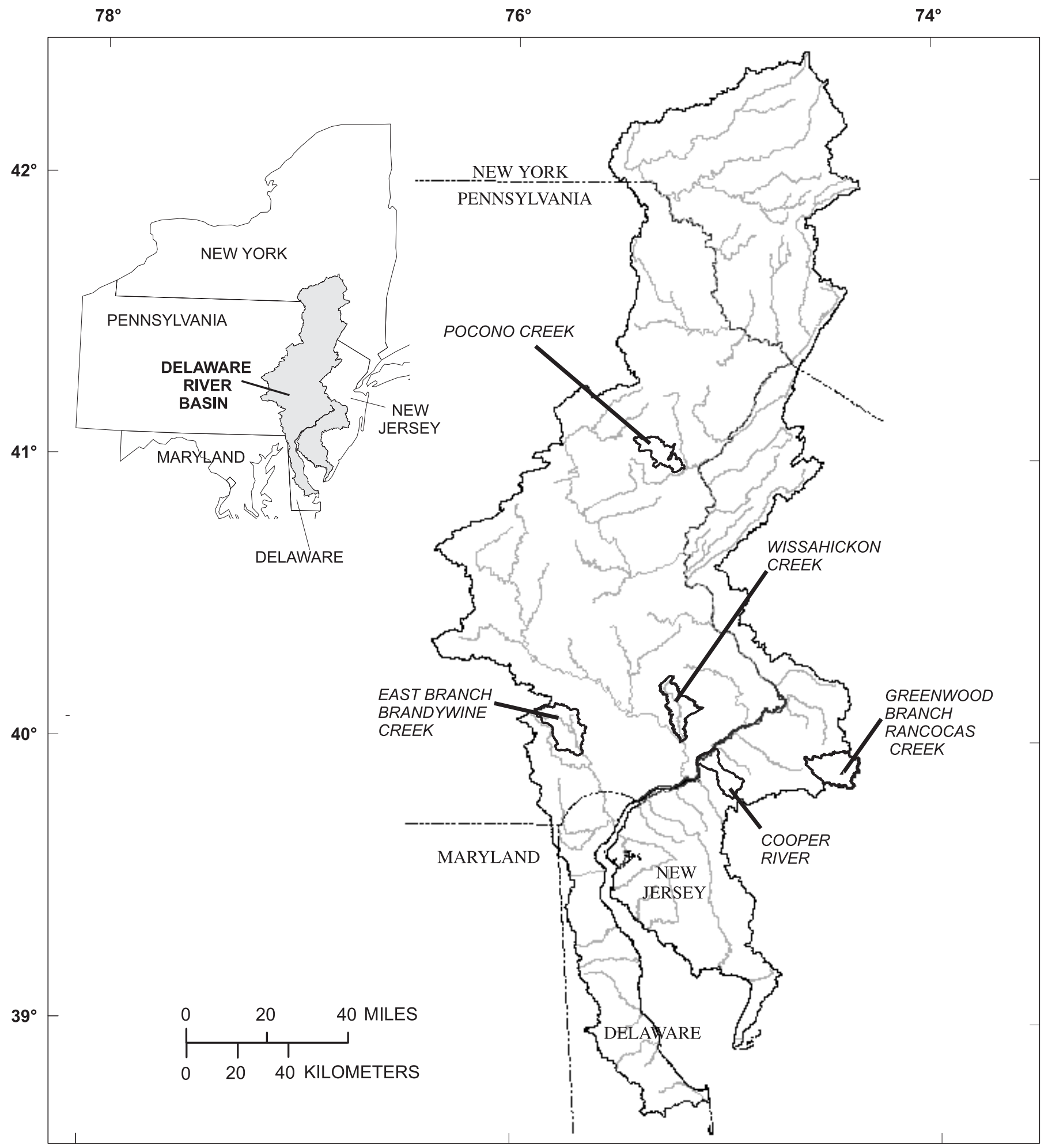

Base from U.S. Geological Survey digital data, 1972, 1:2,000,000 Albers Equal-Area Conicprojection Standard parallels $29^{\circ} 30^{\prime} \mathrm{N}$ and $45^{\circ} 30^{\prime} \mathrm{N}$, central meridian $75^{\circ} 00^{\prime} \mathrm{W}$

Figure 1. Watersheds for which water budgets were prepared, Delaware River Basin, eastern Pennsylvania and western New Jersey. 
This study was done by the U.S. Geological Survey (USGS) in cooperation with the DRBC as a pilot study to determine the feasibility of using available data to develop water budgets for watersheds in the Delaware River Basin. Water budgets were developed for five watersheds with different degrees of urbanization in different geologic settings. The results of this study provide water-resource managers and policy makers with a methodology for the development of water budgets, which can be used to compare the current use of water with the available water for watersheds in the Delaware River Basin.

\section{Purpose and Scope}

This report describes the methodology for developing annual basin water budgets water-use budgets. It presents annual water budgets for five selected watersheds in the Delaware River Basin. These include East Branch Brandywine Creek below Downingtown, Wissahickon Creek, and Pocono Creek in Pennsylvania, and the Greenwood Branch of the Rancocas Creek and the Cooper River in New Jersey. The span of years covered by the annual water budgets for each of the five watersheds differs because of differences in the availability of reliable water-use data. For this study, streamflow data were obtained from USGS streamflow-gaging stations. Precipitation data were obtained from available National Oceanic and Atmospheric Administration (NOAA) precipitation stations in or near each watershed. The annual change in ground-water storage was estimated from water-level records from USGS observation wells. Data on ground-water withdrawals, surface-water withdrawals, returns of water to the ground-water system, and discharge to streams were provided by the DRBC.

\section{Description of Selected Watersheds}

Five watersheds were chosen on the basis of their geologic setting and degree of urbanization for development of water budgets (fig. 1, table 1). Selected watersheds underlain by fractured rocks include the East Branch Brandywine Creek below Downingtown, Wissahickon Creek, and Pocono Creek watersheds. The East Branch Brandywine Creek watershed, which is becoming more urbanized, represents a watershed with reservoir storage (Marsh Creek Reservoir); the Wissahickon Creek watershed represents an urban watershed; and the Pocono Creek watershed represents a rural watershed. For the period covered by the water budgets, Pocono Creek was ungaged; therefore, the streamflow record from the adjacent Brodhead Creek watershed was used to estimate streamflow. Selected watersheds underlain by Coastal Plain sediments include the Greenwood Branch Rancocas Creek and Cooper River watersheds. The Greenwood Branch of the Rancocas Creek represents a rural watershed, and the Cooper River represents an urban watershed.

\section{Methods of Calculating Water Budgets}

Annual water budgets were developed for each of the five selected watersheds (fig. 1, table 1). The hydrologic system in a watershed is dynamic because water is always in motion. In a natural (undeveloped) watershed, water is constantly added by precipitation, and water is constantly leaving as surface water and evapotranspiration. The one common factor for all watersheds is that the total amount of water entering, leaving, and being stored in the system is conserved. An accounting of all the inflows, outflows, and changes in storage is called a water budget. Human activities, such as pumping ground water, change

Table 1. Drainage areas and streamflow-gaging station information for watersheds selected for development of water budgets in the Delaware River Basin, eastern Pennsylvania and western New Jersey.

$\left[\mathrm{mi}^{2}\right.$, square miles]

\begin{tabular}{|c|c|c|c|c|c|}
\hline Watershed & $\begin{array}{c}\text { Watershed } \\
\text { drainage } \\
\text { area } \\
\left(\mathrm{mi}^{2}\right)\end{array}$ & Streamflow-gaging station & $\begin{array}{l}\text { Station } \\
\text { number }\end{array}$ & $\begin{array}{c}\text { Station } \\
\text { drainage } \\
\text { area } \\
\left(\mathbf{m i}^{2}\right)\end{array}$ & $\begin{array}{l}\text { Station period of } \\
\text { record }\end{array}$ \\
\hline $\begin{array}{l}\text { East Branch Brandywine } \\
\text { Creek }\end{array}$ & 89.9 & $\begin{array}{l}\text { East Branch Brandywine Creek } \\
\text { below Downingtown, Pa. }\end{array}$ & 01480870 & 89.9 & 1972-current year \\
\hline Pocono Creek & 46.5 & $\begin{array}{l}\text { Streamflow estimated from Brodhead } \\
\text { Creek near Analomink, Pa. }\end{array}$ & 01440400 & 65.9 & 1957-current year \\
\hline Wissahickon Creek & 64.0 & $\begin{array}{l}\text { Wissahickon Creek at mouth, Phila- } \\
\text { delphia, Pa. }\end{array}$ & 01474000 & 64.0 & 1965-current year \\
\hline $\begin{array}{l}\text { Greenwood Branch of the } \\
\text { Rancocas Creek }\end{array}$ & 77.9 & $\begin{array}{l}\text { North Branch Rancocas Creek at } \\
\text { Pemberton, N.J. }\end{array}$ & 01467000 & 118 & 1921-current year \\
\hline Cooper River & 51.3 & Cooper River at Haddonfield, N.J. & 01467150 & 17.0 & 1963-current year \\
\hline
\end{tabular}


the natural system, and these changes must be accounted for in the calculation of the water budget. Because water that is used must come from somewhere, human activities affect the amount and rate of movement of water entering the system, in the system, and leaving the system (Alley and others, 1999).

Two types of water budgets were developed for each watershed. The basin water budget describes inputs to the watershed (precipitation and imported water), outputs of water from the watershed (streamflow, exported water, leakage, consumed water, and evapotranspiration), and changes in groundwater and surface-water storage. The water-use budget describes water withdrawals in the watershed (ground-water and surface-water withdrawals), discharges of water in the watershed (discharge to surface water and ground water), and movement of water into and out of the watershed (imports, exports, and consumed water).

\section{Basin Water-Budget Calculations}

Under natural conditions, the hydrologic system is in longterm equilibrium. Averaged over a long period of time (several tens of years), the amount of water entering the system is approximately equal to the amount of water leaving the system. Because the system is in long-term equilibrium, the quantity of water stored in the system is constant or varies about an average value in response to annual or longer term climatic variations.

An equation that describes the annual water budget of a natural system states that water input (I) equals discharge (D) plus or minus changes in water in storage $(\Delta S)$ :

$$
\mathrm{I}(\text { water entering system })=\mathrm{D}(\text { water leaving system }) \Delta \mathrm{S} \text {. (1) }
$$

In natural systems, water enters the system as precipitation $(\mathrm{P})$ and leaves the system as streamflow (SF) (surface runoff plus ground-water discharge to streams) and evapotranspiration (ET):

$$
\mathrm{P}=\mathrm{SF} \Delta \mathrm{S}+\mathrm{ET},
$$

where

$\mathrm{P}=$ precipitation,

$\mathrm{SF}=$ streamflow leaving the watershed,

$\Delta \mathrm{S}=$ change in storage, and

$\mathrm{ET}=$ evapotranspiration.

A schematic diagram of water-budget components is shown in figure 2.

In Coastal Plain watersheds, ground water is exchanged between unconfined and confined aquifers (GWL) in response to head gradients. In some areas, flow is upward or updip from confined aquifers to unconfined aquifers; this upward flow is a negative leakage. In other areas, flow is downward or downdip from unconfined aquifers to confined aquifers; this downward flow is a positive leakage. In a natural or predevelopment watershed, the equation used to describe the water budget is:

$$
\mathrm{P}=\mathrm{SF} \quad \Delta \mathrm{S} \quad \mathrm{GWL}+\mathrm{ET},
$$

where

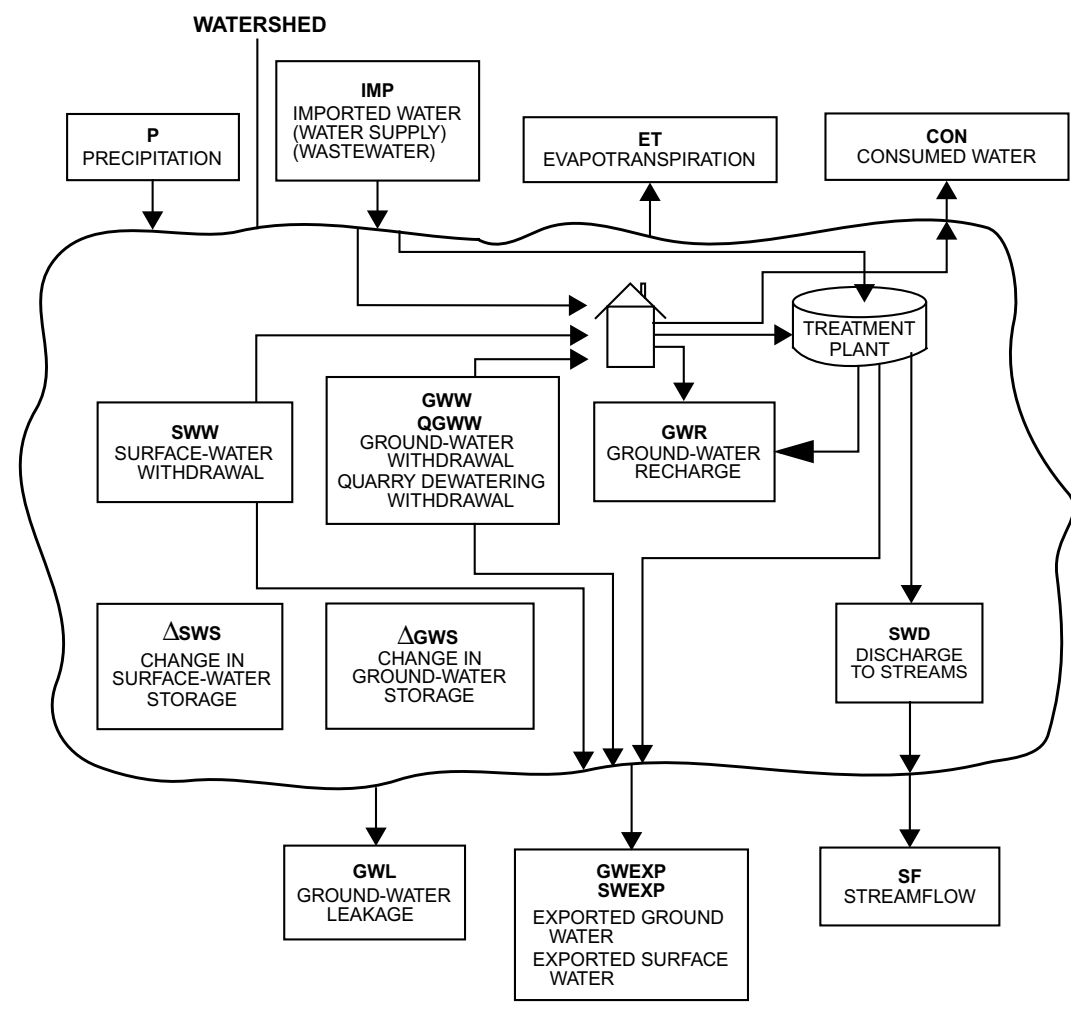

Figure 2. Schematic diagram of water-budget components.
GWL = ground-water leakage to or from confined aquifers.

Storage in the hydrologic system can be ground water stored in an aquifer ( $\Delta$ GWS), surface water stored in impoundments ( $\Delta$ SWS), and water stored in the soil ( $\Delta$ SMS). Changes in ground-water storage are caused by changes in recharge to the groundwater system and discharge from the ground-water system to streams (base flow), ground-water pumping, or ET directly from ground water. The quantity of water stored in the soil depends on precipitation, temperature, and plant cover. Soil moisture and changes in soil moisture are difficult to measure and may vary widely over a given area. Water budgets in this report are calculated on an annual basis with the start and end of the water budget in the early winter when soil moisture is at field capacity. Because the water budget begins and ends when the soil is saturated, the change in soil moisture is zero, and the $\Delta$ SMS term is not included in the water-budget equation:

$$
\mathrm{P}=\mathrm{SF} \quad \Delta \mathrm{GWS} \quad \Delta \mathrm{SWS} \text { GWL }+\mathrm{ET},
$$

where

$\Delta \mathrm{GWS}=$ change in ground-water storage, and $\Delta \mathrm{SWS}=$ change in surface-water storage. 


\section{Water Budgets for Selected Watersheds in the Delaware River Basin, Eastern Pennsylvania and Western New Jersey}

Human activity changes the natural hydrologic system in many ways. One way is by importing water into a watershed (IMP) and increasing the quantity available for use. Imported water can be water imported as a source of potable supply or as wastewater imported for treatment and discharge in the watershed. Another change is by exporting water (GWEXP,

SWEXP) from the watershed. Some human activities result in the consumption of water (CON), which can be viewed as an export from the watershed. Consumptive use includes water loss from irrigation (agricultural, golf-course, or land application of treated sewage effluent) and in bottled water or manufactured products. An equation describing the water budget for a watershed influenced by human activity, which is referred to as the basin water budget in this report, is

$$
\begin{aligned}
& \mathrm{P}+\mathrm{IMP}=\mathrm{SF} \Delta \mathrm{GWS} \Delta \mathrm{SWS} \mathrm{GWL} \\
& +\mathrm{GWEXP}+\mathrm{SWEXP}+\mathrm{CON}+\mathrm{ET}
\end{aligned}
$$

where

IMP = water imported into the watershed,

$\mathrm{CON}=$ consumptive use,

GWEXP = ground-water withdrawals exported from the watershed, and

SWEXP = surface-water withdrawals exported from the watershed.

For a particular watershed, an annual basin water budget can be estimated by using the appropriate form of equation 5 . Only those terms applicable to the particular watershed should be included in the equation. Because all terms in equation 5 can be measured or reasonably estimated except ET, the equation is solved for ET. Errors in the calculation or estimation of the other terms affect the calculated ET and are included in the ET term.

\section{Water-Use Budget Calculations}

To provide water managers with information on the use and movement of water within a watershed as well as to and from a watershed, a water-use budget was developed for each of the five watersheds. Water that is pumped from wells (GWW) may be exported from the watershed (GWEXP), used within the watershed and returned to the ground-water system as recharge from septic systems and irrigation (GWR), discharged to streams by sewage-treatment plants or industries (SWD), or consumed (CON). In some watersheds, pumping of ground water for quarry or mine dewatering (QGWW) is substantial and may be the largest withdrawal in the watershed. Generally QGWW is a point withdrawal, and most of the pumped water is discharged to a nearby stream (SWD). Water that is withdrawn from streams and impoundments (SWW) may be exported from the watershed (SWEXP), returned to the stream as discharge from sewage-treatment plants or industrial discharge (SWD), returned to the ground-water system as recharge from septic systems and irrigation (GWR), or consumed (CON). Often, water imported (IMP) to a watershed as potable water is used and discharged to streams through sewage-treatment plants. Some imported water is wastewater that is treated and discharged to streams in the watershed. If all of these terms can be quantified and all of the water can be accounted for, then the sum of the terms would equal zero. An equation that includes terms for ground-water and surface-water flux within a watershed is:

$$
\begin{array}{r}
\mathrm{IMP}+\mathrm{GWW}+\mathrm{QGWW}-\mathrm{GWEXP}-\mathrm{GWR} \\
+\mathrm{SWW}-\mathrm{SWEXP}-\mathrm{SWD}-\mathrm{CON}=0,
\end{array}
$$

where

GWW = ground-water withdrawal, QGWW = ground water pumped for quarry or mine dewatering,

GWR = return of water to the ground-water system as recharge,

SWW = surface-water withdrawal, and

SWD = discharge of water to streams in the watershed.

In reality, complete data usually are not available for all terms in equation 6 , and the quantities for many of the terms are estimated. Unless precise data are available for all terms in equation 6 , the terms on the left side of the equation will not equal zero, but will be equal to a residual (RES). This residual is equal to the error in the water-budget terms caused by missing data, poor or incomplete measurements, and overestimated or underestimated quantities. An equation describing the water movement within a watershed, as well as to and from a watershed, referred to as the water-use budget in this report, is:

$$
\begin{array}{r}
\mathrm{IMP}+\mathrm{GWW}+\mathrm{QGWW}-\mathrm{GWEXP}-\mathrm{GWR} \\
+\mathrm{SWW}-\mathrm{SWEXP}-\mathrm{SWD}-\mathrm{CON}=\mathrm{RES},
\end{array}
$$

where

RES = error in the water-budget term values.

A water-use budget can be estimated by using the appropriate form of equation 7. Only those terms applicable to the watershed should be included in the equation. Quantities for all terms in equation 7 can be obtained from water-withdrawal and water-discharge databases, with the possible exception of consumptive use (CON), which can be estimated or calculated from the water-use data. If the quantities of all terms are reliably known, RES should equal zero. If the quantities of all terms are not reliably known, RES represents the error.

\section{Sources of Data}

Precipitation data $(\mathrm{P})$ were obtained from available National Oceanic and Atmospheric Administration (NOAA) precipitation stations in or near each watershed. Average precipitation over the watershed where data from multiple stations were available was estimated by using the Thiessen polygon method of areal rainfall determination (Thiessen, 1911). The Thiessen method subdivides a watershed into polygonal subareas with the precipitation stations as centers. The polygo- 
nal subareas are used to assign a weight to the rainfall amount at the station in the center of the polygon. The Thiessen network is fixed for a given precipitation-gage distribution. When a precipitation gage is added, removed, or moved to a new location, the polygons (and therefore the weights) must be recalculated.

Streamflow data (SF) were obtained from USGS streamflow-gaging stations. Because streamflow data were not available for the Pocono Creek watershed for the period covered by the water budgets, streamflow was estimated on the basis of the record of a nearby streamflow-gaging station in the Brodhead watershed. Data to calculate the annual change in storage $(\triangle \mathrm{SWS})$ in the Marsh Creek Reservoir were taken from the USGS Annual Reports and Sloto (1994). Because streamflow data were not available for the Greenwood Branch of Rancocas Creek for the period covered by the water budget, streamflow was estimated from the record of downstream station North Branch Rancocas Creek at Pemberton, N.J. (station 01467000).

The annual change in ground-water storage ( $\triangle \mathrm{GWS}$ ) was estimated from water-level records from USGS observation wells. If daily water levels were available, the annual change in water level was calculated by subtracting the January 1 water level from the December 31 water level, converting the difference to inches, and multiplying the result by the specific yield of the aquifer. If monthly water levels were available, the annual change in water level was calculated by subtracting the December water level from the previous year's December water level, converting the difference to inches, and multiplying by the result by the specific yield of the aquifer.

Data were provided by the DRBC on ground-water withdrawals (GWW), surface-water withdrawals (SWW), returns of water to the ground-water system (GWR), and discharge to streams (SWD). In a few instances, additional data were obtained from published reports or by contacting water suppliers. The ground-water and surface-water withdrawal and discharge data were used to determine water imports (IMP) and exports (GWEXP and SWEXP) by means of a Geographic Information System (GIS) analysis. The GIS analysis used point data sets for withdrawal and discharge sites and data sets depicting water-supply and sewage-system service areas. The main consumptive use was golf-course and agricultural irrigation. The data were fairly complete for the New Jersey watersheds, but incomplete for the Pennsylvania watersheds.

Current-year water-use data are collected in Pennsylvania, but are not retained in a historical database. In addition, the wateruse data for Pennsylvania have not been computerized for all years.

Missing water-use data were estimated by using linear interpolation between years for which data were available, or the data were assumed to be the same as during the preceding or past year. Data for some small dischargers were available for only 1 year; discharge for these users is small and was assumed to be constant during the period of water-budget calculation.

For the Coastal Plain watersheds, ground-water leakage (GWL) from the unconfined aquifer to the confined aquifers is in response to natural and induced head gradients across the confining layers. Ground-water flow throughout the New Jer- sey Coastal Plain under prepumping and pumping (in 1978) flow regimes was described by Martin (1998) as part of the USGS Regional Aquifer-System Analysis (RASA) Program. The RASA model has been updated and rediscretized with 0.25 -mi grid spacing in the interior of the model domain, so more recent flow conditions can be evaluated at a greater spatial resolution (Voronin, 2004). Within zones that correspond well with watershed boundaries, calculation of simulated vertical flow through confining units and horizontal flow in the downdip direction to confined aquifer layers provided an estimate of GWL (A.D. Gordon, U.S. Geological Survey, oral commun., 2004). The leakage at each node within the zone was added to give the total leakage for the watershed.

\section{Limitations and Sources of Error}

The water-budget equations developed for this study can be applied to any watershed in the Delaware River Basin. They were applied to watersheds with drainage areas ranging from 46.5 to $89.9 \mathrm{mi}^{2}$. The water-budget component values are given in inches so that watersheds can be compared regardless of their drainage area. Inches in the water budgets may be converted to million gallons per day per square mile by multiplying by 0.048 .

The size of the watershed influences the magnitudes of some water-budget components. The magnitude of waterbudget components that are areally distributed over the watershed, such as precipitation (P), streamflow (SF), storage ( $\Delta \mathrm{GWS}, \Delta \mathrm{SWS}$ ), and ET, are not affected by watershed size. For example, an average annual precipitation of $45 \mathrm{in}$. will be the same for a $5-\mathrm{mi}^{2}$ watershed as for a $100-\mathrm{mi}^{2}$ watershed. The magnitudes of water-budget components that are point measurements, such as withdrawals (GWW, QGWW, SWW), discharges (GWR, SWD), imports (IMP), exports (GWEXP, SWEXP), and consumptive use (CON), are affected by watershed size. For example, a withdrawal of $1 \mathrm{Mgal} / \mathrm{d}$ will be equal to $4.2 \mathrm{in}$. for a $5-\mathrm{mi}^{2}$ watershed but only $0.2 \mathrm{in}$. for a $100-\mathrm{mi}^{2}$ watershed.

Because the basin water-budget equation (eq. 5) is solved for ET, errors in the measurement or estimation of the other terms affect the calculated ET. Therefore, the ET term is evapotranspiration plus errors.

Precipitation data were obtained from available NOAA precipitation stations in or near each watershed. Most stations had missing data, which were estimated by substituting values from nearby stations. In addition, there may be errors in the measurement of precipitation. Precipitation measured at one or more precipitation gages, some of which may be outside the watershed, may not be fully representative of the actual precipitation falling on the watershed. Errors also result from using point precipitation measurements to estimate areal precipitation.

Some error may be associated with the streamflow record used to calculate the SF term. The five watersheds selected for this study had streamflow-gaging stations. Because the period of record for the streamflow-gaging station on Pocono Creek 


\section{Water Budgets for Selected Watersheds in the Delaware River Basin, Eastern Pennsylvania and Western New Jersey}

started after the period covered by the water budgets, streamflow for this watershed was estimated from the record in an adjacent watershed, so there is error associated with the estimated record. The accuracy of streamflow records ranges from excellent to poor, and may vary from year to year and within a given year. A rating of "excellent" means that 95 percent of the daily discharges are within 5 percent of their true values; a rating of "good" means that 95 percent of the daily discharges are within 10 percent of their true values; a rating of "fair" means that 95 percent of the daily discharges are within 15 percent of their true values; and a rating of "poor" means that the record does not meet these criteria (Durlin and Schaffstall, 2004, p. 16).

Water-level data from long-term USGS observation wells were used to estimate the annual change in ground-water storage. For Pennsylvania, only one USGS long-term observation well is in each county. In Chester County the USGS maintains a county-wide network of wells that are measured monthly. Only the East Branch Brandywine Creek and Greenwood Branch Rancocas Creek watersheds have an observation well within the watershed boundary. For the other watersheds, the change in ground-water storage was estimated using data from the nearest observation well, which was outside the watersheds. Error is associated with using one or two point measurements (water levels) to estimate a basin-wide change in ground-water storage, especially when the well is outside the watershed; the well may not represent the average change in ground-water storage for the entire watershed. Additional error is associated with using a well in one geologic unit if the watershed is underlain by one or more different geologic units. The change in ground-water storage varies from year to year. Over the long term, the average change in ground-water storage is equal to zero. In the basin water budgets presented in this report, the long-term average change in ground-water storage does not equal zero because of the short period of record of some of the water budgets and because of the estimation of specific yield; it does not reflect a decline in aquifer storage over time.

Error in the water-use budget equation (equation 7) is represented in the residual term (RES). Errors are associated with reported water-use data. The data are incomplete and were estimated for almost all suppliers and dischargers for at least some years. Some reported water-use data are not accurate or may be estimated where meters are not used or not functioning. In addition, not all suppliers and dischargers report their water use. In Pennsylvania, suppliers in the DRBC's Ground-Water Protected Area (Delaware River Basin Commission, 1999) who withdraw more than 10,000 gal/day are required to file a report. In the rest of the Delaware River Basin in Pennsylvania, suppliers who withdraw more than $100,000 \mathrm{gal} / \mathrm{day}$ are required to file a report. In New Jersey, suppliers with the capacity to pump $100,000 \mathrm{gal}$ or greater in a 24 -hour period are required to have a permit from the New Jersey Department of Environmental Protection (NJDEP), and those who pump less than $100,000 \mathrm{gal} /$ day are issued water-allocation permits (Nawyn, 1997). Not all types of water-use and discharge data are readily available. Data were not available for self-supplied domestic use or septic-system discharge. In addition, consumptive use for public or domestic water supply generally is not available.

In New Jersey, water budgets were developed for the unconfined system only. Large-capacity dischargers for the two New Jersey Coastal Plain watersheds, the Camden County and Pemberton Municipal Utility Authorities, discharge water that mainly comes from confined aquifers, and both discharge outside the watersheds.

GWL in the Coastal Plain watersheds was estimated by using the RASA ground-water-flow model. RASA model leakage data, however, are available only up to 1998. Leakage for 1999-2002 was estimated using 1998 data.

All consumptive water use (CON) was estimated. Most uses of water have a consumptive-use component, but consumptive use is difficult to estimate. If withdrawal and discharge data were available for a user, the difference was considered consumptive use. Most users, however, had either withdrawal or discharge data available but not both. In addition, multiple withdrawers may contribute to one or more discharges. If not explicitly estimated, consumptive use was included in the ET value.

\section{Water Budgets for Individual Watersheds}

Basin water budgets and water-use budgets are presented for the five selected watersheds in the following sections. The time period covered by the water budgets differs among the watersheds because of differences in the availability of reliable water-use data.

\section{Fractured-Rock-Aquifer Watersheds}

Annual water budgets were developed for three watersheds underlain by fractured rocks. These watersheds are the East Branch Brandywine Creek and Wissahickon Creek watersheds in southeastern Pennsylvania and the Pocono Creek watershed in northeastern Pennsylvania (fig. 1).

\section{East Branch Brandywine Creek Watershed}

The 89.9- $\mathrm{mi}^{2}$ East Branch Brandywine Creek watershed above streamflow-gaging station East Branch Brandywine Creek below Downingtown, Pa. (station 01480870) represents a fractured-rock watershed with reservoir storage (Marsh Creek Reservoir) (fig. 3). The watershed is undergoing a change from rural to suburban. Some residential developments are served by public-water systems and may be served by public-sewer systems, but many of the residents are self-supplied by domestic wells. The watershed includes the Borough of Downingtown, which uses East Branch Brandywine Creek as a source of water supply.

The period for which annual water budgets were calculated (1977-2001) was governed by the availability of water-use 


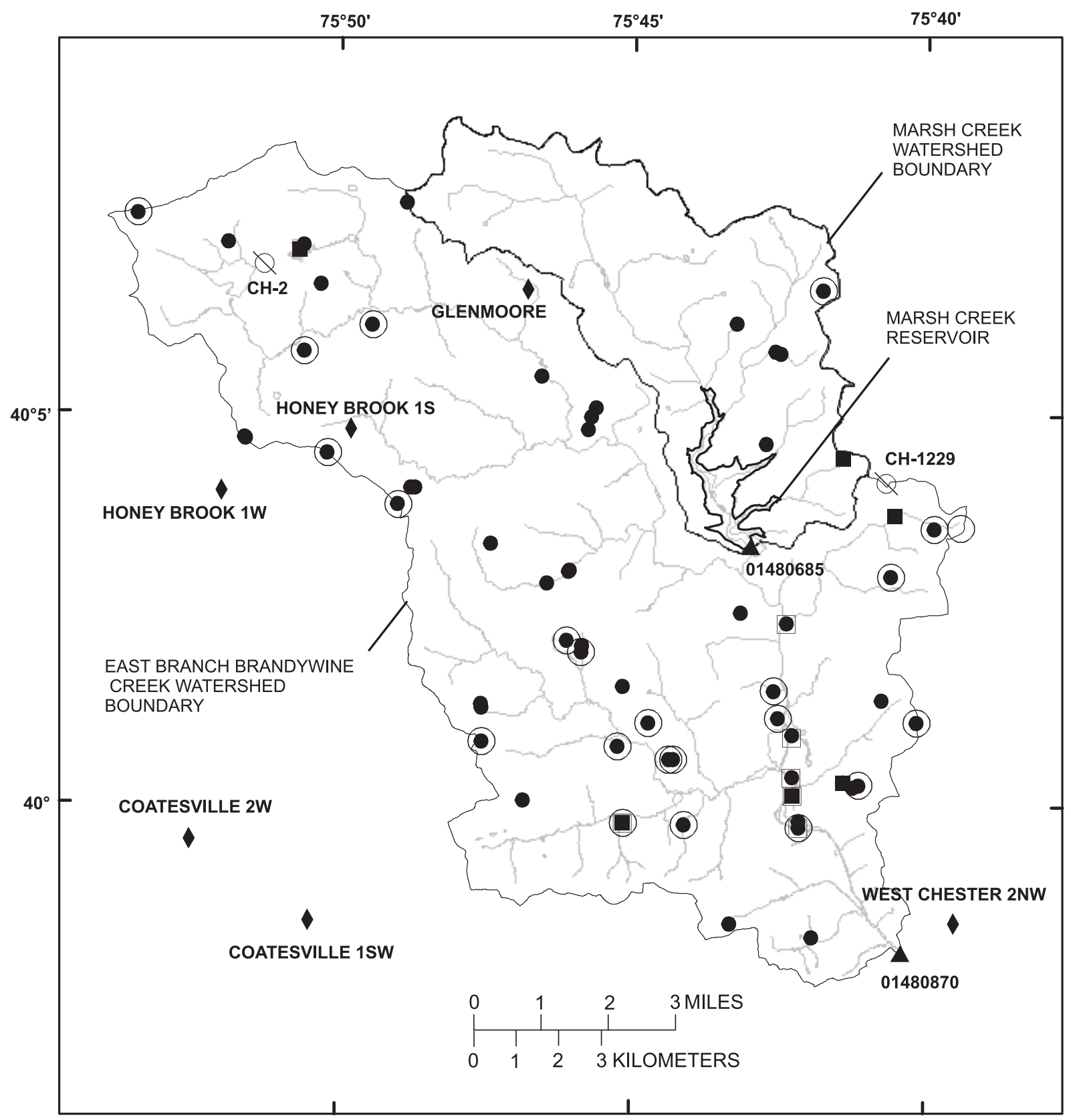

Base from U.S. Geological Survey digital data, 1972, 1:2,000,000 Albers Equal-Area Conicprojection Standard parallels $29^{\circ} 30^{\prime} \mathrm{N}$ and $45^{\circ} 30^{\prime} \mathrm{N}$, central meridian $75^{\circ} 00^{\prime} \mathrm{W}$

\section{EXPLANATION}

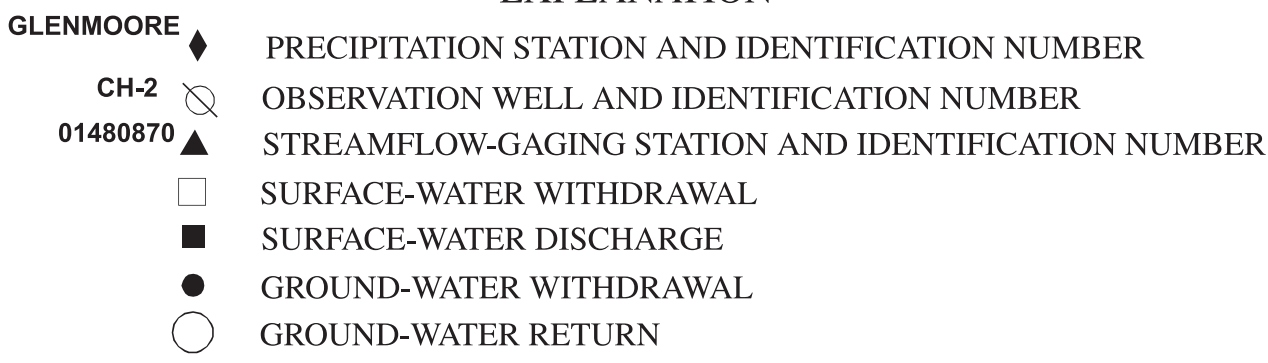

Figure 3. East Branch Brandywine Creek watershed, Chester County, Pennsylvania. Location of watershed shown on figure 1. 
data. Ground-water-withdrawal, surface-water-withdrawal, and discharge data were provided by the DRBC. These data were supplemented with data from Aqua Pennsylvania, Inc., Downingtown Municipal Authority, Downingtown Area Regional Authority, Chester County Planning Commission (1985a, 1985b, 1991, and 1996), Chester County Water Resources Authority and Chester County Planning Commission (1979), Chester County Water Resources Authority (2001), and USGS files.

For the East Branch Brandywine Creek watershed, the following equation was used to calculate the basin water budget:

$$
\begin{aligned}
\mathrm{P}+\mathrm{IMP} & =\mathrm{SF} \Delta \mathrm{GWS} \Delta \mathrm{SWS} \\
& +\mathrm{GWEXP}+\mathrm{CON}+\mathrm{ET} .
\end{aligned}
$$

The basin water-budget equation (eq. 5) was adjusted for conditions in the East Branch Brandywine Creek watershed. This watershed does not have surface-water exports or leakage to underlying confined units; therefore, those terms are not included in equation 8 .

Basin water budgets for the East Branch Brandywine Creek watershed for 1977-2001 are presented in table 2. The ET term, which includes evapotranspiration plus all errors in measurement or estimation of the other water-budget terms, ranged from $22.69 \mathrm{in}$. in 1983 to $29.73 \mathrm{in}$. in 1981 and averaged 25.88 in. The average annual potential ET estimated by Jenner and Lins (1991, p. 100) for the East Branch Brandywine Creek watershed is about 27 to 28 in.

Digital precipitation data were available from six NOAA precipitation gages: Coatesville 1SW (1948-1982), Coatesville 2W (1983-2001), Glenmoore (1956-2001), Honey Brook 1S (1965-96), Honey Brook 1W (1996-2001), and West Chester 2NW (1948-91, 1999-2001) (fig. 3). Five Thiessen polygon nets were created corresponding to five sets of precipitation-gage locations: 1977-82, 1983-91, 1992-95, 1996-98, and 1999-2001. For each Thiessen polygon net, weights were determined for each station, and an annual precipitation for the watershed was calculated. The Glenmoore station received the most weight (39 to 64 percent). Annual precipitation (P) ranged from 35.41 in. in 1980 to 69.34 in. in 1996 and averaged 46.89 in. (table 2).

Data from USGS streamflow-gaging station East Branch Brandywine Creek below Downingtown, Pa., was used to calculate the streamflow component of the water budgets. Streamflow (SF) ranged from 9.74 in. in 1981 to 41.30 in. in 1996 and averaged 21.58 in. (table 2).

Water-level data used to estimate the annual change in ground-water storage were available for two wells in the watershed: $\mathrm{CH}-2$ and $\mathrm{CH}-1229$ (fig. 3). These wells are measured monthly. The water level in well $\mathrm{CH}-2$ fluctuates in the weathered zone; December water levels ranged from 6 to $14 \mathrm{ft}$ below land surface. The annual change in water level in well CH-2 was multiplied by a specific yield of 0.08 (McGreevy and Sloto, 1980, p. 18) to calculate the change in ground-water storage. The water level in well $\mathrm{CH}-1229$ fluctuates in fractured rock below the casing; December water levels ranged from 32 to $43 \mathrm{ft}$ below land surface. The annual change in water level in well $\mathrm{CH}-1229$ was multiplied by an estimated specific yield of 0.04 to give the change in ground-water storage. The annual changes in ground-water storage were averaged to calculate the change in ground-water storage for the watershed. The annual change in ground-water storage ( $\Delta$ GWS) ranged from a loss of 4.35 in. in 1997 to a gain of 3.30 in. in 1983 and averaged -0.11 in. (table 2).

The Marsh Creek Reservoir is a multipurpose reservoir used for flood control, public-water supply, and recreation. Withdrawals are not made directly from the reservoir. Water is released to downstream users who withdraw water directly from East Branch Brandywine Creek. The change in surfacewater storage for the Marsh Creek Reservoir was converted to inches for the entire 89.9- $\mathrm{mi}^{2}$ watershed. The change in surfacewater storage ( $\Delta \mathrm{SWS}$ ) ranged from -0.74 in. in 1988 to $0.56 \mathrm{in}$. in 1983 and averaged -0.01 in. (table 2).

A GIS analysis that combined water and sewer service areas (provided by the Chester County Water Resources Authority) with water-withdrawal and discharge-point data was used to determine imported and exported water. For service areas with a source of water outside the basin and discharge within the basin, water was considered to be imported. For service areas with a source of water inside the basin and discharge outside the basin, water was considered to be exported.

Imported water (IMP) ranged from 0.31 in. in 1977 to 1.23 in. in 1996 and averaged 0.68 in. (table 2 ). The quantity of exported ground water (GWEXP) is small; it ranged from 0 for 1977-96 to 0.02 in. for $1999-2001$ and averaged less than 0.01 in. No surface water was exported.

Consumptive water use $(\mathrm{CON})$ was estimated from the data provided by the DRBC as the difference between publicsupply and industrial withdrawals and discharges. Consumptive use (CON) ranged from 0.16 in. in 1977-78 to 0.37 in. in 1997 and averaged 0.23 in. (table 2).

For the East Branch Brandywine Creek watershed, the following equation was used to calculate the water-use budget:

$$
\begin{aligned}
& \text { IMP + GWW - GWEXP - GWR } \\
& + \text { SWW - SWD - CON = RES. }
\end{aligned}
$$

The water-use budget equation (eq. 7) was adjusted for conditions in the East Branch Brandywine Creek watershed. This watershed does not have surface-water exports or ground-water pumping for quarry operations; therefore, those terms are not included in equation 9. Water-use budgets for the East Branch Brandywine Creek watershed for 1977-2001 are presented in table 3.

Water-withdrawal data were available for most users for most years. No data were available for 1986 and 1987 except from the Downingtown Municipal Authority and for 1996 except from the Downingtown Municipal Authority and Aqua Pennsylvania, Inc.; data for these years were estimated. Missing data were interpolated or assumed to be the same as they were during the preceding or past year. Ground-water withdrawals 
Table 2. Basin water budget for the East Branch Brandywine Creek watershed, Chester County, Pennsylvania, 1977-2001.

[All units are given in inches]

\begin{tabular}{|c|c|c|c|c|c|c|c|c|}
\hline Year & $\begin{array}{l}\text { Precipitation } \\
\text { (P) }\end{array}$ & $\begin{array}{l}\text { Imported } \\
\text { water } \\
\text { (IMP) }\end{array}$ & $\begin{array}{l}\text { Streamflow } \\
\text { (SF) }\end{array}$ & $\begin{array}{l}\text { Change in } \\
\text { ground-water } \\
\text { storage } \\
\text { ( } \Delta \text { GWS })\end{array}$ & $\begin{array}{c}\text { Change in } \\
\text { surface- } \\
\text { water } \\
\text { storage } \\
(\Delta \text { SWS })\end{array}$ & $\begin{array}{l}\text { Ground- } \\
\text { water } \\
\text { exports } \\
\text { (GWEXP) }\end{array}$ & $\begin{array}{l}\text { Consumptive use } \\
\text { (CON) }\end{array}$ & $\begin{array}{c}\text { Evapotranspiration } \\
\text { (ET) } \\
\text { and errors }\end{array}$ \\
\hline 1977 & 49.86 & 0.31 & 20.50 & 1.76 & 0.08 & 0.00 & 0.16 & 27.67 \\
\hline 1978 & 51.61 & .44 & 29.64 & -.55 & -.36 & .00 & .16 & 23.16 \\
\hline 1979 & 59.50 & .50 & 34.26 & .13 & -.06 & .00 & .19 & 25.48 \\
\hline${ }^{1} 1980$ & 35.41 & .39 & 15.52 & -3.31 & .18 & .00 & .17 & 23.24 \\
\hline 1981 & 39.03 & .43 & 9.74 & -.18 & .00 & .00 & .17 & 29.73 \\
\hline 1982 & 45.27 & .51 & 20.56 & 1.80 & -.35 & .00 & .17 & 23.60 \\
\hline 1983 & 57.01 & .68 & 30.95 & 3.30 & .56 & .00 & .19 & 22.69 \\
\hline 1984 & 53.66 & .82 & 33.31 & -2.83 & -.42 & .00 & .18 & 24.24 \\
\hline 1985 & 44.11 & .58 & 15.10 & .98 & .09 & .00 & .21 & 28.31 \\
\hline 1986 & 42.87 & .61 & 18.26 & -.32 & .00 & .00 & .21 & 25.33 \\
\hline 1987 & 42.80 & .57 & 18.01 & -.72 & .27 & .00 & .18 & 25.63 \\
\hline${ }^{2} 1988$ & 46.55 & .61 & 21.20 & -.15 & -.74 & .00 & .21 & 26.64 \\
\hline 1989 & 52.31 & .83 & 25.81 & .74 & .38 & .00 & .24 & 25.97 \\
\hline 1990 & 47.47 & .76 & 19.74 & -.22 & .39 & .00 & .25 & 28.07 \\
\hline 1991 & 40.68 & .77 & 16.39 & -.66 & -.26 & .00 & .26 & 25.72 \\
\hline 1992 & 41.67 & .79 & 14.45 & .96 & -.03 & .00 & .25 & 26.83 \\
\hline 1993 & 50.23 & .93 & 26.19 & -1.06 & -.02 & .00 & .26 & 25.79 \\
\hline 1994 & 47.65 & .49 & 23.22 & -.15 & -.02 & .00 & .28 & 24.81 \\
\hline 1995 & 41.15 & .86 & 14.84 & .76 & -.03 & .00 & .26 & 26.18 \\
\hline${ }^{3} 1996$ & 69.34 & 1.23 & 41.30 & 2.10 & -.08 & .00 & .32 & 26.93 \\
\hline 1997 & 37.41 & .82 & 17.77 & -4.35 & .14 & .01 & .37 & 24.29 \\
\hline 1998 & 44.65 & .78 & 18.02 & -.04 & .08 & .01 & .30 & 27.06 \\
\hline 1999 & 48.11 & .71 & 17.24 & 2.39 & -.05 & .02 & .29 & 28.93 \\
\hline 2000 & 47.46 & .79 & 22.01 & .18 & .05 & .02 & .30 & 25.69 \\
\hline 2001 & 36.43 & .80 & 15.41 & -3.37 & -.12 & .02 & .30 & 24.99 \\
\hline Average & 46.89 & 0.68 & 21.58 & -0.11 & -0.01 & 0.00 & 0.23 & 25.88 \\
\hline
\end{tabular}

${ }^{1}$ Dry year.

${ }^{2}$ Average year.

${ }^{3}$ Wet year.

(GWW) ranged from 0.14 in. in 1984 to 0.40 in. in 2000 and averaged 0.25 in. (table 3 ). Ground-water withdrawals generally increased from 1977 to 2001 (fig. 4).

Recharge of water to the ground-water system (GWR) by golf courses and land-application sewage-treatment systems ranged from 0.04 for 1977-85 to 0.13 in. in 1997 and 2000 and averaged 0.08 in. (table 3). Data for some small dischargers were available for only 1 year (generally 1983, 1993, or 1997); discharge was assumed to be constant during all years. All small discharges were less than $0.001 \mathrm{Mgal} / \mathrm{d}$.

Surface-water withdrawals (SWW) ranged from $0.43 \mathrm{in}$. in 1984 to 0.85 in 1994 and averaged 0.58 in. Surface-water withdrawals generally increased from 1977 to 2001 (fig. 4). The Downingtown Municipal Authority and Sunoco Products Company make the major withdrawals of surface water in the watershed. Surface-water discharge is discharge to the stream from water that was withdrawn, but was not consumed. More water 
Table 3. Water-use budget for the East Branch Brandywine Creek watershed, Chester County, Pennsylvania, 1977-2001.

[All units are given in inches]

\begin{tabular}{|c|c|c|c|c|c|c|c|c|}
\hline Year & $\begin{array}{c}\text { Imported } \\
\text { water (IMP) }\end{array}$ & $\begin{array}{l}\text { Ground-water } \\
\text { withdrawals } \\
\text { (GWW) }\end{array}$ & $\begin{array}{c}\text { Ground-water } \\
\text { exports } \\
\text { (GWEXP) }\end{array}$ & $\begin{array}{c}\text { Returns to } \\
\text { ground } \\
\text { water (GWR) }\end{array}$ & $\begin{array}{c}\text { Surface-water } \\
\text { withdrawals } \\
\text { (SWW) }\end{array}$ & $\begin{array}{l}\text { Discharge to } \\
\text { surface } \\
\text { water (SWD) }\end{array}$ & $\begin{array}{l}\text { Consumptive use } \\
\text { (CON) }\end{array}$ & $\begin{array}{l}\text { Residual } \\
\text { (RES) }\end{array}$ \\
\hline 1977 & 0.31 & 0.22 & 0.00 & 0.04 & 0.49 & 0.86 & 0.16 & -0.04 \\
\hline 1978 & .44 & .23 & .00 & .04 & .48 & .97 & .16 & -.02 \\
\hline 1979 & .50 & .23 & .00 & .04 & .53 & 1.05 & .19 & -.02 \\
\hline${ }^{1} 1980$ & .39 & .23 & .00 & .04 & .53 & .96 & .17 & -.02 \\
\hline 1981 & .43 & .18 & .00 & .04 & .54 & .96 & .17 & -.02 \\
\hline 1982 & .51 & .17 & .00 & .04 & .51 & 1.00 & .17 & -.02 \\
\hline 1983 & .68 & .15 & .00 & .04 & .49 & 1.10 & .19 & -.01 \\
\hline 1984 & .82 & .14 & .00 & .04 & .43 & 1.18 & .18 & -.01 \\
\hline 1985 & .58 & .15 & .00 & .04 & .61 & 1.10 & .21 & -.01 \\
\hline 1986 & .61 & .18 & .00 & .06 & .56 & 1.10 & .21 & -.02 \\
\hline 1987 & .57 & .19 & .00 & .06 & .51 & 1.05 & .18 & -.02 \\
\hline${ }^{2} 1988$ & .61 & .23 & .00 & .07 & .56 & 1.14 & .21 & -.02 \\
\hline 1989 & .83 & .25 & .00 & .08 & .53 & 1.32 & .24 & -.03 \\
\hline 1990 & .76 & .29 & .00 & .09 & .56 & 1.30 & .25 & -.03 \\
\hline 1991 & .77 & .29 & .00 & .09 & .59 & 1.32 & .26 & -.02 \\
\hline 1992 & .79 & .25 & .00 & .10 & .55 & 1.25 & .25 & -.01 \\
\hline 1993 & .93 & .25 & .00 & .10 & .54 & 1.38 & .26 & -.02 \\
\hline 1994 & .49 & .24 & .00 & .12 & .85 & 1.22 & .28 & -.04 \\
\hline 1995 & .86 & .23 & .00 & .11 & .60 & 1.35 & .26 & -.03 \\
\hline${ }^{3} 1996$ & 1.23 & .29 & .00 & .12 & .65 & 1.76 & .32 & -.03 \\
\hline 1997 & .82 & .34 & .01 & .13 & .71 & 1.41 & .37 & -.05 \\
\hline 1998 & .78 & .36 & .01 & .12 & .68 & 1.43 & .30 & -.04 \\
\hline 1999 & .71 & .36 & .02 & .12 & .66 & 1.35 & .29 & -.05 \\
\hline 2000 & .79 & .40 & .02 & .13 & .66 & 1.44 & .30 & -.04 \\
\hline 2001 & .80 & .37 & .02 & .12 & .66 & 1.44 & .30 & -.05 \\
\hline Average & 0.68 & 0.25 & 0.01 & 0.08 & 0.58 & 1.22 & 0.23 & -0.03 \\
\hline
\end{tabular}

${ }^{1}$ Dry year.

${ }^{2}$ Average year.

${ }^{3}$ Wet year. 
was discharged to East Branch Brandywine Creek than was withdrawn from it; this difference resulted in a net increase in streamflow. Discharge of water to East Branch Brandywine Creek (SWD) ranged from 0.86 in. in 1977 to 1.76 in. in 1996 and averaged 1.22 in. (table 3 ). Surface-water discharges generally increased from 1977 to 2001 (fig. 4). The largest dischargers were the Downingtown Area Regional Authority and Sunoco Products Company.

The residual (RES), which is the difference between sources and destinations of water, was 0.05 in. or less and averaged $0.03 \mathrm{in}$. (table 3 ). The average residual is only 2 percent of the sum of the averages of the sources $(\mathrm{GWW}+\mathrm{SWW}+\mathrm{IMP})$ and may represent error in measurement or overestimated consumptive use.

Years representing dry, average, and wet years were chosen from the water budgets presented in table 2.1980 represents a dry year. Precipitation in 1980 was 11.48 in. less than the 25 -year average for the annual water budgets. The watershed lost 3.31 in. from ground-water storage. However, the previous year (1979) had above-average precipitation, and ground-water storage increased. Drainage of this stored ground water to the stream as base flow kept streamflow higher than would be expected in 1980. 1980 was followed by a second year with below-average precipitation, and streamflow for 1981 was the lowest of the 25 years from 1977 to 2001 . The estimated ET in 1980 was 23.24 in. and was 2.64 in. below the 25 -year average.

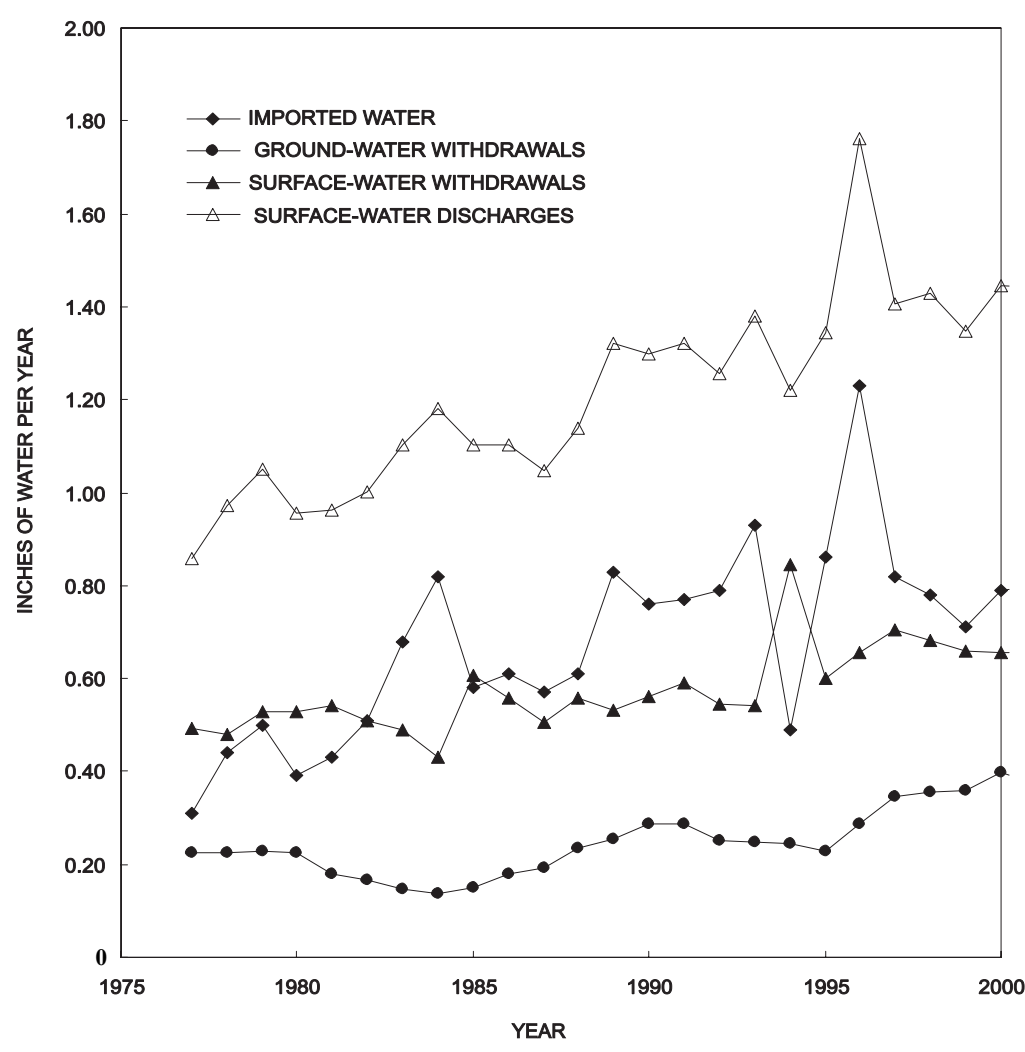

Figure 4. Surface-water withdrawals and discharges, ground-water withdrawals, and imported water in the East Branch Brandywine Creek watershed, Chester County, Pennsylvania, 1977-2001.
1988 represents an average year. Precipitation and streamflow were nearly the same as the 25 -year average. The estimated ET in 1988 was 26.64 in. and was 0.76 in. greater than the 25-year average.

1996 represents a wet year. Precipitation in 1996 was 22.45 in. greater than the 25-year average. Streamflow in 1996 was the highest for the period 1977-2001 and was $19.72 \mathrm{in.}$ above the 25-year average. Ground-water storage in 1996 increased by $2.10 \mathrm{in}$. The estimated ET was $26.93 \mathrm{in}$., which was 1.05 in. greater than the average ET. The ET was higher in other years with less rainfall. This may be caused by climatic differences, such as a cooler summer or different precipitation distributions, and by errors in measuring or estimating the other water-budget components.

The hydrograph from streamflow-gaging station East Branch Brandywine Creek below Downingtown, Pa., was separated into base-flow and surface-runoff components by the local minimum method of the HYSEP hydrograph-separation computer program (Sloto and Crouse, 1996). Base flow is sustained flow of a stream in the absence of direct runoff and includes natural and human-induced streamflows (U.S. Geological Survey, 2002). The record at this station is affected by outflow from the Marsh Creek Reservoir and by surface-water withdrawals and discharges. Because a water budget was available for the East Branch Brandywine Creek (table 2), the effects of the Marsh Creek Reservoir and surface-water withdrawals and discharges on base flow could be estimated.

The water budget (table 3) shows that more water was discharged to East Branch Brandywine Creek than was withdrawn from it, which resulted in a net increase in streamflow. To determine the quantity of water added to streamflow from outside the watershed, SWW was subtracted from SWD, and this quantity was subtracted from the base flow. Discharge from a reservoir generally is steady, and the HYSEP program interprets it as base flow. The discharge from the Marsh Creek Reservoir is measured by streamflow-gaging station Marsh Creek near Downingtown, Pa. (01480685) (fig. 3), which is directly downstream from the reservoir. The streamflow hydrograph from the Marsh Creek station was separated into direct-runoff and base-flow components. The drainage-area weighted base flow at the Marsh creek station was subtracted from the drainage-area-weighted base flow at the East Branch Brandywine Creek below Downingtown station to remove the contribution from the Marsh Creek Reservoir. The adjusted base flow at the East Branch Brandywine Creek below Downingtown station ranged from 6.56 in. in 1981 to 21.93 in. in 1996, and averaged $12.91 \mathrm{in}$. (table 4). Base flow made up 53.1 to 73.8 percent of streamflow and averaged 60.9 percent. The adjusted base flow ranged from 0.51 to $1.94 \mathrm{in.} \mathrm{less} \mathrm{than} \mathrm{the} \mathrm{unadjusted} \mathrm{base} \mathrm{flow} \mathrm{and} \mathrm{averaged}$ $1 \mathrm{in.} \mathrm{less} \mathrm{for} \mathrm{1977-2001.} \mathrm{The} \mathrm{difference} \mathrm{ranged} \mathrm{from} 4.4$ to 10.0 percent less than unadjusted base flow and averaged 7.2 percent less for 1977-2001 (table 4). On average, 67 percent of the difference was caused by sewage- 
treatment-plant and industrial discharges, and 33 percent was caused by regulation by the Marsh Creek Reservoir.

The East Branch Brandywine Creek watershed is a rural watershed underlain with reservoir storage that is UNDERLAIN by fractured rock. The watershed area is undergoing a transition from rural to suburban. Some water was imported into the watershed for public-water supply and as wastewater for treatment and discharge; these imports resulted in a net gain of water to the watershed. Because of a large regional sewage treatment plant, more water was discharged to East Branch Brandywine Creek than was withdrawn from it; this discharge caused an increase in streamflow. Most ground water was with- drawn for public-water supply. Surface water was withdrawn for public-water and industrial supply. Discharge of water by sewage-treatment plants and industries and regulation by Marsh Creek Reservoir caused base flow to appear higher than it would have been without these additional sources. Water imports, withdrawals, and discharges have been increasing over time as the watershed becomes more urbanized.

Table 4. Base flow for the streamflow-gaging station East Branch Brandywine Creek below Downingtown, Pennsylvania, $1977-2001$.

[All quantities given in inches]

\begin{tabular}{|c|c|c|c|c|c|c|c|c|}
\hline Year & $\begin{array}{l}\text { Unadjusted } \\
\text { base flow }\end{array}$ & $\begin{array}{l}\text { Percentage of } \\
\text { unadjusted } \\
\text { base flow as } \\
\text { streamflow }\end{array}$ & $\begin{array}{l}\text { Increase in base } \\
\text { flow from } \\
\text { surface-water } \\
\text { discharge }\end{array}$ & $\begin{array}{l}\text { Change in } \\
\text { base flow from } \\
\text { Marsh Creek } \\
\text { Reservoir }\end{array}$ & $\begin{array}{l}\text { Adjusted } \\
\text { base } \\
\text { flow }\end{array}$ & $\begin{array}{c}\text { Difference } \\
\text { between } \\
\text { unadjusted and } \\
\text { adjusted base } \\
\text { flow }\end{array}$ & $\begin{array}{c}\text { Percent } \\
\text { difference between } \\
\text { unadjusted and } \\
\text { adjusted base flow }\end{array}$ & $\begin{array}{c}\text { Percentage of } \\
\text { adjusted base } \\
\text { flow as } \\
\text { streamflow }\end{array}$ \\
\hline 1977 & 13.05 & 63.7 & 0.37 & 0.36 & 12.32 & 0.73 & 5.6 & 60.1 \\
\hline 1978 & 19.01 & 64.1 & .49 & .71 & 17.81 & 1.20 & 6.3 & 60.1 \\
\hline 1979 & 20.83 & 60.8 & .52 & .98 & 19.33 & 1.50 & 7.2 & 56.4 \\
\hline 1980 & 12.07 & 77.8 & .43 & .19 & 11.45 & .62 & 5.1 & 73.8 \\
\hline 1981 & 7.07 & 72.5 & .42 & .09 & 6.56 & .51 & 7.2 & 67.4 \\
\hline 1982 & 12.38 & 60.2 & .49 & .60 & 11.29 & 1.09 & 8.8 & 54.9 \\
\hline 1983 & 17.81 & 57.5 & .61 & -.62 & 16.58 & 1.23 & 6.9 & 53.6 \\
\hline 1984 & 20.92 & 62.8 & .75 & .93 & 19.24 & 1.68 & 8.0 & 57.8 \\
\hline 1985 & 9.34 & 61.8 & .50 & .25 & 8.60 & .74 & 7.9 & 57.0 \\
\hline 1986 & 12.31 & 67.4 & .55 & .25 & 11.52 & .79 & 6.4 & 63.1 \\
\hline 1987 & 12.30 & 68.3 & .54 & 0 & 11.76 & .54 & 4.4 & 65.3 \\
\hline 1988 & 14.02 & 66.2 & .58 & .26 & 13.18 & .84 & 6.0 & 62.2 \\
\hline 1989 & 16.42 & 63.6 & .79 & .39 & 15.24 & 1.18 & 7.2 & 59.0 \\
\hline 1990 & 13.32 & 67.5 & .74 & .06 & 12.52 & .80 & 6.0 & 63.4 \\
\hline 1991 & 11.70 & 71.4 & .73 & .11 & 10.86 & .84 & 7.2 & 66.3 \\
\hline 1992 & 9.79 & 67.7 & .71 & .09 & 9.00 & .79 & 8.1 & 62.3 \\
\hline 1993 & 15.57 & 59.5 & .84 & .35 & 14.38 & 1.19 & 7.6 & 54.9 \\
\hline 1994 & 14.69 & 63.3 & .38 & .67 & 13.65 & 1.04 & 7.1 & 58.8 \\
\hline 1995 & 9.49 & 63.9 & .74 & .16 & 8.58 & .91 & 9.6 & 57.8 \\
\hline 1996 & 23.87 & 57.8 & 1.11 & .83 & 21.93 & 1.94 & 8.1 & 53.1 \\
\hline 1997 & 13.48 & 75.8 & .70 & .02 & 12.76 & .72 & 5.3 & 71.8 \\
\hline 1998 & 12.08 & 67.0 & .75 & .40 & 10.93 & 1.15 & 9.5 & 60.7 \\
\hline 1999 & 10.62 & 61.6 & .69 & .37 & 9.56 & 1.06 & 10.0 & 55.5 \\
\hline 2000 & 14.04 & 63.8 & .79 & .23 & 13.03 & 1.01 & 7.2 & 59.2 \\
\hline 2001 & 11.44 & 74.2 & .79 & .07 & 10.59 & .85 & 7.4 & 68.7 \\
\hline Average & 13.90 & 65.6 & 0.64 & 0.36 & 12.91 & 1.00 & 7.2 & 60.9 \\
\hline
\end{tabular}




\section{Wissahickon Creek Watershed}

The 64-mi ${ }^{2}$ Wissahickon Creek watershed in Montgomery and Philadelphia Counties, Pa., represents an urban fracturedrock watershed (fig. 5). The Wissahickon Creek watershed includes USGS streamflow-gaging station Wissahickon Creek at Mouth, Philadelphia, Pa. (station 01474000), which was used to calculate the streamflow term in the water budgets. The Wissahickon Creek watershed is highly urbanized, and substantial quantities of water are transferred in and out of the basin. Nearly all of the residents of the watershed are served by public-water and sewer systems.

The period for which annual water budgets were calculated (1987-98) was governed by the availability of water-use data. For the Wissahickon Creek watershed, the following equation was used to calculate the basin water budget:

$$
\mathrm{P}+\mathrm{IMP}=\mathrm{SF} \quad \Delta \mathrm{GWS}+\mathrm{GWEXP}+\mathrm{CON}+\mathrm{ET} .
$$

The basin water-budget equation (eq. 5) was adjusted for conditions in the Wissahickon Creek watershed. This watershed does not have surface-water impoundments, surface-water exports, or leakage to underlying confined units; therefore, those terms are not included in equation 10.

Water budgets for the Wissahickon Creek watershed are presented for 1987-98 in table 5. The ET term, which includes evapotranspiration plus all errors in measurement or estimation of the other water-budget terms, ranged from 18.03 in. in 1996 to $30.44 \mathrm{in}$. in 1989 and averaged $23.12 \mathrm{in}$. The average annual potential ET estimated by Jenner and Lins (1991, p. 100) for the Wissahickon Creek watershed is about 28 to $29 \mathrm{in}$.

Digital precipitation data were available from three NOAA precipitation gages: Conshohocken (1948-2001), Norristown (1948-87 and 2001), and Willow Grove Naval Air Station (1967-2001) (fig. 5). None of the precipitation gages are in the watershed. Two Thiessen polygon nets were created corresponding to two sets of precipitation-gage locations: 1987 and 1988-98. For each Thiessen polygon net, weights were determined for each station, and an annual precipitation for the watershed was calculated. The Willow Grove precipitation gage, which is just east of the watershed, received the most weight (68 percent). Annual precipitation ( $\mathrm{P}$ ) ranged from $35.21 \mathrm{in}$. in 1997 to $62.93 \mathrm{in}$. in 1996 and averaged $47.23 \mathrm{in.}$ (table 5).

Data from the USGS streamflow-gaging station Wissahickon Creek at Mouth, Philadelphia, Pa., was used to calculate the streamflow component of the water budgets. Streamflow (SF) ranged from 14.95 in. in 1992 to 40.68 in. in 1996 and averaged $22.24 \mathrm{in}$. (table 5).

No long-term ground-water-level data are available for the watershed. The annual change in ground-water storage was estimated on the basis of records from the nearest USGS long-term observation well, DE-723, which is outside the watershed (fig. 5). The annual change in water level in well DE-723 was multiplied by a specific yield of 0.08 to calculate the change in ground-water storage. The estimated annual change in ground- water storage ( $\Delta$ GWS) ranged from a loss of $3.91 \mathrm{in.}$ in 1997, the driest year, to a gain of 3 in. in 1996, the wettest year, and averaged -0.15 in. (table 5).

Nearly all the Wissahickon Creek watershed is served by public-water and sewer systems. In some parts of the watershed, all water is imported from outside sources through water-supply lines, and all wastewater is exported through sewer lines for treatment outside the watershed. The quantity of this water is not considered in the water budget. In other parts of the watershed, water is pumped locally and exported from the watershed, or used locally and then exported as wastewater for treatment outside the watershed. In some parts of the watershed, water is imported from outside sources through water-supply lines, and wastewater is treated and discharged in the watershed. A GIS analysis that combined water and sewer service areas with water-use data was used to determine imported and exported water. For service areas with a source of water outside the basin and discharge within the basin, water was considered to be imported. For service areas with a source of water inside the basin and discharge outside the basin, water was considered to be exported. The quantity of imported water (IMP) ranged from $1.45 \mathrm{in.}$ in 1998 to $1.95 \mathrm{in.}$ in 1996 and averaged $1.64 \mathrm{in.}$ (table 5). The quantity of exported ground water (GWEXP) ranged from $1.65 \mathrm{in}$. in 1996, the wettest year, to $1.94 \mathrm{in}$. in 1987 and averaged 1.78 in. (table 5, fig. 6). Exports of water from the watershed exceeded imports for all years except 1993-94 and 1996 (fig. 6). Annual exports exceeded imports by 0.08 to 0.46 in. Imports and exports of water remained fairly steady for 1987-90 (fig. 6).

Consumptive water use was estimated from the data provided by the DRBC. If discharge data were not available for industries and public supply, consumptive use was assumed to be 10 percent of withdrawals. If discharge data were available for industries and public supply, consumptive use was estimated as the difference between ground-water withdrawal and discharge. If recharge data were available for golf courses, consumptive use was assumed to be the difference between withdrawals and discharge plus recharge. If recharge data were not available for golf courses, recharge was assumed to be 10 percent of withdrawals. Estimated consumptive use (CON) ranged from $0.80 \mathrm{in}$. in 1987 to $2.88 \mathrm{in}$. in 1998 and averaged $1.88 \mathrm{in.}$ (table 5). The large difference from year to year probably results from missing and estimated water-use data.

For the Wissahickon Creek watershed, the following equation was used to calculate the water-use budget:

$$
\begin{array}{r}
\mathrm{IMP}+\mathrm{GWW}+\mathrm{QGWW}-\mathrm{GWEXP} \\
-\mathrm{GWR}+\mathrm{SWW}-\mathrm{SWD}-\mathrm{CON}=\mathrm{RES} .
\end{array}
$$

The water-use budget equation (eq. 7) was adjusted for conditions in the Wissahickon Creek watershed. This watershed does not have surface-water exports; therefore, that term is not included in equation 11. Water-use budgets for the Wissahickon Creek watershed for 1987-98 are presented in table 6.

Ground-water-withdrawal, surface-water-withdrawal, and discharge data were provided by the DRBC. Ground-water and 


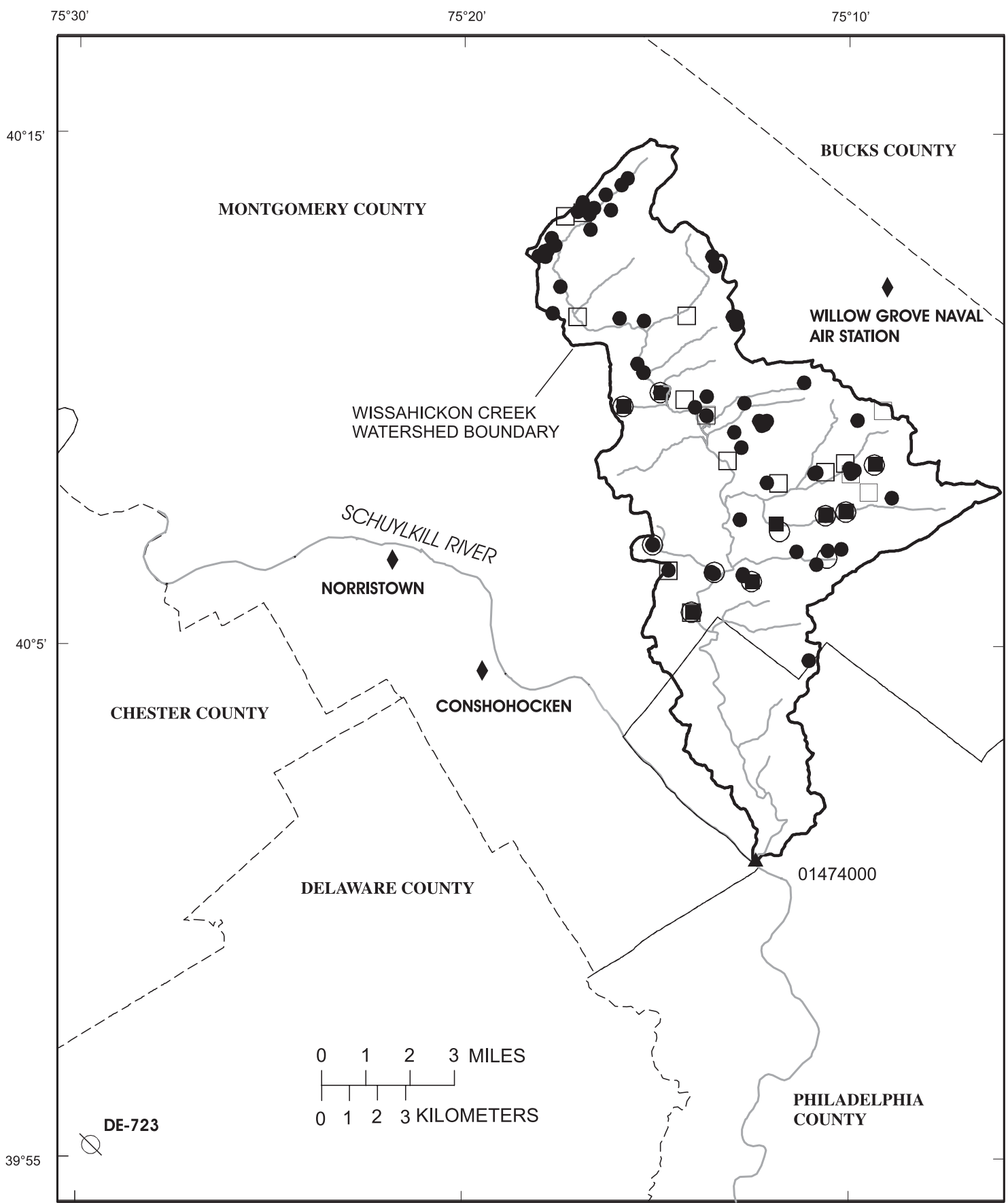

Base from U.S. Geological Survey digital data, 1972, 1:2,000,000 Albers Equal-Area Conicprojection Standard parallels $29^{\circ} 30^{\prime} \mathrm{N}$ and $45^{\circ} 30^{\prime} \mathrm{N}$, central meridian $75^{\circ} 00^{\prime} \mathrm{W}$

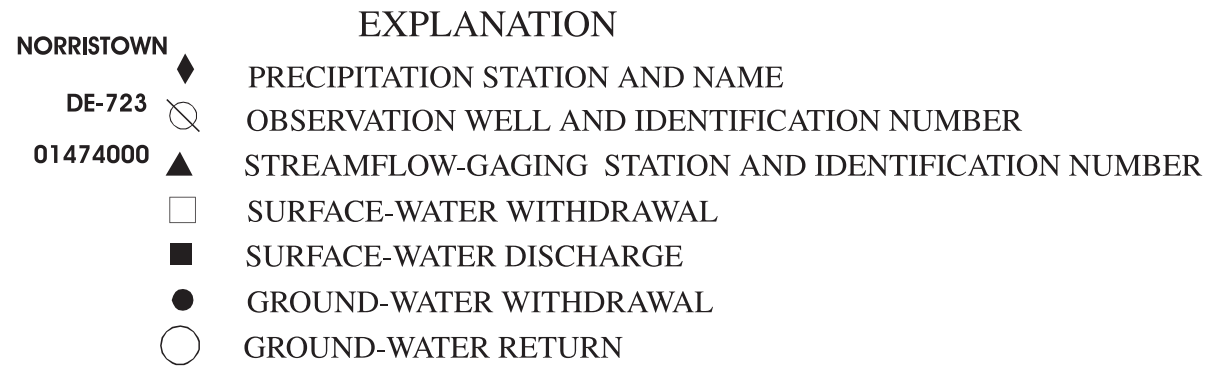

Figure 5. Wissahickon Creek watershed, Montgomery and Philadelphia Counties, Pennsylvania. Location of watershed shown on figure 1. 
Table 5. Basin water budget for the Wissahickon Creek watershed, Montgomery and Philadelphia Counties, Pennsylvania, 1987-98.

[All units are given in inches]

\begin{tabular}{cccccccc}
\hline Year & $\begin{array}{c}\text { Precipitation } \\
\text { (P) }\end{array}$ & $\begin{array}{c}\text { Imported } \\
\text { water } \\
\text { (IMP) }\end{array}$ & $\begin{array}{c}\text { Streamflow } \\
\text { (SF) }\end{array}$ & $\begin{array}{c}\text { Change in } \\
\text { ground-water } \\
\text { storage } \\
\text { (\$GWS) }\end{array}$ & $\begin{array}{c}\text { Ground-water } \\
\text { exports } \\
\text { (GWEX) }\end{array}$ & $\begin{array}{c}\text { Consumptive } \\
\text { use } \\
\text { (CON) }\end{array}$ & $\begin{array}{c}\text { Evapotranspiration } \\
\text { (ET) } \\
\text { and errors }\end{array}$ \\
\hline 1987 & 40.11 & 1.48 & 20.97 & -0.70 & 1.94 & 0.80 & 18.58 \\
11988 & 47.92 & 1.63 & 20.71 & .13 & 1.88 & 2.88 & 23.95 \\
1989 & 59.80 & 1.66 & 27.74 & .15 & 1.85 & 1.28 & 30.44 \\
1990 & 51.05 & 1.57 & 21.83 & 1.13 & 1.90 & 1.37 & 26.39 \\
1991 & 45.32 & 1.57 & 19.05 & -1.12 & 1.83 & 2.73 & 24.40 \\
1992 & 39.04 & 1.48 & 14.95 & 1.62 & 1.74 & 1.81 & 20.40 \\
1993 & 51.96 & 1.79 & 23.31 & -.95 & 1.74 & 2.45 & 27.20 \\
1994 & 51.81 & 1.85 & 23.56 & -.45 & 1.71 & 2.32 & 26.52 \\
1995 & 42.80 & 1.62 & 17.46 & -.28 & 1.71 & 2.49 & 23.04 \\
${ }^{2} 1996$ & 62.93 & 1.95 & 40.68 & 3.00 & 1.65 & 1.52 & 18.03 \\
${ }^{3} 1997$ & 35.21 & 1.59 & 17.64 & -3.91 & 1.67 & 1.85 & 19.55 \\
1998 & 38.87 & 1.45 & 18.96 & -.39 & 1.73 & 1.09 & 18.93 \\
& & & & & & & \\
Average & 47.23 & 1.64 & 22.24 & -0.15 & 1.78 & 1.88 & 23.12 \\
\hline
\end{tabular}

${ }^{1}$ Average year.

${ }^{2}$ Wet year.

${ }^{3}$ Dry year.

surface-water-withdrawal data were available for most users for most years. Data for some wells were available only for 1992-96. Missing data were interpolated or assumed to be the same as they were during the preceding or past year. Data for major water dischargers were available for 1992-2000. Data for small industrial dischargers were available only for 1993; discharge was assumed to be constant for all years. All small industrial discharges were less than $0.001 \mathrm{Mgal} / \mathrm{d}$.

Ground-water withdrawals for industrial and public-water supply (GWW) ranged from $2.76 \mathrm{in}$. in 1996-97 to $3.35 \mathrm{in}$. in 1988 and averaged 3.03 in. Ground-water withdrawals were fairly steady for 1989-98 (fig. 6). Major public water suppliers pumping wells in the watershed include Ambler Borough Water Department, Aqua Pennsylvania, Inc., North Penn Water Authority, and North Wales Water Authority. Ground water is pumped for quarry dewatering by Highway Materials, Inc. at their Plymouth Meeting quarry. Annual pumpage (QGWW) ranged from $1.45 \mathrm{in}$. in 1997, the driest year in the water budgets, to an estimated $3.4 \mathrm{in}$. in 1989-91 and averaged 2.90 in. (table 6). Ground-water withdrawals for quarry dewatering were fairly steady for 1987-98, except for 1997, which was a dry year (fig. 6). The pumped water is discharged to Wissahickon Creek. The estimated return of water to the ground-water system (GWR) by golf courses and septic systems is 0.01 to 0.02 in. (table 6).
Surface-water withdrawals (SWW) ranged from 0.05 in. in 1990 to 0.15 in. 1987-88 and averaged 0.09 in. (table 6). All surface-water withdrawals in the watershed are by golf courses. Discharge of water to Wissahickon Creek (SWD), which includes the discharge from the Plymouth Meeting quarry, ranged from 3.93 in. in 1997 to 5.94 in. in 1996, the wettest year, and averaged 5.30 in. (table 6). Discharge of water to Wissahickon Creek was fairly steady for 1987-98 (fig. 6) but higher in 1996, a wet year (fig. 6). The largest dischargers were the Plymouth Meeting quarry and sewage-treatment plants operated by Ambler Borough, Abington Township, and Upper Gywnned Township.

The residual (RES), which is the difference between sources (GWW + SWW + IMP) and destinations (GWEXP + GWR + SWD + CON), ranged from -0.18 in. to -2.03 in. and averaged -1.31 in. (table 6 ). The negative values indicate that more water was discharged and exported (destinations) than withdrawn and imported (sources). The residual ranged from 2.4 to 26.3 percent of the sources and averaged 17.4 percent. This range and average percentage indicates that the available data from the suppliers and dischargers do not account for all the imported and/or withdrawn water.

Years representing dry, average, and wet years were chosen from the water budgets presented in table 5.1997 represents a dry year. Precipitation in 1997 was 12.02 in. less than the 12- 


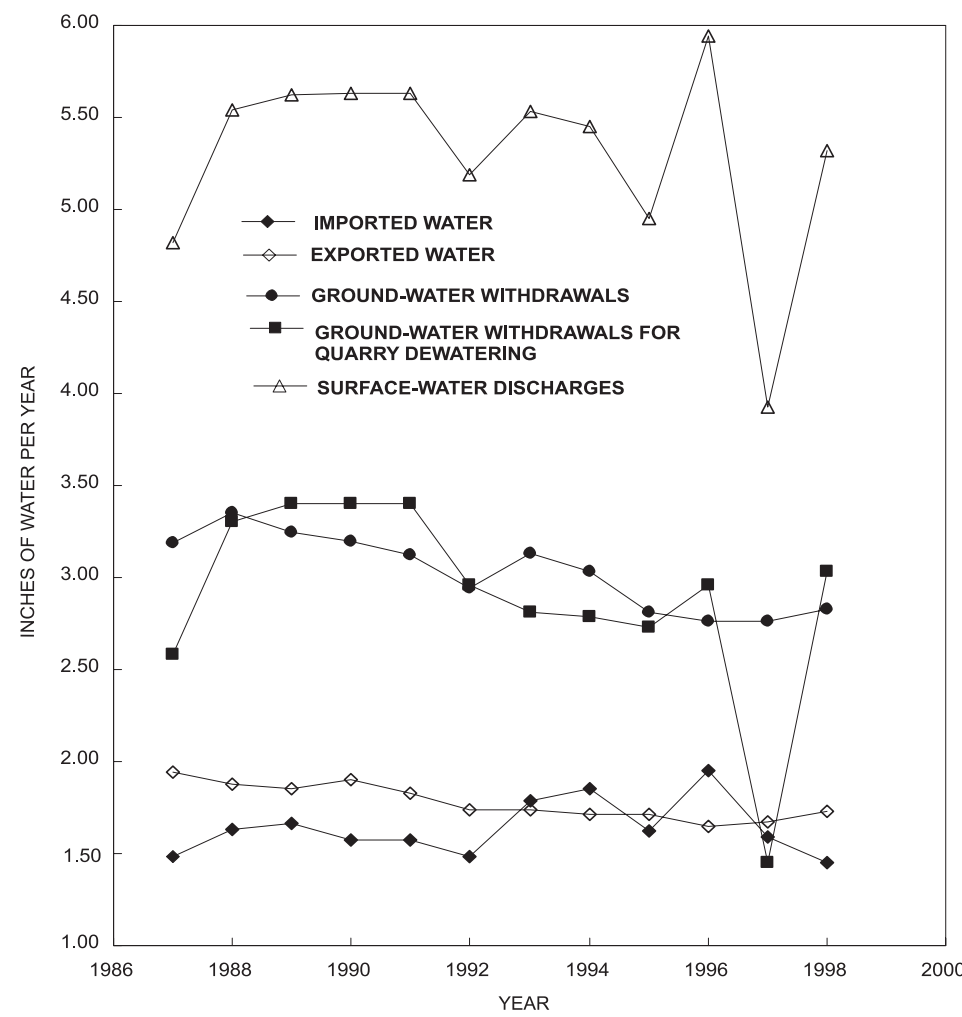

Figure 6. Surface-water discharges, ground-water withdrawals, and imported and exported water in the Wissahickon Creek watershed, Montgomery and Philadelphia Counties, Pennsylvania, 1987-98. year average for the annual water budgets. The watershed lost 3.91 in. of water from ground-water storage. In the previous wet year (1996), however, ground-water storage increased, and drainage of this stored ground water to the stream as base flow kept streamflow higher than it would have been otherwise in 1997. Streamflow for 1997 is the third lowest of the 12 years from 1987 to 1998 and was 4.60 in. less than the 12-year average. The estimated ET was $19.55 \mathrm{in}$. and was $3.57 \mathrm{in}$. less than the 12-year average.

1988 represents an average year. Precipitation in 1988 was 0.69 in. greater than the 12-year average. Streamflow was $1.53 \mathrm{in}$. less than the 12-year average. The estimated ET was 23.95 in. and was 0.83 in. greater than the 12 -year average.

1996 represents a wet year. Precipitation in 1996 was 15.70 in. greater than the 12-year average. Streamflow in 1996 was the highest for 1987-98 and was 18.44 in. above the 12-year average. Ground-water storage in 1996 increased by 3.00 in. The estimated ET was 18.03 in. and was 5.09 in. less than the 12-year average. The low ET probably results from error in the measurement of the other water-budget components.

The hydrograph from streamflow-gaging station Wissahickon Creek at Mouth, Philadelphia, Pa., was separated into base-flow and surface-runoff components by the local minimum method of the HYSEP computer program (Sloto and Crouse, 1996). The record at this station is greatly affected by discharges to surface water from quarry dewa-

Table 6. Water-use budget for the Wissahickon Creek watershed, Montgomery and Philadelphia Counties, Pennsylvania, 1987-98.

[All units are given in inches]

\begin{tabular}{|c|c|c|c|c|c|c|c|c|c|}
\hline Year & $\begin{array}{l}\text { Imported } \\
\text { water } \\
\text { (IMP) }\end{array}$ & $\begin{array}{l}\text { Ground-water } \\
\text { withdrawals } \\
\text { (GWW) }\end{array}$ & $\begin{array}{l}\text { Quarry ground- } \\
\text { water } \\
\text { withdrawals } \\
\text { (OGWW) }\end{array}$ & $\begin{array}{l}\text { Ground- } \\
\text { water } \\
\text { exports } \\
\text { (GWEXP) }\end{array}$ & $\begin{array}{c}\text { Recharge } \\
\text { to ground } \\
\text { water } \\
\text { (GWR) }\end{array}$ & $\begin{array}{c}\text { Surface-water } \\
\text { withdrawals } \\
\text { (SWW) }\end{array}$ & $\begin{array}{l}\text { Discharge to } \\
\text { surface water } \\
\text { (SWD) }\end{array}$ & $\begin{array}{c}\text { Consumptive } \\
\text { use } \\
\text { (CON) }\end{array}$ & $\begin{array}{c}\text { Residual } \\
\text { (RES) }\end{array}$ \\
\hline 1987 & 1.48 & 3.19 & 2.58 & 1.94 & 0.02 & 0.15 & 4.82 & 0.8 & -0.18 \\
\hline${ }^{1} 1988$ & 1.63 & 3.35 & 3.30 & 1.88 & .02 & .15 & 5.54 & 2.88 & -1.89 \\
\hline 1989 & 1.66 & 3.25 & 3.40 & 1.85 & .01 & .08 & 5.62 & 1.28 & -.37 \\
\hline 1990 & 1.57 & 3.20 & 3.40 & 1.90 & .01 & .05 & 5.63 & 1.37 & -.69 \\
\hline 1991 & 1.57 & 3.12 & 3.40 & 1.83 & .02 & .09 & 5.63 & 2.73 & -2.03 \\
\hline 1992 & 1.48 & 2.94 & 2.96 & 1.74 & .01 & .07 & 5.19 & 1.81 & -1.30 \\
\hline 1993 & 1.79 & 3.13 & 2.81 & 1.74 & .01 & .08 & 5.53 & 2.45 & -1.92 \\
\hline 1994 & 1.85 & 3.03 & 2.79 & 1.71 & .01 & .10 & 5.45 & 2.32 & -1.72 \\
\hline 1995 & 1.62 & 2.81 & 2.73 & 1.71 & .02 & .10 & 4.95 & 2.49 & -1.91 \\
\hline${ }^{2} 1996$ & 1.95 & 2.76 & 2.96 & 1.65 & .01 & .07 & 5.94 & 1.52 & -1.38 \\
\hline${ }^{3} 1997$ & 1.59 & 2.76 & 1.45 & 1.67 & .02 & .08 & 3.93 & 1.85 & -1.59 \\
\hline 1998 & 1.45 & 2.83 & 3.03 & 1.73 & .01 & .07 & 5.32 & 1.09 & -.77 \\
\hline Average & 1.64 & 3.03 & 2.90 & 1.78 & 0.01 & 0.09 & 5.30 & 1.88 & -1.31 \\
\hline
\end{tabular}

${ }^{1}$ Average year.

${ }^{2}$ Wet year.

${ }^{3}$ Dry year. 
tering and sewage-treatment plants. Because the outflow from the quarry and sewage-treatment plants usually is fairly constant, the HYSEP program interprets it as base flow. The base flow estimated by the HYSEP program was adjusted by subtracting the quarry and sewage-treatment-plant discharge. The result indicates that the apparent base flow at the streamflowgaging station, on average, was 56.3 percent ground-water discharge, 23.9 percent quarry discharge, and 19.8 percent sewage-treatment-plant discharge (table 7). The adjusted base flow made up 22.1 to 39.7 percent of streamflow and averaged 30.6 percent.

The Wissahickon Creek watershed is an urban watershed underlain by fractured rock. It is highly urbanized, and there is a complex system of interbasin water transfers. Water was imported into the basin for public-water supply and as wastewater for treatment and discharge. Ground water was exported from the watershed for public-water supply. More water was exported than imported; this difference resulted in a net loss of water from the watershed. Most ground-water withdrawal was for public and industrial supply, whereas most surface-water withdrawal was for golf-course irrigation. A quarry in the watershed pumped a substantial quantity of ground water for dewatering the quarry. Discharge of water by sewage-treatment plants, industries, and the quarry caused base flow at station Wissahickon Creek at Mouth to appear higher than it would have been without these additional sources and made up about 44 percent of the observed base flow. Water imports, exports, withdrawals, and discharges have been relatively steady over time.

\section{Pocono Creek Watershed}

The 46.5- $\mathrm{mi}^{2}$ Pocono Creek watershed in Monroe County, $\mathrm{Pa}$., is representative of a rural fractured-rock watershed (fig. 7). Most of the population of the watershed uses domestic wells and septic systems. Positioned 75 and $90 \mathrm{mi}$, respectively, from the New York and Philadelphia metropolitan regions, the natural resources of the Pocono Mountains are attractive. Whereas many homes are second homes that are used on weekends or in the summer or winter seasons, the year-round population is increasing. Many of the new residents of the Pocono Creek watershed work in the New York City metropolitan area.

The period for which annual water budgets were calculated (1975-2001) was governed by the available water-use data. Ground-water-withdrawal, surface-water-withdrawal, and discharge data were provided by the DRBC. The only withdrawal of surface water in the watershed was by the Camelback Ski Corporation for the Camelback Ski Area and Camelbeach Water Park. The major withdrawals of ground water in the watershed were by the Camelback Ski Corporation, Camelback Village, and Penn Estates Utilities, Inc. Surface-water withdrawal data are available for the Camelback Ski Corporation for 1975-2001, except for 1988, for which the data were estimated. Data for Penn Estates Utilities well 5 are available for 1990-99.

Table 7. Base flow for the streamflow-gaging station Wissahickon Creek at Mouth, Philadelphia, Pennsylvania, 1987-98.

[All quantities given in inches; STP, sewage-treatment plant]

\begin{tabular}{|c|c|c|c|c|c|c|c|c|}
\hline \multirow[b]{2}{*}{ Year } & \multirow[b]{2}{*}{ Streamflow } & \multirow[b]{2}{*}{$\begin{array}{l}\text { Unadjusted } \\
\text { base flow }\end{array}$} & \multirow[b]{2}{*}{$\begin{array}{l}\text { Unadjusted } \\
\text { base flow as a } \\
\text { percentage of } \\
\text { streamflow }\end{array}$} & \multirow[b]{2}{*}{$\begin{array}{c}\text { Adjusted base } \\
\text { flow }\end{array}$} & \multirow[b]{2}{*}{$\begin{array}{l}\text { Adjusted base } \\
\text { flow as a } \\
\text { percentage of } \\
\text { streamflow }\end{array}$} & \multicolumn{3}{|c|}{ Base flow } \\
\hline & & & & & & $\begin{array}{l}\text { Percentage } \\
\text { as ground- } \\
\text { water } \\
\text { discharge }\end{array}$ & $\begin{array}{c}\text { Percentage } \\
\text { as STP } \\
\text { discharge }\end{array}$ & $\begin{array}{c}\text { Percentage } \\
\text { as quarry } \\
\text { discharge }\end{array}$ \\
\hline 1987 & 20.97 & 12.43 & 59.3 & 7.61 & 36.3 & 61.2 & 18.1 & 36.3 \\
\hline 1988 & 20.71 & 10.78 & 52.1 & 5.24 & 25.3 & 48.6 & 20.8 & 25.3 \\
\hline 1989 & 27.74 & 14.16 & 51.0 & 8.54 & 30.8 & 60.3 & 15.7 & 30.8 \\
\hline 1990 & 21.83 & 12.42 & 56.9 & 6.79 & 31.1 & 54.7 & 18.0 & 31.1 \\
\hline 1991 & 19.05 & 10.45 & 54.8 & 4.82 & 25.3 & 46.1 & 21.3 & 25.3 \\
\hline 1992 & 14.95 & 8.49 & 56.8 & 3.30 & 22.1 & 38.9 & 26.4 & 22.1 \\
\hline 1993 & 23.31 & 12.08 & 51.8 & 6.55 & 28.1 & 54.2 & 22.6 & 28.1 \\
\hline 1994 & 23.56 & 13.65 & 57.9 & 8.20 & 34.8 & 60.1 & 19.5 & 34.8 \\
\hline 1995 & 17.46 & 10.92 & 62.5 & 5.97 & 34.2 & 54.7 & 20.4 & 34.2 \\
\hline 1996 & 40.68 & 17.77 & 43.7 & 11.83 & 29.1 & 66.6 & 16.8 & 29.1 \\
\hline 1997 & 17.64 & 10.93 & 62.0 & 7.00 & 39.7 & 64.0 & 22.8 & 39.7 \\
\hline 1998 & 18.96 & 11.22 & 59.2 & 5.90 & 31.1 & 52.6 & 20.5 & 31.1 \\
\hline Average & 22.24 & 12.11 & 54.5 & 6.81 & 30.6 & 56.3 & 19.8 & 23.9 \\
\hline
\end{tabular}




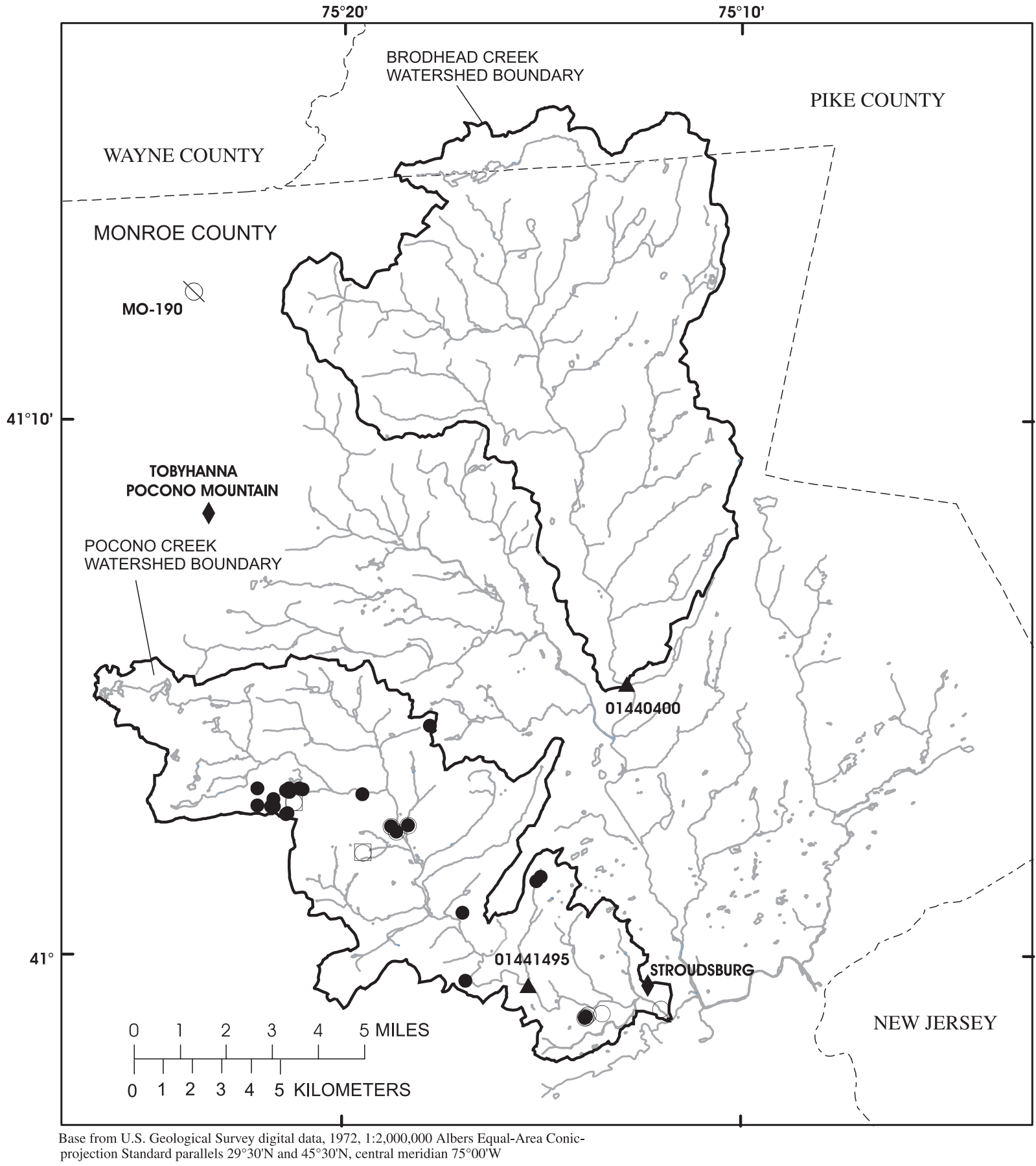

EXPLANATION

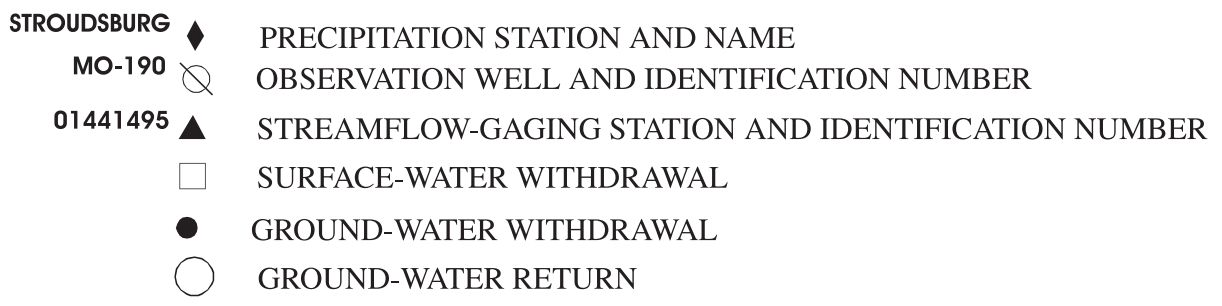

Figure 7. Pocono Creek watershed, Monroe County, Pennsylvania. Location of watershed shown on figure 1. 
All water pumped from this well is exported from the watershed. Withdrawal data for Camelback Village were estimated from Pennsylvania Department of Environmental Protection permit applications. Data for small commercial and industrial dischargers were available only for a single year; discharge for these users was assumed to be constant. These discharges are to septic systems, and all but one of the discharges were less than $0.001 \mathrm{Mgal} / \mathrm{d}$. There was no major discharge to surface water in the Pocono Creek watershed.

Because the Pocono Creek watershed was ungaged before June 2002, streamflow was estimated from data from nearby streamflow-gaging station Brodhead Creek near Analomink, Pa. (station number 01440400 , drainage area $65.9 \mathrm{mi}^{2}$, period of record 1957-current year) (fig. 7). Brodhead Creek near the Analomink station was chosen because of its similar drainagebasin size and geology. A regression equation for predicting the discharge at the Pocono Creek above Wigwam Run station was developed on the basis of the available daily discharge data for both stations at the time of the analysis (June 21, 2002 to February 8,2004$)$. A regression equation using all 570 available data points was used to predict the daily discharge at the Pocono Creek station. The differences between the measured and predicted discharges were ranked, and the difference was greater than 50 percent for 37 days; these points were removed from the data set. Most of these dates were in January and February when the records at the stations may have been affected by ice. A second regression equation was developed with the remaining 533 data points (fig. 8). The coefficient of determination $\left(\mathrm{R}^{2}\right)$ was 0.97 , and the standard error was $45 \mathrm{ft}^{3} / \mathrm{s}$. The second regression equation was then applied to the annual streamflow

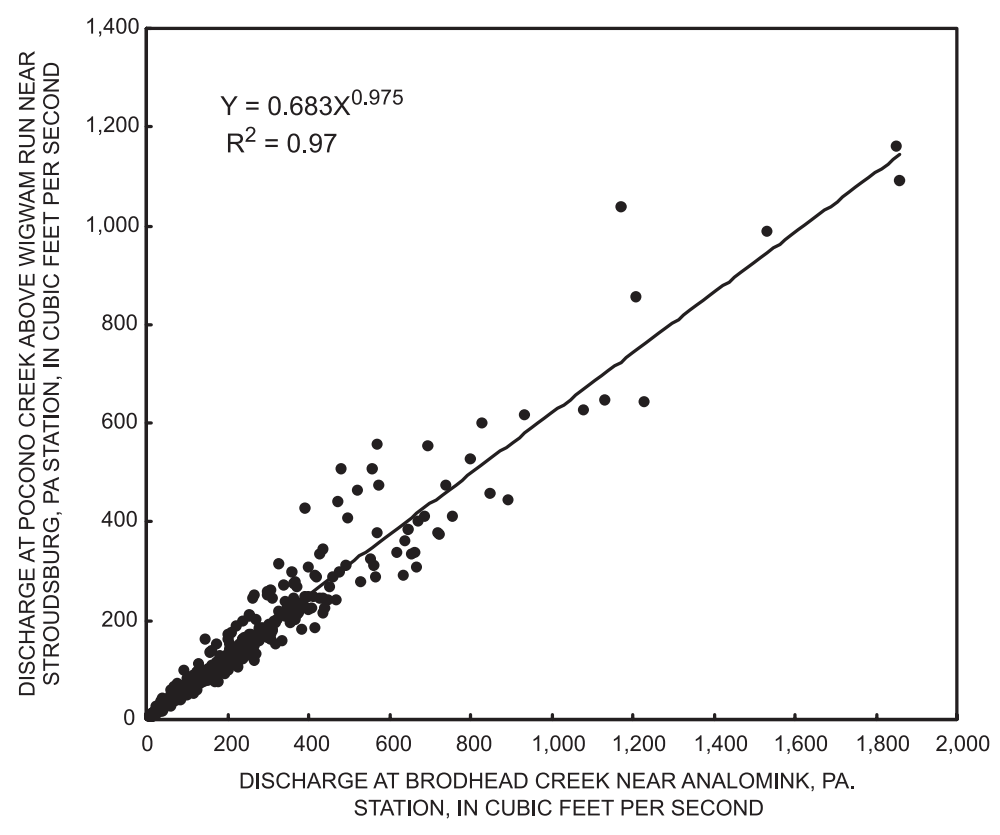

Figure 8. Relation between average daily discharge of Pocono Creek above Wigwam Run near Stroudsburg, Pennsylvania (01441495), and Brodhead Creek near Analomink, Pennsylvania (01440400), June 2002 to February 2004. at the Brodhead Creek station to estimate the annual streamflow for the Pocono Creek station. Estimated streamflow ranged from 14.66 in. in 2001 to 36.82 in. in 1996 and averaged 22.08 in. (table 8). A base-flow separation was not done for the Pocono Creek watershed because the streamflow was estimated.

For the Pocono Creek watershed, the following equation was used to calculate the basin water budget:

$$
\mathrm{P}=\mathrm{SF} \quad \Delta \mathrm{GWS}+\mathrm{GWEXP}+\mathrm{CON}+\mathrm{ET} .
$$

The basin water-budget equation (eq. 5) was adjusted for conditions in the Pocono Creek watershed. This watershed does not have imported water, surface-water impoundments, surfacewater exports, or leakage to underlying confined units; therefore, those terms are not included in equation 12.

Water budgets are presented for the Pocono Creek watershed for 1975-2001 in table 8. The ET term, which includes evapotranspiration plus all errors in measurement or estimation of the other water-budget terms, ranged from 21.31 in. in 1978 to 39.4 in. in 1998 and averaged 27.43 in. The estimated ET for 1998 is much higher than for the other years and probably is the result of estimating the streamflow record. The next highest ET values were $31.10 \mathrm{in}$. for 1983 and $31.06 \mathrm{in}$. for 1989, which represent a more realistic upper bound. The average annual potential ET estimated by Jenner and Lins (1991, p. 100) for the Pocono Creek watershed is about 25 to 26 in.

Digital precipitation data were available from two NOAA precipitation gages: Stroudsburg (1945-2001) and Tobyhanna Mount Pocono (1961-2001) (fig. 7). A Thiessen polygon net was created, weights were determined for each station, and an annual precipitation for the watershed was calculated. The Stroudsburg gage, near the mouth of the watershed received the most weight (76 percent). Annual precipitation $(\mathrm{P})$ ranged from 36.42 in. in 1980 to 66.52 in. in 1996 and averaged 49.70 in. (table 8).

No long-term ground-water-level data are available for the watershed. The change in ground-water storage was estimated on the basis of records from the nearest USGS long-term observation well, MO-190 (fig. 7). The annual change in water level in well MO-190 was multiplied by a specific yield of 0.04 to calculate the change in ground-water storage. The estimated annual change in ground-water storage ( $\triangle \mathrm{GWS}$ ) ranged from a loss of $3.01 \mathrm{in}$. in 1980 to a gain of $1.91 \mathrm{in.}$ in 1999 and averaged -0.05 in. (table 8).

Penn Estates Utilities, Inc. operates one well for public-water supply in the Pocono Creek watershed. All water withdrawn from this well is exported from the watershed. It is the only export of water from the watershed. Ground-water exports (GWEXP) ranged from 0.00 in. in 1975-89 to 0.57 in. in 1999-2001. Exports averaged 0.41 in. for 1990-2001, the period during which ground water was exported. Both ground-water withdrawals and exports have been increasing over time (fig. 9). 
Consumptive use (CON) for small industrial users was estimated as equal to 10 percent of withdrawals. Surface-water withdrawals by Camelback Ski Corporation have an estimated 22-percent consumptive-use rate (Delaware River Basin Commission, 2001), and, therefore, 78 percent of the water is assumed to return to the stream by snowmelt (SWD).

For the Pocono Creek watershed, the following equation was used to calculate the water-use budget:
GWW - GWEXP - GWR + SWW - SWD - CON = RES. (13)

The water-use budget equation (eq. 7) was adjusted for conditions in the Pocono Creek watershed. This watershed does not have imports, surface-water exports, or ground-water pumping for quarry operations; therefore, those terms are not included in equation 13. Water-use budgets for the Pocono Creek watershed for 1975-2001 are presented in table 9.

Table 8. Basin water budget for the Pocono Creek watershed, Monroe County, Pennsylvania, 1975-2001.

[All units are given in inches]

\begin{tabular}{|c|c|c|c|c|c|c|}
\hline Year & $\begin{array}{l}\text { Precipitation } \\
\text { (P) }\end{array}$ & $\begin{array}{l}\text { Streamflow } \\
\text { (SF) }\end{array}$ & 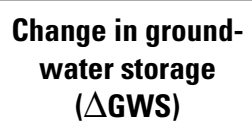 & $\begin{array}{l}\text { Ground-water } \\
\text { exports } \\
\text { (GWEXP) }\end{array}$ & $\begin{array}{c}\text { Consumptive } \\
\text { use } \\
\text { (CON) }\end{array}$ & $\begin{array}{c}\text { Evapotranspiration } \\
\text { (ET) } \\
\text { and errors }\end{array}$ \\
\hline 1975 & 56.60 & 26.74 & 0.13 & 0.00 & 0.02 & 29.71 \\
\hline 1976 & 51.44 & 27.13 & -.64 & .00 & .02 & 24.93 \\
\hline 1977 & 54.76 & 26.81 & .96 & .00 & .02 & 26.97 \\
\hline 1978 & 45.91 & 26.16 & -1.58 & .00 & .02 & 21.31 \\
\hline 1979 & 60.52 & 31.46 & 1.39 & .00 & .02 & 27.65 \\
\hline${ }^{1} 1980$ & 36.42 & 14.84 & -3.01 & .00 & .02 & 24.57 \\
\hline 1981 & 43.33 & 17.35 & 1.78 & .00 & .02 & 24.18 \\
\hline 1982 & 42.65 & 17.47 & -.18 & .00 & .03 & 25.33 \\
\hline 1983 & 62.41 & 29.70 & 1.59 & .00 & .02 & 31.10 \\
\hline${ }^{2} 1984$ & 49.15 & 23.50 & -1.96 & .00 & .04 & 27.57 \\
\hline 1985 & 39.61 & 16.70 & 1.44 & .00 & .04 & 21.43 \\
\hline 1986 & 54.05 & 23.91 & 1.03 & .00 & .03 & 29.08 \\
\hline 1987 & 50.10 & 24.77 & -.87 & .00 & .03 & 26.17 \\
\hline 1988 & 43.47 & 15.55 & -.60 & .00 & .03 & 28.49 \\
\hline 1989 & 52.47 & 21.81 & -.44 & .00 & .04 & 31.06 \\
\hline 1990 & 57.92 & 27.20 & 1.81 & .10 & .04 & 28.77 \\
\hline 1991 & 39.84 & 15.41 & -1.63 & .34 & .04 & 25.68 \\
\hline 1992 & 45.92 & 20.38 & 1.13 & .40 & .03 & 23.98 \\
\hline 1993 & 52.12 & 21.54 & -.25 & .31 & .05 & 30.47 \\
\hline 1994 & 52.82 & 27.00 & -.01 & .35 & .08 & 25.40 \\
\hline 1995 & 44.06 & 16.32 & -.52 & .33 & .08 & 27.85 \\
\hline${ }^{3} 1996$ & 66.52 & 36.82 & 1.53 & .45 & .07 & 27.65 \\
\hline 1997 & 41.01 & 15.26 & -1.53 & .47 & .08 & 26.73 \\
\hline 1998 & 59.59 & 21.23 & -1.63 & .51 & .08 & 39.40 \\
\hline 1999 & 49.97 & 17.84 & 1.91 & .57 & .08 & 29.57 \\
\hline 2000 & 45.54 & 18.64 & -.10 & .57 & .10 & 26.33 \\
\hline 2001 & 43.62 & 14.66 & -1.04 & .57 & .08 & 29.35 \\
\hline Average & 49.70 & 22.08 & -0.05 & 0.18 & 0.04 & 27.43 \\
\hline
\end{tabular}

${ }^{1}$ Dry year.

${ }^{2}$ Average year.

${ }^{3}$ Wet year. 


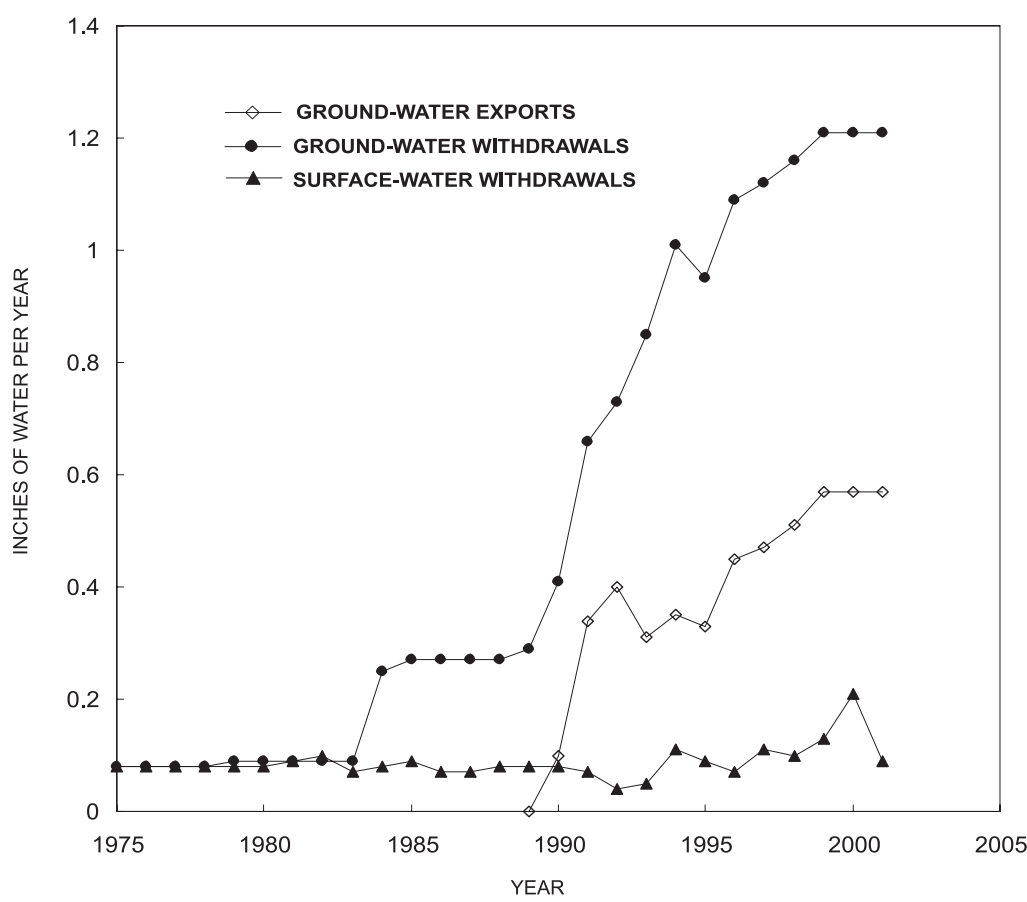

Figure 9. Surface-water and ground-water withdrawals and ground-water exports in the Pocono Creek watershed, Monroe County, Pennsylvania, 1975-2001.

Ground-water withdrawals (GWW) ranged from 0.08 in. in 1975-78 to $1.21 \mathrm{in}$. in 1999-2001 and averaged $0.52 \mathrm{in.}$ (table 9). Ground-water withdrawals have been increasing over time (fig. 9). Estimated discharge to ground water (GWR) through septic systems ranged from less than $0.01 \mathrm{in}$. in 1975-83 to 0.51 in. in 1994-2001 and averaged 0.22 in. Surfacewater withdrawals (SWW) by the Camelback Ski Corporation for snowmaking ranged from 0.04 in. in 1992 to 0.21 in. in 2000 and averaged 0.09 in. (table 9).

The residual (RES), which is the difference between sources (GWW + SWW) and destinations (GWR + GWEXP + $\mathrm{SWD}+\mathrm{CON}$ ) of water, ranged from $0.07 \mathrm{in}$. to $0.13 \mathrm{in}$. and averaged $0.11 \mathrm{in}$. (table 9). The residual ranged from 6.6 to 57.6 percent of the sources. The residual represents error in estimating GWR and CON.

Years representing dry, average, and wet years were chosen from the water budgets presented in table 8.1980 represents a dry year. Precipitation in 1980 was 13.28 in. less than the 27 -year average for the annual water budgets. The estimated streamflow was $7.24 \mathrm{in}$. less than the 27 -year average. The watershed lost $3.01 \mathrm{in}$. from ground-water storage in 1980. In the previous wet year (1979), however, ground-water storage increased, and drainage of this stored ground water to the stream as base flow probably kept streamflow higher than it would have been otherwise. The estimated ET in 1980 was $24.57 \mathrm{in}$., which is $2.86 \mathrm{in}$. less than the 27 -year average.

1984 represents an average year. Precipitation in 1984 was $0.55 \mathrm{in}$. less than the 27 -year average, and estimated streamflow was 1.42 in. greater than the 27 -year average. The estimated ET in 1984 was $27.57 \mathrm{in}$., which is 0.14 in. greater than the 27-year average.

1996 represents a wet year. Precipitation in 1996 was 16.82 in. greater than the 27 -year average. Estimated streamflow in 1996 was the highest for 19752001 and was 14.74 in. above the 27 -year average. Ground-water storage increased by $1.53 \mathrm{in}$. The estimated ET was 27.65 in., which is 0.22 in. greater than the 27-year average.

The Pocono Creek watershed is a rural watershed underlain by fractured rock. Some water was exported from the watershed for public-water supply. Most of the residents of the watershed relied on domestic wells and septic systems. Most of the nondomestic groundwater withdrawals and all of the surface-water withdrawals and discharges were for a ski resort. Water exports, withdrawals, and discharges have been increasing over time because of the growth of the ski resort and population increases in the Pocono Creek and surrounding watersheds.

\section{Coastal Plain-Aquifer Watersheds}

Annual water budgets were developed for two watersheds underlain by Coastal Plain sediments. The water budgets are for the unconfined aquifer system of each watershed. The watersheds are the Greenwood Branch of Rancocas Creek in south-central New Jersey and the Cooper River in southwestern New Jersey (fig. 1). The period covered by the water budgets, 1988-2002, was made the same for comparison of the watersheds and was determined by the date of regional sewering in the Cooper River watershed and the availability of water-use data.

\section{Greenwood Branch of the Rancocas Creek Watershed}

The 77.9- $\mathrm{mi}^{2}$ Greenwood Branch of the Rancocas Creek watershed in Burlington and Ocean Counties, N.J., above streamflow-gaging station Greenwood Branch at New Lisbon, N.J. (station number 01466900), represents a rural Coastal Plain watershed (fig. 10). The Greenwood Branch flows into the North Branch of Rancocas Creek just below station 01466900. Streamflow at North Branch Rancocas Creek at Pemberton, N.J. (station number 01467000), was used to represent the streamflow component of the water budget from 1988-2002 because of the limited period of record at the Greenwood Branch station. Thirty percent of the watershed is in Pemberton Township. The Pemberton Municipal Utility Authority provides water and sewer service to two-thirds of Pemberton Township, and the withdrawal wells are screened in the confined Wenonah-Mount Laurel aquifer. There are many domestic wells and septic systems in the watershed. Several cranberry growers and a sand-mining company are within this rural watershed. 
Ground-water-withdrawal (1990-1999), surface-waterwithdrawal (1990-1999), and surface-water-discharge (1999) data were provided by the DRBC. These data were supplemented for 1988-2002 with data from Pemberton Municipal Utility Authority, New Jersey Department of Environmental Protection Bureau of Water Allocation, the USGS Site Specific
Water-Use Data System (SWUDS), and the USGS Ground Water Site Inventory System (GWSI).

The following equation was used to calculate the basin water budget for the Greenwood Branch of Rancocas Creek watershed:

$$
\mathrm{P}=\mathrm{SF} \quad \Delta \mathrm{GWS} \mathrm{GWL}+\mathrm{SWEXP}+\mathrm{CON}+\mathrm{ET} .
$$

Table 9. Water-use budget for the Pocono Creek watershed, Monroe County, Pennsylvania, 1975-2001.

[All units are given in inches]

\begin{tabular}{|c|c|c|c|c|c|c|c|}
\hline Year & $\begin{array}{c}\text { Ground-water } \\
\text { withdrawals } \\
\text { (GWW) }\end{array}$ & $\begin{array}{l}\text { Ground-water } \\
\text { exports } \\
\text { (GWEXP) }\end{array}$ & $\begin{array}{l}\text { Returns to } \\
\text { ground water } \\
\text { (GWR) }\end{array}$ & $\begin{array}{l}\text { Surface-water } \\
\text { withdrawals } \\
\text { (SWW) }\end{array}$ & $\begin{array}{l}\text { Discharge to } \\
\text { surface water } \\
\text { (SWD) }\end{array}$ & $\begin{array}{l}\text { Consumptive } \\
\text { use } \\
\text { (CON) }\end{array}$ & $\begin{array}{c}\text { Residual } \\
\text { (RES) }\end{array}$ \\
\hline 1975 & 0.08 & 0.00 & 0.00 & 0.08 & 0.06 & 0.02 & 0.09 \\
\hline 1976 & .08 & .00 & .00 & .08 & .06 & .02 & .09 \\
\hline 1977 & .08 & .00 & .00 & .08 & .06 & .02 & .09 \\
\hline 1978 & .08 & .00 & .00 & .08 & .06 & .02 & .09 \\
\hline 1979 & .09 & .00 & .00 & .08 & .06 & .02 & .10 \\
\hline${ }^{1} 1980$ & .09 & .00 & .00 & .08 & .06 & .02 & .10 \\
\hline 1981 & .09 & .00 & .00 & .09 & .07 & .02 & .10 \\
\hline 1982 & .09 & .00 & .00 & .10 & .07 & .03 & .11 \\
\hline 1983 & .09 & .00 & .00 & .07 & .06 & .02 & .09 \\
\hline${ }^{2} 1984$ & .25 & .00 & .13 & .08 & .06 & .04 & .12 \\
\hline 1985 & .27 & .00 & .13 & .09 & .07 & .04 & .13 \\
\hline 1986 & .27 & .00 & .13 & .07 & .06 & .03 & .12 \\
\hline 1987 & .27 & .00 & .13 & .07 & .05 & .03 & .13 \\
\hline 1988 & .27 & .00 & .13 & .08 & .06 & .03 & .13 \\
\hline 1989 & .29 & .00 & .16 & .08 & .06 & .04 & .12 \\
\hline 1990 & .41 & .10 & .16 & .08 & .07 & .04 & .13 \\
\hline 1991 & .66 & .34 & .19 & .07 & .05 & .04 & .12 \\
\hline 1992 & .73 & .40 & .19 & .04 & .03 & .03 & .12 \\
\hline 1993 & .85 & .31 & .38 & .05 & .04 & .05 & .12 \\
\hline 1994 & 1.01 & .35 & .51 & .11 & .09 & .08 & .10 \\
\hline 1995 & .95 & .33 & .51 & .09 & .07 & .08 & .07 \\
\hline${ }^{3} 1996$ & 1.09 & .45 & .51 & .07 & .05 & .07 & .09 \\
\hline 1997 & 1.12 & .47 & .51 & .11 & .09 & .08 & .10 \\
\hline 1998 & 1.16 & .51 & .51 & .10 & .08 & .08 & .10 \\
\hline 1999 & 1.21 & .57 & .51 & .13 & .10 & .08 & .10 \\
\hline 2000 & 1.21 & .57 & .51 & .21 & .16 & .10 & .12 \\
\hline 2001 & 1.21 & .57 & .51 & .09 & .07 & .08 & .09 \\
\hline Average & 0.52 & 0.18 & 0.22 & 0.09 & 0.07 & 0.04 & 0.11 \\
\hline
\end{tabular}

${ }^{1}$ Dry year.

${ }^{2}$ Average year.

${ }^{3}$ Wet year. 


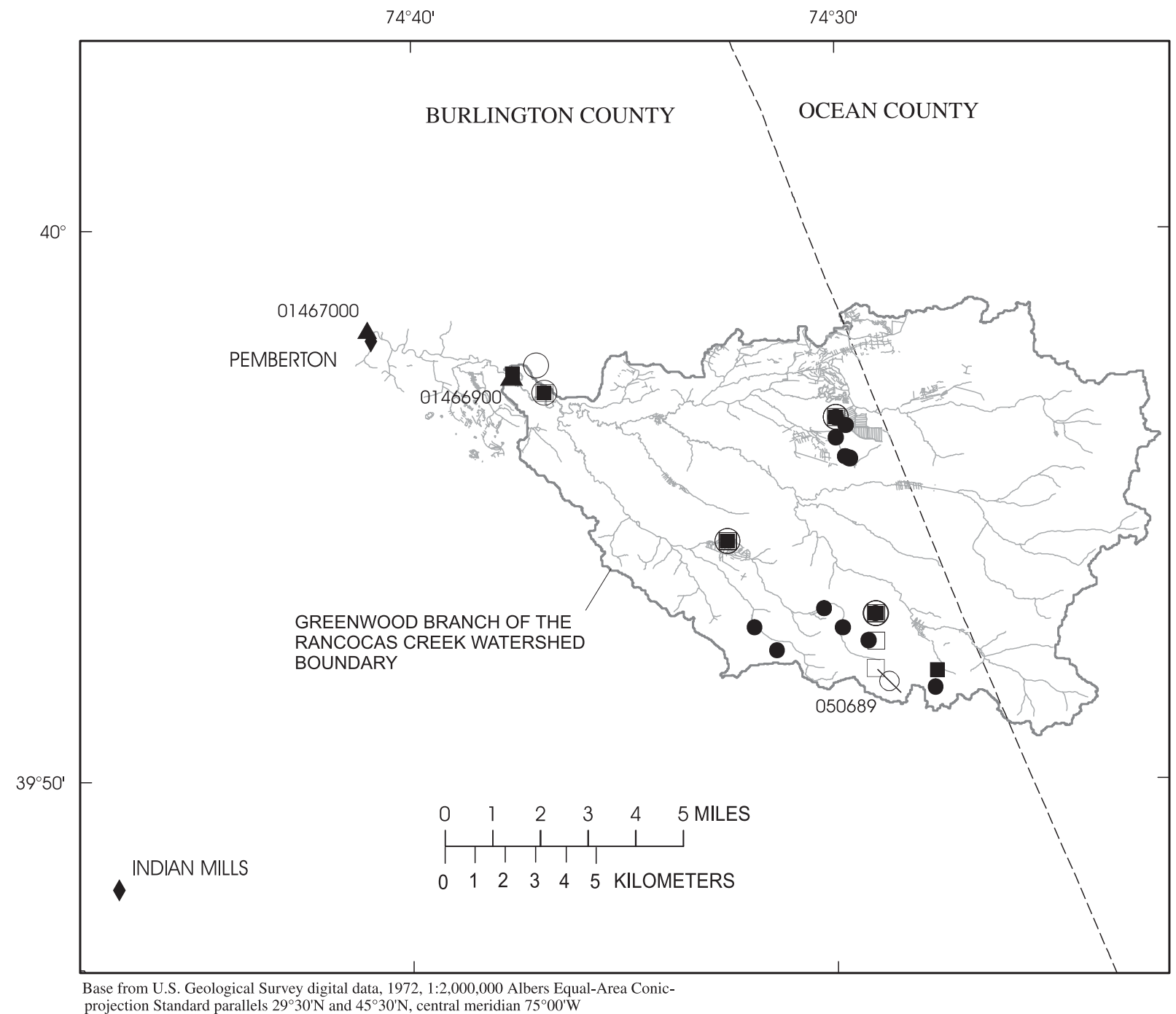

\section{EXPLANATION}

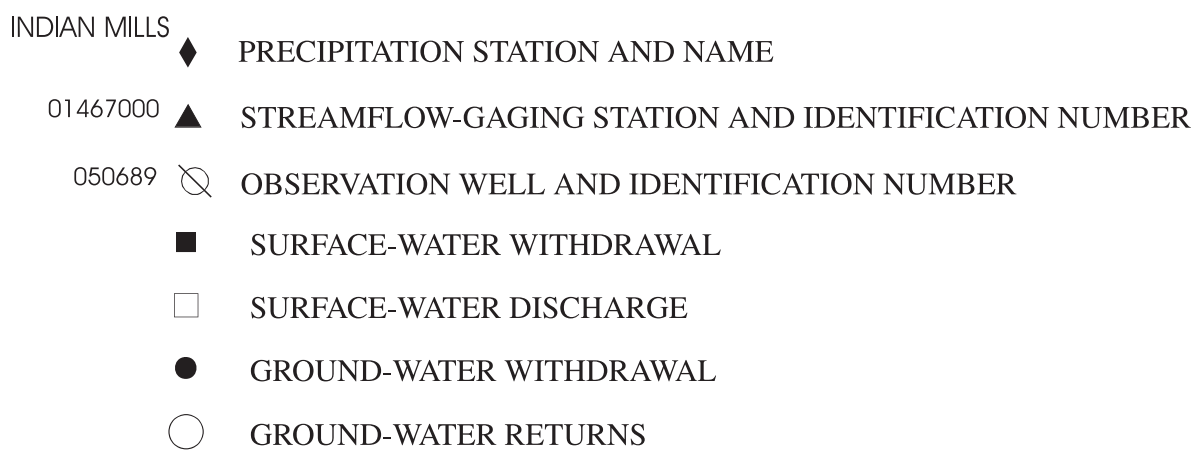

Figure 10. Greenwood Branch of the Rancocas Creek watershed, Burlington and Ocean Counties, New Jersey. Location of watershed shown on figure 1. 
The basin water-budget equation (eq. 5) was adjusted for conditions in the Greenwood Branch of Rancocas Creek watershed. This watershed does not have imported water, surface-water impoundments, or ground-water exports; therefore, those terms are not included in equation 14.

Water budgets for the Greenwood Branch of Rancocas Creek for 1988-2002 are presented in table 10. The ET term, which includes evapotranspiration plus all errors in measurement or estimation of the other water budget terms, ranged from $9.00 \mathrm{in}$. in 1998 to $32.73 \mathrm{in}$. in 2002 and averaged 23.43 in. for the 15-year period of study (table 10). ET for the entire Rancocas Creek watershed was estimated to be 25.9 in (Watt and others, 2003).

Digital precipitation data were available from two NOAA precipitation gages: Pemberton (1931-2002) and Indian Mills (1931-2002). The principal data set was from the Pemberton gage, and data from the Indian Mills gage were used to supplement that data set for months with missing data. Annual precipitation (P) ranged from 31.84 in. in 2001 to 59.16 in. in 1996 and averaged 44.73 in. (table 10).
Data from the USGS streamflow-gaging station North Branch Rancocas Creek at Pemberton, N.J., was used to calculate the streamflow component of the water budget. Streamflow (SF) ranged from 10.69 in. in 2002 to 27.30 in. in 1996 and averaged $18.25 \mathrm{in}$. (table 10).

Water-level data used to estimate the annual change in ground-water storage were available from Lebanon State Forest observation well 23D (identification number 050689) (fig. 10). The annual change in water level in observation well 050689 was multiplied by an estimated average specific yield of 0.2 to calculate the change in ground-water storage for the watershed. The estimated average specific yield was calculated from several New Jersey Coastal Plain studies. Rhodehamel (1973) estimated a specific yield of 0.16 for the Kirkwood-Cohansey aquifer system in the Mullica River Basin, Atlantic and Burlington Counties, N.J., from aquifer tests, and Rhodehamel (1970) suggested an estimated specific yield of 0.21 for the Cohansey Sand in the Pine Barrens region of New Jersey. Barksdale and others (1958) reported a weighted average specific yield of 0.23 for the Cohansey Sand in the southwestern part of the New

Table 10. Basin water budget for the Greenwood Branch of the Rancocas Creek watershed, Burlington and Ocean Counties, New Jersey, 1988-2002.

[All units are given in inches]

\begin{tabular}{|c|c|c|c|c|c|c|c|}
\hline Year & $\begin{array}{l}\text { Precipitation } \\
\text { (P) }\end{array}$ & $\begin{array}{c}\text { Streamflow } \\
\text { (SF) }\end{array}$ & $\begin{array}{c}\text { Change in } \\
\text { ground-water } \\
\text { storage } \\
\text { (UGWS) }\end{array}$ & $\begin{array}{l}\text { Ground- } \\
\text { water } \\
\text { leakage } \\
\text { (GWL) }\end{array}$ & $\begin{array}{c}\text { Surface-water } \\
\text { exports } \\
\text { (SWEXP) }\end{array}$ & $\begin{array}{l}\text { Consumptive use } \\
\text { (CON) }\end{array}$ & $\begin{array}{l}\text { Evapotranspiration } \\
\text { (ET) and errors }\end{array}$ \\
\hline 1988 & 37.90 & 14.16 & -5.40 & 2.87 & 0.38 & 0.14 & 25.75 \\
\hline 1989 & 54.22 & 23.51 & 14.81 & 2.88 & .39 & .14 & 12.49 \\
\hline 1991 & 48.21 & 18.15 & -2.30 & 2.87 & .35 & .12 & 29.02 \\
\hline 1992 & 43.57 & 16.21 & 4.34 & 2.88 & .25 & .12 & 19.76 \\
\hline 1993 & 50.38 & 21.34 & -1.22 & 2.87 & .16 & .14 & 27.09 \\
\hline 1994 & 49.12 & 21.96 & -3.24 & 2.87 & .35 & .12 & 27.06 \\
\hline 1998 & 36.34 & 21.14 & 3.02 & 2.88 & .14 & .16 & 9.00 \\
\hline${ }^{2} 1999$ & 45.87 & 17.48 & -2.42 & 2.88 & .21 & .16 & 27.56 \\
\hline 2000 & 42.68 & 16.51 & .34 & 2.88 & .32 & .16 & 22.47 \\
\hline${ }^{3} 2001$ & 31.84 & 14.41 & -1.99 & 2.88 & .41 & .16 & 15.97 \\
\hline 2002 & 46.68 & 10.69 & -.19 & 2.88 & .41 & .16 & 32.73 \\
\hline Average & 44.73 & 18.25 & -0.27 & 2.88 & 0.30 & 0.14 & 23.43 \\
\hline
\end{tabular}

\footnotetext{
${ }^{1}$ Wet year.
}

${ }^{2}$ Average year.

${ }^{3}$ Dry year. 
Jersey Coastal Plain from laboratory samples. The annual change in ground-water storage $(\Delta \mathrm{GWS})$ ranged from a loss of 7.90 in. in 1990 to a gain of 14.81 in. in 1989 and averaged -0.27 in. (table 10).

Data for ground-water leakage (GWL) from the unconfined aquifer to the confined aquifer were available from RASA model simulations for 1988-1998. Ground-water leakage for 1999-2002 was assumed to be the same as in 1998. The range for ground-water leakage was small, from 2.85 in. in 1990 to $2.89 \mathrm{in}$. in 1997; the average was 2.88 in. (table 10).

Surface-water exports (SWEXP) ranged from 0.14 in. in 1998 to 0.42 in. in 1990 and averaged 0.30 in. (table 10).

Surface-water exports fluctuated throughout the study period (fig. 11).

Consumptive water use $(\mathrm{CON})$ is estimated at 6 percent for cranberry production and 8 percent for sand mining (J.P. Nawyn, U.S. Geological Survey, oral commun., 2004). Consumptive use (CON) ranged from 0.11 in. in 1997 to 0.16 from 1998 to 2002 and averaged 0.14 in. (table 10).

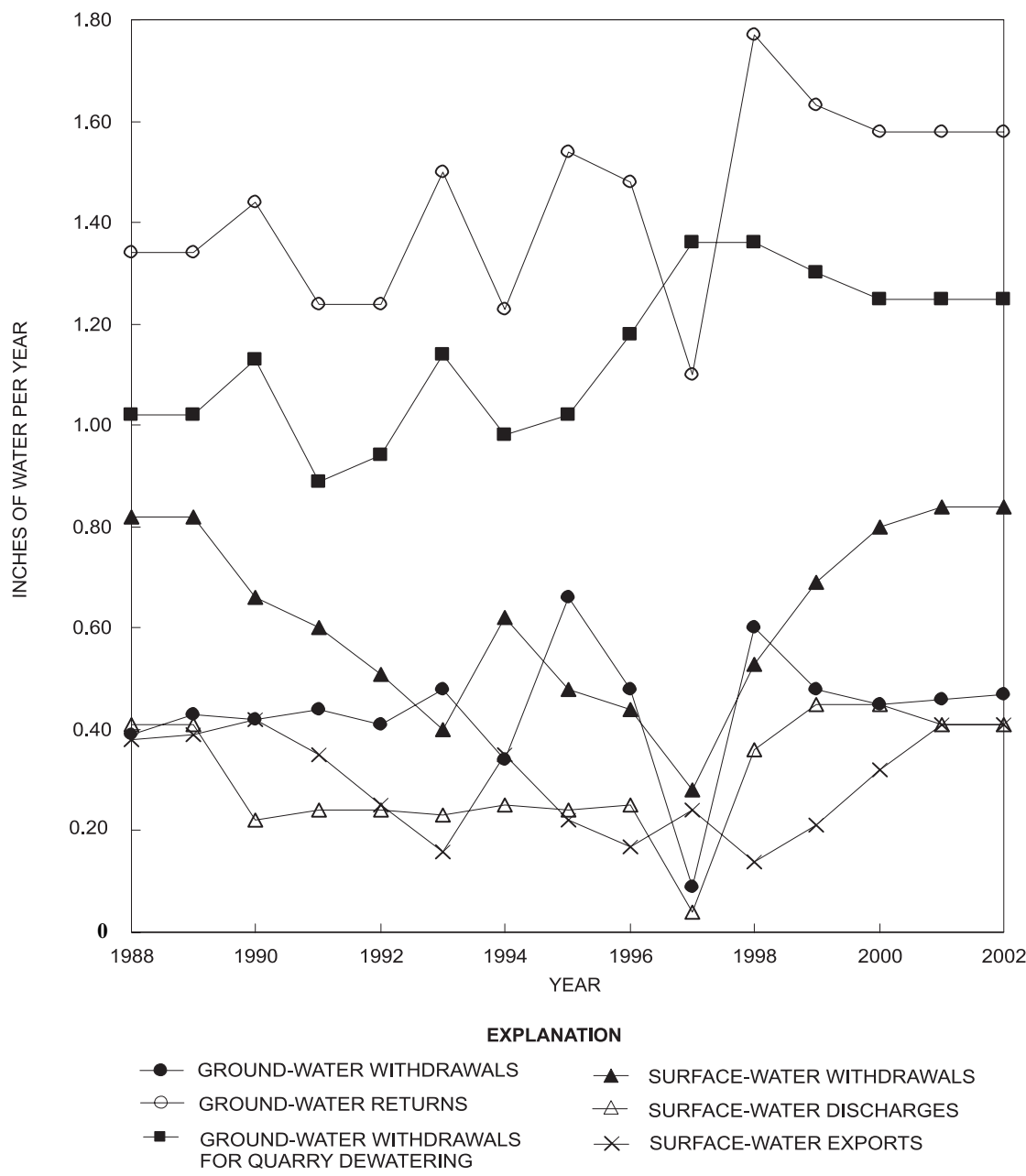

Figure 11. Surface-water and ground-water withdrawals and discharges and surface-water exports in the Greenwood Branch of the Rancocas Creek watershed, Burlington and Ocean Counties, New Jersey, 1988-2002.
The following equation was used to calculate the wateruse budget for the Greenwood Branch of Rancocas Creek watershed:

$$
\begin{aligned}
& \text { GWW + QGWW - GWR + SWW } \\
& \text { - SWEXP - SWD - CON = RES. }
\end{aligned}
$$

The water-use budget equation (eq. 7) was adjusted for conditions in the Greenwood Branch of Rancocas Creek watershed. This watershed does not have ground-water exports or imported water; therefore, those terms are not included in equation 15. Water-use budgets for the Greenwood Branch of Rancocas Creek watershed for 1988-2002 are presented in table 11.

Ground-water-withdrawal data for mining (QGWW) by the Clayton Sand Company were available for 1989-2000, and missing data were assumed to be the same as in the preceding or past years. Ground-water withdrawals (GWW) from the unconfined Kirkwood-Cohansey aquifer ranged from 0.09 in. in 1997 to 0.66 in. in 1995 and averaged 0.44 in. (table 11). In general, ground-water withdrawals from the unconfined system have been fairly stable, except from 1995 to 1998 (fig. 11). Ground-water withdrawals for mining (QGWW) ranged from 0.89 in. in 1991 to 1.36 in. in 1997-98 and averaged $1.14 \mathrm{in.}$ (table 11). Ground-water withdrawals for quarry dewatering generally have increased over time (fig. 11). Ground-water returns are recharge from water that was pumped for sand-mine dewatering and pumped but not used for cranberry production. Ground-water returns (GWR) ranged from 1.10 in. in 1997 to 1.77 in. in 1998 and averaged 1.42 in. (table 11). Ground-water returns fluctuated over time (fig. 11).

Surface water was withdrawn for cranberry production and by the Fort Dix Army Base north of the watershed for public supply. Surface-water withdrawals (SWW) ranged from 0.28 in. in 1997 to 0.84 in. in 2001-02 and averaged 0.62 in. (table 11). Surface-water withdrawals declined until 1997, then rose steadily (fig. 11). Surface-water discharge is water returned to the stream from water that was pumped but was not consumed. Surfacewater discharge (SWD) ranged from $0.04 \mathrm{in}$. in 1997 to 0.45 in. in 1999-2000 and averaged 0.31 in. (table 11). Surface-water discharges generally were stable from 1990 to 1996 and then fluctuated (fig. 11).

The residual (RES), which is the difference between sources and destinations of water, is less than or equal to $0.24 \mathrm{in}$. and averaged $0.03 \mathrm{in}$. for the period of study. The average residual for the 15-year period of study is about 1 percent of the sum of the averages of the sources $(\mathrm{GWW}+\mathrm{QGWW}+\mathrm{SWW})$. 
Years representing dry, average, and wet years determined by annual precipitation were chosen from the water budgets presented in table 10. 2001 represents a dry year with 31.84 in. of precipitation, which is $12.89 \mathrm{in}$. less than the 15 -year average. Streamflow was 14.41 in., which is 3.84 in. less than the 15-year average. The watershed lost 1.99 in. of ground water from storage, and in the two previous years, 1999-2000, there also was a net loss in storage. The loss in storage is reflected in the lower streamflow in 2002. Even though the precipitation in 2002 was 46.68 in., which is above the 15 -year average, the streamflow was 7.56 in. below the 15 -year average, reflecting the net loss in ground-water storage for 1999-2002. The estimated ET in 2001 was 15.97 in. and was 7.46 in. less than the 15 -year average.

1999 represents an average year with precipitation exceeding the 15 -year average by $1.14 \mathrm{in}$. Streamflow was $0.77 \mathrm{in}$. less than the 15-year average, and ET exceeded the 15-year average by 4.13 in.

1996 represents a wet year with 59.16 in. of precipitation, which is 14.43 in. above the 15 -year average. Streamflow in
1996 was the highest for the 15-year period and was 9.05 in. greater than the 15-year average. Ground-water storage increased by $9.65 \mathrm{in}$. The estimated ET was 19.02 in., which is $4.41 \mathrm{in}$. less than the 15-year average ET.

The hydrograph from streamflow-measurement station North Branch Rancocas Creek at Pemberton, N.J., was separated into base-flow and surface-runoff components by the local minimum method of the HYSEP computer program (Sloto and Crouse, 1996). The record at this station is not affected by substantial surface-water returns above the streamflow-gaging station. Most ground-water withdrawal minus consumptive use is returned to the system as ground-water recharge. Base flow ranged from $8.64 \mathrm{in}$. in 2002 to $19.87 \mathrm{in}$. in 1996 and averaged 13.83 in. (table 12). Base flow, on average, made up

75.8 percent of the streamflow for the 15 -year period of study.

The Greenwood Branch of the Rancocas Creek watershed is a rural watershed dominated by forest and wetlands. Many private residences relied on domestic wells and septic systems. Most of the water supply in this area came from confined aquifers, including half of the domestic wells (Watt and others,

Table 11. Water-use budget for the Greenwood Branch of the Rancocas Creek watershed, Burlington and Ocean Counties, New Jersey, 1988-2002.

[All units are given in inches]

\begin{tabular}{|c|c|c|c|c|c|c|c|c|}
\hline Year & $\begin{array}{l}\text { Ground-water } \\
\text { withdrawals } \\
\text { (GWW) }\end{array}$ & $\begin{array}{c}\text { Quarry } \\
\text { ground-water } \\
\text { withdrawals } \\
\text { (QGWW) }\end{array}$ & $\begin{array}{l}\text { Returns to } \\
\text { ground } \\
\text { water } \\
\text { (GWR) }\end{array}$ & $\begin{array}{c}\text { Surface- } \\
\text { water } \\
\text { withdrawals } \\
\text { (SWW) }\end{array}$ & $\begin{array}{c}\text { Surface- } \\
\text { water } \\
\text { exports } \\
\text { (SWEXP) }\end{array}$ & $\begin{array}{l}\text { Discharge to } \\
\text { surface water } \\
\text { (SWD) }\end{array}$ & $\begin{array}{l}\text { Consumptive use } \\
\text { (CON) }\end{array}$ & $\begin{array}{c}\text { Residual } \\
\text { (RES) }\end{array}$ \\
\hline 1988 & 0.39 & 1.02 & 1.34 & 0.82 & 0.38 & 0.41 & 0.14 & -0.04 \\
\hline 1989 & .43 & 1.02 & 1.34 & .82 & .39 & .41 & .14 & -.01 \\
\hline 1990 & .42 & 1.13 & 1.44 & .66 & .42 & .22 & .13 & .00 \\
\hline 1991 & .44 & .89 & 1.24 & .60 & .35 & .24 & .12 & -.02 \\
\hline 1992 & .41 & .94 & 1.24 & .51 & .25 & .24 & .12 & .01 \\
\hline 1993 & .48 & 1.14 & 1.50 & .40 & .16 & .23 & .14 & -.01 \\
\hline 1994 & .34 & .98 & 1.23 & .62 & .35 & .25 & .12 & -.01 \\
\hline 1995 & .66 & 1.02 & 1.54 & .48 & .22 & .24 & .14 & .02 \\
\hline${ }^{1} 1996$ & .48 & 1.18 & 1.48 & .44 & .17 & .25 & .14 & .06 \\
\hline 1997 & .09 & 1.36 & 1.10 & .28 & .24 & .04 & .11 & .24 \\
\hline 1998 & .60 & 1.36 & 1.77 & .53 & .14 & .36 & .16 & .06 \\
\hline${ }^{2} 1999$ & .48 & 1.30 & 1.63 & .69 & .21 & .45 & .16 & .02 \\
\hline 2000 & .45 & 1.25 & 1.58 & .80 & .32 & .45 & .16 & -.01 \\
\hline${ }^{3} 2001$ & .46 & 1.25 & 1.58 & .84 & .41 & .41 & .16 & -.01 \\
\hline 2002 & .47 & 1.25 & 1.58 & .84 & .41 & .41 & .16 & .00 \\
\hline Average & 0.44 & 1.14 & 1.42 & 0.62 & 0.30 & 0.31 & 0.14 & 0.03 \\
\hline
\end{tabular}

${ }^{1}$ Wet year.

${ }^{2}$ Average year.

${ }^{3}$ Dry year. 
2003). Most ground-water withdrawals were for public supply and quarry dewatering. Most surface-water withdrawals were for public and agricultural supply. The main type of agriculture was cranberry production. Surface water was exported for use at the Fort Dix Army Base, which is north of the watershed.

Most ground-water consumptive use was for cranberry production and sand mining, while most surface-water consumptive use was mainly for cranberry production. Ground-water returns were dominated by water used for cranberry production and quarry dewatering. Surface-water discharge was mainly from cranberry production.

\section{Cooper River Watershed}

The 51.3- $\mathrm{mi}^{2}$ Cooper River watershed in Camden and Burlington Counties, N.J., represents an urban Coastal Plain watershed (fig. 12). Most of the watershed is developed with few wells withdrawing water from unconfined aquifers. These wells are in the southeastern section of the watershed and are used for irrigation. The southeastern section of the watershed is rural and is served by domestic wells and septic systems. Water from many of the large-capacity public-supply wells and imported from sources outside the watershed comes from the confined aquifers of the middle and lower Magothy-Raritan-Potomac aquifer system of the Coastal Plain. The Camden County Municipal Utility Authority began a regional sewering project

Table 12. Base flow for the streamflow-gaging station Greenwood Branch of the Rancocas Creek at New Lisbon, New Jersey, 19882002.

[All quantities given in inches]

\begin{tabular}{lcccc}
\hline Year & Streamflow & $\begin{array}{c}\text { Surface } \\
\text { runoff }\end{array}$ & Base flow & $\begin{array}{c}\text { Percentage of } \\
\text { base flow }\end{array}$ \\
\hline 1988 & 14.16 & 2.60 & 11.56 & 81.6 \\
1989 & 23.51 & 5.95 & 17.56 & 74.7 \\
1990 & 21.35 & 5.24 & 16.11 & 75.5 \\
1991 & 18.15 & 4.48 & 13.66 & 75.3 \\
1992 & 16.21 & 4.86 & 11.34 & 70.0 \\
1993 & 21.34 & 4.49 & 16.85 & 79.0 \\
1994 & 21.96 & 5.29 & 16.67 & 75.9 \\
1995 & 11.12 & 2.23 & 8.89 & 80.0 \\
1996 & 27.30 & 7.43 & 19.87 & 72.8 \\
1997 & 18.38 & 3.72 & 14.66 & 79.8 \\
1998 & 21.14 & 6.51 & 14.63 & 69.2 \\
1999 & 17.48 & 4.84 & 12.64 & 72.3 \\
2000 & 16.51 & 3.54 & 12.97 & 78.6 \\
2001 & 14.41 & 3.02 & 11.39 & 79.0 \\
2002 & 10.69 & 2.05 & 8.64 & 80.8 \\
& & & & 75.8 \\
\hline Average & 18.25 & 4.42 & 13.83 &
\end{tabular}

in the mid-1980s. In 1987, two-thirds of the county was sewered, and by January 1991, all 37 municipalities were online. Thirty-two municipalities have sewer connections that drain to the Delaware River Basin, and five have sewer connections that drain to the Atlantic Basin.

Ground-water-withdrawal (1990-1999), surface-waterwithdrawal (1990-1999), ground-water-discharge (1999), and surface-water-discharge (1990-91) data were provided by the DRBC. These data were supplemented for 1988-2002 with data from the Camden County Municipal Utility Authority, New Jersey Department of Environmental Protection Bureau of Water Allocation, USGS SWUDS, and USGS GWSI.

The following equation was used to calculate the basin water budget for the Cooper River watershed:

$$
\mathrm{P}=\mathrm{SF} \Delta \mathrm{GWS} \mathrm{GWL}+\mathrm{GWEXP}+\mathrm{CON}+\mathrm{ET} .
$$

The basin water-budget equation (eq. 5) was adjusted for conditions in the Cooper River watershed. This watershed does not have imported water, exported surface water, or surface-water impoundments; therefore, those terms are not included in equation 16.

Annual basin water budgets for the Cooper River watershed for 1988-2002 are presented in table 13. The ET term, which includes evapotranspiration plus all errors in measurement or estimation of the other water-budget terms, ranged from 15.07 in. in 1989 to 33.20 in. in 2002 and averaged 24.13 in. (table 13).

Digital precipitation data were available from two NOAA precipitation gages: Moorestown (1931-2003) and Audubon (1950-1990). Data from the Moorestown gage northeast of the watershed were used for the water budgets, and data from the Audubon gage were used for comparison for January 1988 to March 1990. Annual precipitation (P) ranged from 37.32 in. in 1998 to 62.05 in. in 1996 and averaged 47.11 in. (table 13).

Data from USGS streamflow-gaging station Cooper River at Haddonfield, N.J. (station number 01467150), was used to calculate the streamflow component of the water budget. Streamflow (SF) ranged from $16.79 \mathrm{in.}$ in 2002 to $32.91 \mathrm{in.}$ in 1996 and averaged 22.13 in. (table 13).

Water-level data used to estimate the annual change in ground-water storage were available from the Winslow 5 observation well (identification number 070503) (fig. 12). This well is approximately $5 \mathrm{mi}$ south of the watershed and was used because there are no observation wells within the watershed. The annual change in water level in observation well 070503 was multiplied by an estimated average specific yield of 0.2 , the same value used for the Greenwood Branch watershed, to calculate the change in ground-water storage for the watershed. The annual change in ground-water storage ( $\Delta \mathrm{GWS}$ ) ranged from a loss of 4.82 in. in 1990 to a gain of 11.47 in. in 1989 and averaged 0.11 in. (table 13 ).

Ground-water leakage (GWL) from the unconfined aquifer to the confined aquifer was available from RASA model simulations for 1988-1998. Ground-water leakage for 19992002 was assumed to be the same as in 1998. Ground-water 


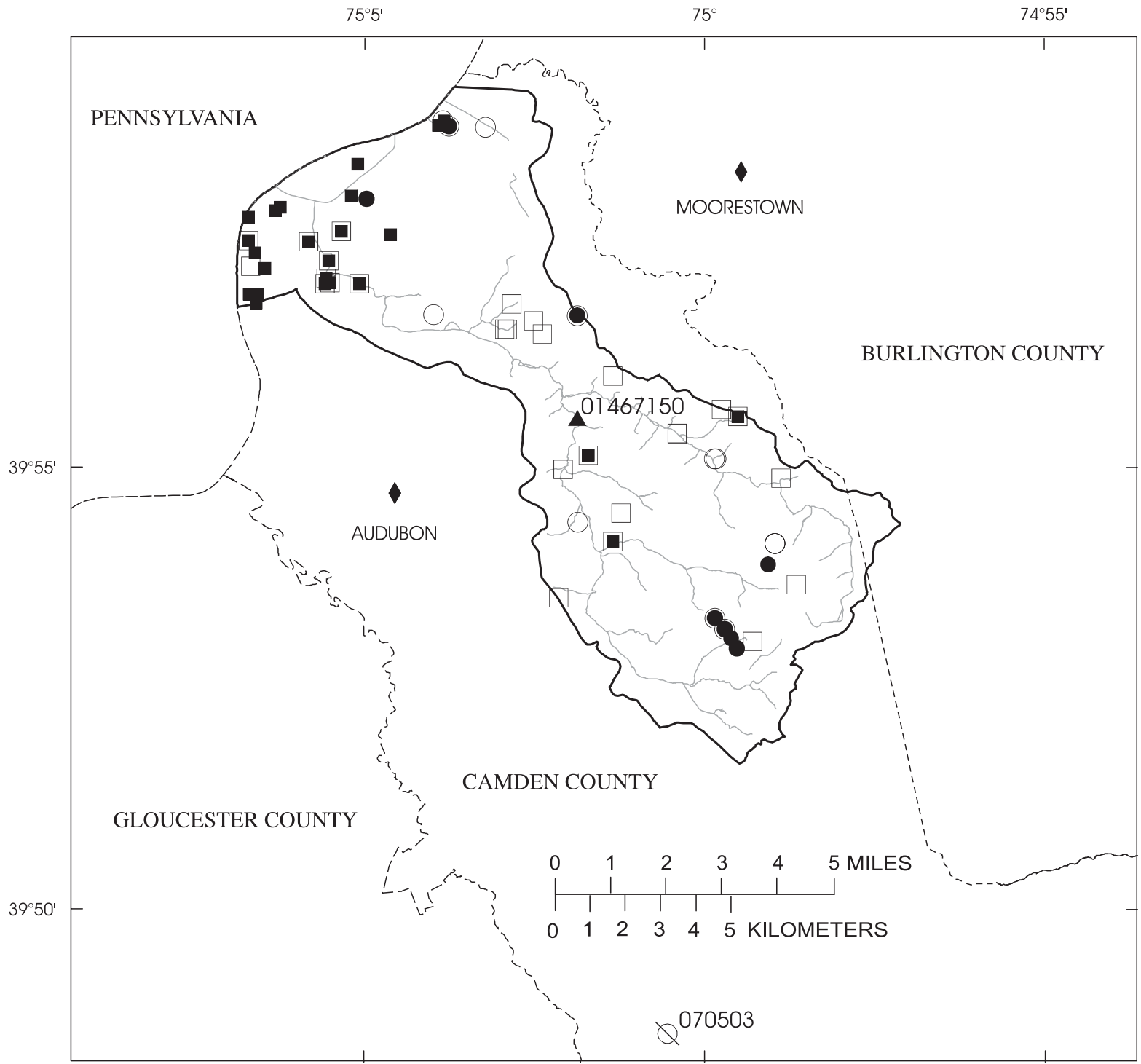

Base from U.S. Geological Survey digital data, 1972, 1:2,000,000 Albers Equal-Area Conicprojection Standard parallels $29^{\circ} 30^{\prime} \mathrm{N}$ and $45^{\circ} 30^{\prime} \mathrm{N}$, central meridian $75^{\circ} 00^{\prime} \mathrm{W}$

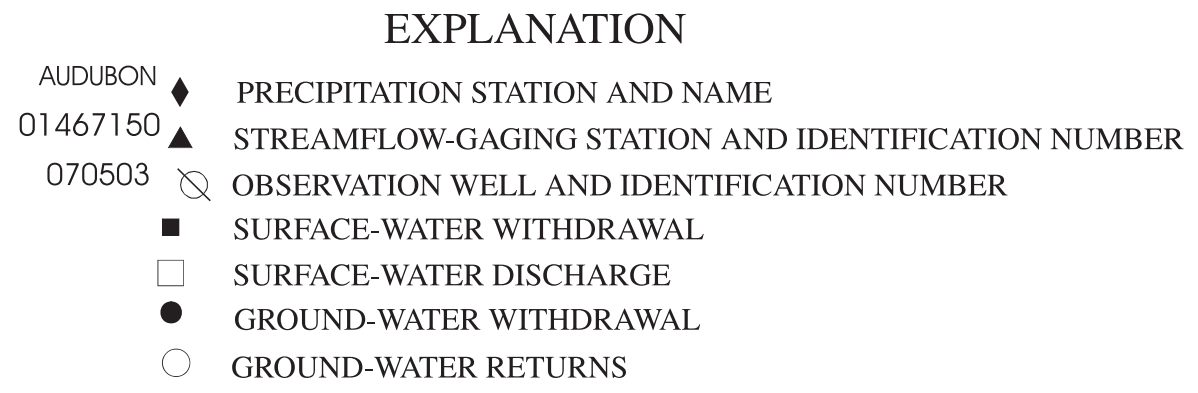

Figure 12. Cooper River watershed, Camden and Burlington Counties, New Jersey. Location of watershed shown on figure 1. 
leakage ranged from 0.28 in. in 1988 to 1.06 in. in 1997 and averaged 0.62 in. (table 13). Leakage to confined aquifers increased over the 15-year period (fig. 13).

Ground-water exports for the unconfined system for the period 1988-2002 for the basin were estimated from the percentage total ground-water exports that were from the unconfined aquifer (table 13). Ground-water exports (GWEXP) ranged from 0.002 in. 1988 to 0.021 in. in 2002 and averaged 0.009 in. (table 13).

Consumptive water use is estimated at 90 percent for golfcourse, agricultural, and nonagricultural irrigation (J. Hoffman, New Jersey Geological Survey, written commun., 2004). Consumptive use (CON) ranged from $0.02 \mathrm{in}$. in 1994 to $0.24 \mathrm{in}$. in 1989 and averaged $0.10 \mathrm{in}$. (table 13).

The following equation was used to calculate the wateruse budget for the Cooper River watershed:

GWW + SWW - GWEXP - GWR - SWD - CON = RES. (17)

The water-use budget equation (eq. 7) was adjusted for conditions in the Cooper River watershed. This watershed does not have ground-water pumpage for quarry operations, imported water, or surface-water exports; therefore, those terms are not included in equation 17. Water-use budgets for the Cooper River watershed for 1988-2002 are presented in table 14.

Ground water was withdrawn from unconfined aquifers for golf-course, agricultural, and nonagricultural irrigation. Data for a small group of wells was available to calculate ground-water withdrawals (GWW) from unconfined aquifers. Pumpage was steady for most of the 15 -year period at 0.02 in. with an increase to 0.03 in. in 2002 (table 14). Ground-water returns were recharge to the ground-water system from water that was pumped for golf-course, agricultural, and nonagricultural irrigation, but was not consumed. Ground-water returns (GWR) were less than $0.01 \mathrm{in}$. (table 14).

Surface water was withdrawn for golf-course irrigation, agricultural use, and some industrial use. Surface-water withdrawals (SWW) ranged from 0.15 in. in 1998 to 2.43 in. in 1989 and averaged 0.77 in. (table 14). Surface-water withdrawals declined during the 15-year period (fig. 13). Surface-waterdischarge data were available for most sites for 1988-2001. Discharge to surface water declined after 1990 as regional sewering took over from 1987 to the early 1990s (fig. 13). Surface-

Table 13. Basin water budget for the Cooper River watershed, Camden and Burlington Counties, New Jersey, $1988-2002$.

[All units are given in inches.]

\begin{tabular}{|c|c|c|c|c|c|c|c|}
\hline Year & $\begin{array}{l}\text { Precipitation } \\
\text { (P) }\end{array}$ & $\begin{array}{c}\text { Streamflow } \\
\text { (SF) }\end{array}$ & $\begin{array}{c}\text { Change in } \\
\text { ground-water } \\
\text { storage } \\
(\Delta \text { GWS })\end{array}$ & $\begin{array}{l}\text { Ground- water } \\
\text { leakage } \\
\text { (GWL) }\end{array}$ & $\begin{array}{l}\text { Ground- } \\
\text { water } \\
\text { exports } \\
\text { (GWEXP) }\end{array}$ & $\begin{array}{c}\text { Consumptive } \\
\text { use } \\
\text { (CON) }\end{array}$ & $\begin{array}{c}\text { Evapotranspiration } \\
\text { (ET) } \\
\text { and errors }\end{array}$ \\
\hline 1988 & 45.70 & 20.46 & -4.18 & 0.28 & 0.002 & 0.16 & 28.97 \\
\hline 1989 & 57.06 & 29.94 & 11.47 & .33 & .003 & .24 & 15.07 \\
\hline 1990 & 44.14 & 21.97 & -4.82 & .64 & .006 & .22 & 26.12 \\
\hline${ }^{1} 1991$ & 47.24 & 21.18 & -1.25 & .48 & .007 & .21 & 26.61 \\
\hline 1992 & 44.41 & 18.70 & .98 & .45 & .007 & .13 & 24.14 \\
\hline 1993 & 50.93 & 24.94 & 2.81 & .60 & .007 & .05 & 22.52 \\
\hline 1994 & 53.19 & 30.02 & 1.30 & .44 & .009 & .02 & 21.40 \\
\hline 1995 & 38.09 & 17.15 & -2.35 & .45 & .009 & .04 & 22.79 \\
\hline${ }^{2} 1996$ & 62.05 & 32.91 & 5.71 & .50 & .009 & .03 & 22.89 \\
\hline 1997 & 39.24 & 19.39 & -2.54 & 1.06 & .013 & .03 & 21.28 \\
\hline${ }^{3} 1998$ & 37.32 & 18.29 & -4.20 & .81 & .015 & .06 & 22.34 \\
\hline 1999 & 52.53 & 20.75 & -.07 & .81 & .012 & .10 & 30.92 \\
\hline 2000 & 48.03 & 21.73 & 3.60 & .81 & .013 & .08 & 21.79 \\
\hline 2001 & 37.88 & 17.77 & -2.66 & .81 & .012 & .10 & 21.84 \\
\hline 2002 & 48.80 & 16.79 & -2.11 & .81 & .021 & .08 & 33.20 \\
\hline Average & 47.11 & 22.13 & 0.11 & 0.62 & 0.009 & 0.10 & 24.13 \\
\hline
\end{tabular}


Table 14. Water-use budget for the Cooper River watershed, Camden and Burlington Counties, New Jersey, 19882002.

[All units are given in inches]

\begin{tabular}{|c|c|c|c|c|c|c|c|}
\hline Year & $\begin{array}{c}\text { Ground- } \\
\text { water } \\
\text { withdrawals } \\
\text { (GWW) }\end{array}$ & $\begin{array}{l}\text { Ground- } \\
\text { water } \\
\text { exports } \\
\text { (GWEXP) }\end{array}$ & $\begin{array}{l}\text { Returns to } \\
\text { ground water } \\
\text { (GWR) }\end{array}$ & $\begin{array}{c}\text { Surface- } \\
\text { water } \\
\text { withdrawals } \\
\text { (SWW) }\end{array}$ & $\begin{array}{l}\text { Discharge to } \\
\text { surface water } \\
\text { (SWD) }\end{array}$ & $\begin{array}{l}\text { Consumptive use } \\
\text { (CON) }\end{array}$ & $\begin{array}{l}\text { Residual } \\
\text { (RES) }\end{array}$ \\
\hline 1988 & 0.02 & 0.002 & 0.002 & 1.51 & 2.95 & 0.16 & -1.59 \\
\hline 1989 & .02 & .003 & .002 & 2.43 & 2.95 & .24 & -.75 \\
\hline 1990 & .02 & .006 & .001 & 2.10 & 2.95 & .22 & -1.06 \\
\hline${ }^{1} 1991$ & .02 & .007 & .002 & 1.82 & 1.56 & .21 & .06 \\
\hline 1992 & .02 & .007 & .002 & 1.24 & 1.11 & .13 & .01 \\
\hline 1993 & .02 & .007 & .002 & .63 & .39 & .05 & .20 \\
\hline 1994 & .02 & .009 & .002 & .18 & .01 & .02 & .15 \\
\hline 1995 & .02 & .009 & .002 & .20 & .01 & .04 & .15 \\
\hline${ }^{2} 1996$ & .02 & .009 & .002 & .19 & .03 & .03 & .14 \\
\hline 1997 & .02 & .013 & .002 & .22 & .07 & .03 & .12 \\
\hline${ }^{3} 1998$ & .02 & .015 & .002 & .15 & .01 & .06 & .08 \\
\hline 1999 & .02 & .012 & .002 & .24 & .07 & .10 & .07 \\
\hline 2000 & .02 & .013 & .002 & .19 & .07 & .08 & .04 \\
\hline 2001 & .02 & .012 & .002 & .21 & .07 & .10 & .04 \\
\hline 2002 & .03 & .021 & .003 & .18 & .07 & .08 & .03 \\
\hline Average & 0.02 & 0.009 & 0.002 & 0.77 & 0.82 & 0.10 & -0.15 \\
\hline
\end{tabular}

${ }^{1}$ Average year.

${ }^{2}$ Wet year.

${ }^{3}$ Dry year.

water discharge (SWD) ranged from 0.01 in. in 1994-1995 and 1998 to 2.95 in. in 1988-1990 and averaged 0.82 in. (table 14).

The residual (RES), which is the difference between sources and destinations of water, was much higher for 1988-90 than for other years (table 14). During this time discharge to surface water in the basin was high, and a regional sewer system was being constructed in the basin. The sewer system was running at full capacity by 1991 . This change is reflected in the residual, which averaged -0.15 in. for the 15 -year period of study.

Years representing dry, average, and wet years determined by annual precipitation were chosen from the water budgets presented in table 13. 1998 represents a dry year with 37.32 in. of precipitation, which is $9.79 \mathrm{in}$. less than the 15 -year average. Streamflow was 18.29 in., which is 3.84 in. less than the 15 -year average. The watershed lost $4.20 \mathrm{in}$. of water from storage. The estimated ET was 22.34 in., which is 1.79 in. less than the 15 -year average.

1991 represents an average year with precipitation exceeding the 15 -year average by only $0.13 \mathrm{in}$. Streamflow was

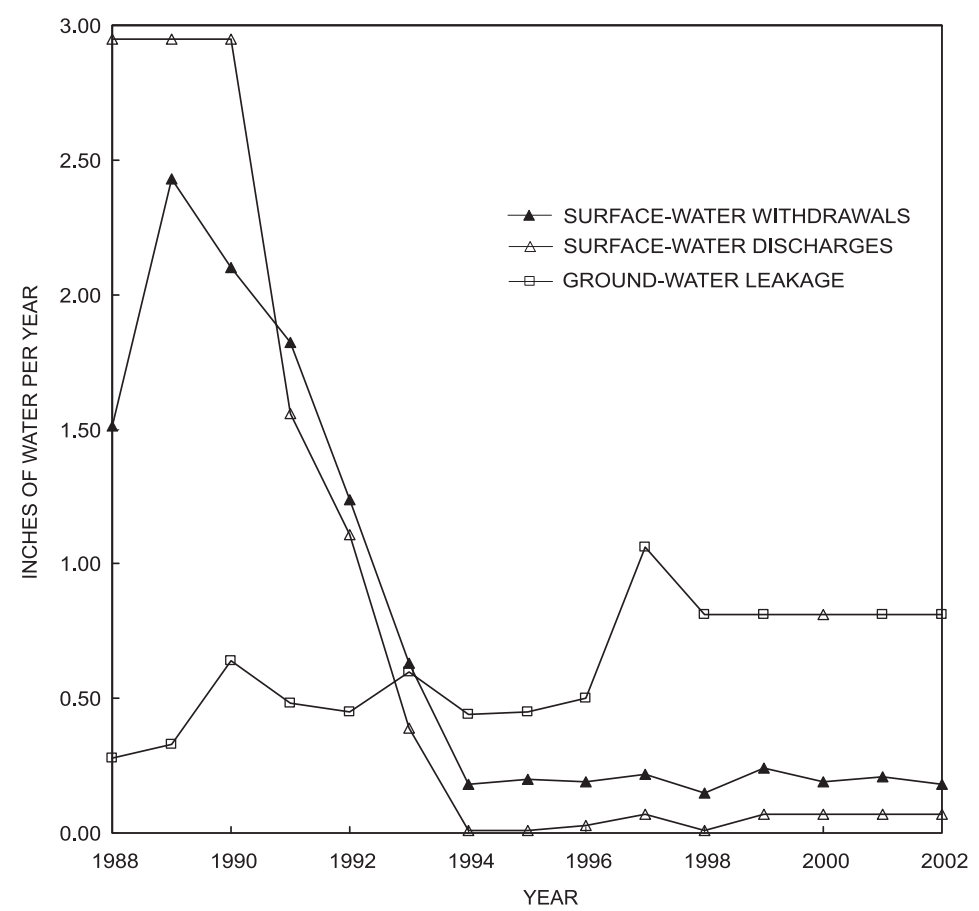

Figure 13. Surface-water withdrawals and discharges and ground-water leakage in the Cooper River watershed, Camden and Burlington Counties, New Jersey, 1988-2002. 
0.95 in. less than the 15-year average, and the ET exceeded the 15 -year average by 2.48 in.

1996 represents a wet year with 62.05 in. of precipitation, which is $14.94 \mathrm{in}$. above the 15 -year average. Streamflow in 1996 was the highest for the 15 -year period and was 10.78 in. greater than the 15-year average. Ground-water storage increased by $5.71 \mathrm{in}$. The estimated ET was $22.89 \mathrm{in}$., which is 1.24 in. less than the 15-year average.

The hydrograph from streamflow-gaging station Cooper River at Haddonfield, N.J., was separated into base-flow and surface-runoff components by the local minimum method of the HYSEP computer program (Sloto and Crouse, 1996). Groundwater and surface-water withdrawal and discharge above the station are small and do not affect base flow. Base flow ranged from 7.62 in. in 2002 to 14.75 in. in 1989 and averaged 11.10 in. (table 15). Base flow at the Cooper River at the Haddonfield station, on average, represents 50.2 percent of the streamflow for the 15-year period of study (table 15).

The Cooper River watershed is mostly urban with an intricate system of water use. The southeastern part of the watershed is rural and is mainly self-supplied. Most of the water exported from the basin came from confined aquifers. The small amount of water withdrawn from unconfined aquifers and surface-water sources was used for golf-course, agricultural, and nonagricultural irrigation and some industrial use. A regional sewer system completed in 1991 dramatically reduced discharge to surface water in the watershed. Ground-water consumptive use was mainly by golf-course, agricultural, and nonagricultural irrigation. Surface-water consumptive use was by golf course and general agricultural irrigation.

\section{Comparison of Water Budgets}

Water budgets for the five selected watersheds share a common period of record, 1988-98. Annual average values (11-year average) for selected water-budget components for the common period of record for the five watersheds are compared in table 16 to examine similarities and differences among the watersheds. Average annual precipitation ranged from 45.81 in. for the Greenwood Branch of the Rancocas Creek watershed to 50.52 in. for the Pocono Creek watershed. In general, precipitation is greatest in northeastern Pennsylvania and least in southern New Jersey. The precipitation distribution is in agreement with the annual precipitation distribution shown on the map of Jenner and Lins (1991, p. 59).

Average annual streamflow ranged from 19.51 in. for the Greenwood Branch of the Rancocas Creek watershed to 23.18 in. for the Cooper River watershed (table 16). For the Coastal Plain watersheds, downward leakage of ground water from the unconfined to the confined aquifers was 0.55 and 2.87 in. for the Cooper River and Greenwood Branch of the Rancocas Creek watersheds, respectively. The average annual change in ground-water storage ranged from a loss of $0.19 \mathrm{in.}$ for the East Branch Brandywine and Pocono Creek watersheds to a gain of 0.27 in. for the Cooper River watershed (table 16). The three fractured-rock watersheds lost water, and the two Coastal Plain watersheds gained water. Average annual consumptive use ranged from 0.06 in. in the Pocono Creek watershed to 1.98 in. in the Wissahickon Creek watershed. Average annual ET, which also includes errors in the measurement or estimation of the other water-budget components, ranged from 23.01 in. for the Greenwood Branch of the Rancocas Creek watershed to 28.68 in. for the Pocono Creek watershed (table 16). The higher value for the Pocono Creek watershed probably results from estimation of the streamflow record. Average annual ET values for the two Coastal Plain watersheds were similar.

Water was imported into two watersheds, surface water was exported from one watershed, and ground water was exported from four watersheds. Water was imported into the East Branch Brandywine (average 0.81 in.) and Wissahickon Creek (average 1.65 in.) watersheds. Average annual groundwater and surface-water exports were $0.30 \mathrm{in}$. or less for all watersheds except the Wissahickon Creek watershed, where the average annual ground-water export was 1.76 in. (table 16). Average annual ground-water exports exceeded water imports for the Wissahickon Creek watershed.

Ground-water withdrawals, not including quarry dewatering, ranged from 0.02 in. for the Cooper River watershed to 3.02 in. for the Wissahickon Creek watershed (table 16).

Table 15. Base flow for the streamflow-gaging station Cooper River at Haddonfield, New Jersey, 1988-2002.

[All units are given in inches]

\begin{tabular}{rrrrc}
\hline Year & Streamflow & $\begin{array}{c}\text { Surface } \\
\text { runoff }\end{array}$ & Base flow & $\begin{array}{c}\text { Percentage of base } \\
\text { flow as streamflow }\end{array}$ \\
\hline 1988 & 20.46 & 9.34 & 11.12 & 54.4 \\
1989 & 29.94 & 15.19 & 14.75 & 49.3 \\
1990 & 21.97 & 9.78 & 12.19 & 55.5 \\
1991 & 21.18 & 10.91 & 10.27 & 48.5 \\
1992 & 18.70 & 9.69 & 9.01 & 48.2 \\
1993 & 24.94 & 12.80 & 12.14 & 48.7 \\
1994 & 30.02 & 16.02 & 14.00 & 46.6 \\
1995 & 17.15 & 7.79 & 9.36 & 54.6 \\
1996 & 32.91 & 18.31 & 14.60 & 44.4 \\
1997 & 19.39 & 7.68 & 11.71 & 60.4 \\
1998 & 18.29 & 7.56 & 10.73 & 58.7 \\
1999 & 20.75 & 11.30 & 9.45 & 45.5 \\
2000 & 21.73 & 11.29 & 10.44 & 48.0 \\
2001 & 17.77 & 8.63 & 9.14 & 51.4 \\
2002 & 16.79 & 9.17 & 7.62 & 45.4 \\
& & & & 50.2 \\
\hline 1090 & 22.13 & 11.03 & 11.10 & \\
\hline
\end{tabular}


Table 16. Comparison of selected average values for water-budget components for the five watersheds for the common period of record 1988-98.

[Values are average values given in inches; --, not applicable; <. less than]

\begin{tabular}{|c|c|c|c|c|c|}
\hline Water-budget component & $\begin{array}{c}\text { East Branch } \\
\text { Brandywine } \\
\text { Creek watershed }\end{array}$ & $\begin{array}{l}\text { Wissahickon } \\
\text { Creek watershed }\end{array}$ & $\begin{array}{l}\text { Pocono Creek } \\
\text { watershed }\end{array}$ & $\begin{array}{l}\text { Greenwood Branch } \\
\text { of the Rancocas } \\
\text { Creek watershed }\end{array}$ & $\begin{array}{c}\text { Cooper River } \\
\text { watershed }\end{array}$ \\
\hline Precipitation $(\mathrm{P})$ & 47.19 & 47.88 & 50.52 & 45.81 & 47.22 \\
\hline Imported water (IMP) & .81 & 1.65 & -- & -- & -- \\
\hline Streamflow (SF) & 21.72 & 22.35 & 21.68 & 19.51 & 23.18 \\
\hline Ground-water leakage (GWL) & -- & -- & -- & 2.87 & .55 \\
\hline $\begin{array}{l}\text { Change in ground-water storage } \\
\text { ( } \Delta \text { GWS) }\end{array}$ & -.19 & -.10 & -.19 & .01 & .27 \\
\hline Consumptive use (CON) & .27 & 1.98 & .06 & .13 & .11 \\
\hline Evapotranspiration (ET) & 26.21 & 23.53 & 28.68 & 23.01 & 23.10 \\
\hline Ground-water withdrawals (GWW) & .27 & 3.02 & .78 & .43 & .02 \\
\hline Ground-water exports (GWEXP) & $<.01$ & 1.76 & .30 & -- & .01 \\
\hline Ground-water returns (GWR) & .10 & .01 & .34 & 1.38 & .00 \\
\hline $\begin{array}{l}\text { Quarry ground-water withdrawals } \\
\text { (QGWW) }\end{array}$ & -- & 2.93 & -- & 1.09 & -- \\
\hline $\begin{array}{l}\text { Percent of streamflow as base flow } \\
\text { (unadjusted) }\end{array}$ & 65.8 & 55.3 & -- & 75.8 & 51.8 \\
\hline $\begin{array}{l}\text { Percent of streamflow as base flow } \\
\text { (adjusted) }\end{array}$ & 60.9 & 30.1 & -- & -- & -- \\
\hline Surface-water withdrawals (SWW) & .62 & .09 & .08 & .56 & .97 \\
\hline Surface-water exports (SWEXP) & -- & -- & -- & .28 & -- \\
\hline Discharge to surface water (SWD) & 1.35 & 5.34 & .06 & .26 & 1.09 \\
\hline
\end{tabular}

Ground water was withdrawn for quarry dewatering only in the Wissahickon Creek and Greenwood Branch of the Rancocas Creek watersheds. The average annual ground-water withdrawal for quarry dewatering was $2.93 \mathrm{in}$. in the Wissahickon Creek watershed, which was equal to 49 percent of the total watershed ground-water withdrawal, and 1.09 in. in the Greenwood Branch of the Rancocas Creek watershed, which was equal to 72 percent of the total watershed ground-water withdrawal. Average annual returns to the ground-water system were 0.10 in. or less except in the Pocono Creek and Greenwood Branch of the Rancocas Creek watershed, where the average annual return was 0.34 and 1.38 in., respectively.

Average annual surface-water withdrawals ranged from 0.08 in. for the Pocono Creek watershed to 0.97 in. for the Cooper River watershed (table 16). The average annual discharge to surface water ranged from $0.06 \mathrm{in}$. for the Pocono Creek watershed to 5.34 in. for the Wissahickon Creek watershed. Surface-water discharge in the Wissahickon Creek watershed included discharge of water from quarry dewatering, several municipal sewage-treatment plants, and industries.
Base flow as a percentage of streamflow was higher for the rural watersheds than for the urban watersheds. On average, base flow as a percentage of streamflow ranged from 30.1 percent (adjusted) for the Wissahickon Creek watershed to 75.8 percent (unadjusted) for the Greenwood Branch of the Rancocas Creek watershed.

\section{Summary and Conclusions}

This study, done by the U.S. Geological Survey in cooperation with the Delaware River Basin Commission, was a pilot study to examine the feasibility of using available data to develop annual water budgets and water-use budgets. Five watersheds in the Delaware River Basin with different degrees of urbanization and different geological settings were selected for this study. Selected watersheds underlain by fractured rocks include the East Branch Brandywine Creek below Downingtown, Pocono Creek, and Wissahickon Creek in Pennsylvania. 
East Branch Brandywine Creek represents a watershed in transition from rural to suburban, with reservoir storage; Pocono Creek represents a rural watershed; and Wissahickon Creek represents an urban watershed. Selected watersheds underlain by Coastal Plain sediments include the Greenwood Branch of the Rancocas Creek and Cooper River in New Jersey. The Greenwood Branch of the Rancocas Creek represents a rural watershed, and the Cooper River represents an urban watershed. The span of years covered by the annual water budgets for each of the five watersheds differs because of differences in the availability of reliable water-use data.

Two water-budget equations were developed for each watershed, a basin water-budget equation and a water-use budget equation. The basin water-budget equation describes water inputs to the watershed (precipitation and imported water), outputs of water from the watershed [streamflow, exported water, leakage, consumed water, and evapotranspiration (ET)], and changes in ground-water and surface-water storage. The water-use budget equation describes water withdrawals in the watershed (ground-water and surface-water withdrawals), discharges of water in the watershed (discharge to surface water and ground water), and movement of water into and out of the watershed (imports, exports, and consumed water). Data used to develop the water budgets were obtained from available long-term meteorological and hydrological datacollection stations and from water-use data collected by regulatory agencies. Streamflow data were not available for the Pocono Creek watershed for the period covered by the water budgets, and, therefore, streamflow was estimated on the basis of the record from a nearby station. In the Coastal Plain watersheds, net ground-water loss from unconfined to confined aquifers was determined using ground-water-flow-model simulations.

The basin water-budget equation is solved for ET, the value of which is affected by errors in the measurement or estimation of the other water-budget terms. The terms in the wateruse budget are set equal to a residual, the magnitude of which is equal to the error in the water-budget terms caused by missing data, poor or incomplete measurements, and overestimated or underestimated quantities. Some of the error in the water-budget terms results from measurement or reporting errors, and some results from using point measurements, such as precipitation and water levels, to estimate an areal quantity, particularly if the watershed is hydrologically or geologically complex or the data-collection station is outside the watershed. The size of the watershed influences the magnitude of the water-budget components that are point measurements, such as withdrawals, discharges, imports, exports, and consumptive use. In contrast, the magnitudes of water-budget components that are areally distributed over the watershed, such as precipitation, streamflow, storage, and ET, are not affected by watershed size.

The complexity of the water budgets increases with increasing watershed urbanization and interbasin transfer of water. In the Wissahickon Creek watershed, for example, some ground water was discharged to streams in the watershed, some was exported as wastewater, and some was exported for public supply. In addition, ground water withdrawn outside the watershed was imported for public supply or imported as wastewater for treatment and discharge in the watershed. A GIS analysis was necessary to quantify many of the water-budget components.

The water-budget equations developed for this study can be applied to any watershed in the Delaware River Basin. The span of years covered by annual water budgets for other watersheds will depend on the availability of streamflow data and reliable water-use data.

The 89.9-square mile $\left(\mathrm{mi}^{2}\right)$ East Branch Brandywine Creek watershed in Pennsylvania is a rural watershed with reservoir storage that is underlain by fractured rock. Water budgets were developed for 1977-2001. Average annual precipitation, streamflow, and ET were 46.89, 21.58, and 25.88 in., respectively. Some water was imported (average of 0.68 in.) into the watershed for public-water supply and as wastewater for treatment and discharge; these imports resulted in a net gain of water to the watershed. More water was discharged to East Branch Brandywine Creek than was withdrawn from it; the net discharge resulted in an increase in streamflow. Most ground water was withdrawn (average of $0.25 \mathrm{in}$.) for public-water supply. Surface water was withdrawn (average of 0.58 in.) for publicwater and industrial supply. Discharge of water by sewagetreatment plants and industries (average of $1.22 \mathrm{in}$.) and regulation by Marsh Creek Reservoir caused base flow to appear an average of 7.2 percent higher than it would have been without these additional sources. On average, 67 percent of the difference was caused by sewage-treatment-plant and industrial discharges, and 33 percent was caused by regulation by the Marsh Creek Reservoir. Water imports, withdrawals, and discharges have been increasing over time as the watershed becomes more urbanized.

The 64-square mile Wissahickon Creek watershed in Pennsylvania is an urban watershed underlain by fractured rock. Water budgets were developed for 1987-98. Average annual precipitation, streamflow, and ET were 47.23, 22.24, and $23.12 \mathrm{in}$., respectively. The watershed is highly urbanized, and there is a complex system of interbasin water transfers. Water was imported into the basin for public-water supply and as wastewater for treatment and discharge. Ground water was exported from the watershed for public-water supply. Because more water was exported (average of 1.78 in.) than imported (average of $1.64 \mathrm{in}$.) there was a net loss of water from the watershed. Most ground-water withdrawals (average 3.03 in.) were for public and industrial supply, whereas most surfacewater withdrawals (average of 0.09 in.) were for golf-course irrigation. A quarry in the watershed pumped a substantial quantity of ground water (average of $2.9 \mathrm{in}$.) for dewatering. Water pumped for dewatering the quarry was equal, on average, to 49 percent of all ground-water withdrawals in the watershed. This water, discharged to Wissahickon Creek, constituted an average of 25 percent of the base flow of Wissahickon Creek. Discharge of water by sewage-treatment plants, industries, and the quarry (average total of 5.3 in.) caused base flow in the creek to appear higher than it would have been without these 
additional sources and constitutes an average of about 44 percent of the observed base flow. Water imports, exports, withdrawals, and discharges have been steady over time.

The 46.5-square mile Pocono Creek watershed in Pennsylvania is a rural watershed underlain by fractured rock. Water budgets were developed for 1975-2001. Average annual precipitation, streamflow, and ET were 49.70, 22.08, and 27.43 in., respectively. Some water was exported from the watershed (average of $0.18 \mathrm{in}$.) for public-water supply. Most of the residents of the watershed relied on domestic wells and septic systems. Most of the nondomestic ground-water withdrawals (average of 0.52 inches) and all of the surface-water withdrawals (average of 0.09 inches) and discharges (average of 0.07 inches) were by a ski resort. Water exports, withdrawals, and discharges have been increasing over time because of the growth of the ski industry and population increases in the Pocono Creek and surrounding watersheds.

The 77.9-square mile Greenwood Branch of the Rancocas Creek watershed in New Jersey is a rural watershed in the Coastal Plain dominated by forest and wetlands. Water budgets were developed for 1988-2002. Average annual precipitation, streamflow, and ET were 44.73, 18.25, and 23.43 in., respectively. Many private residences relied on domestic wells and septic systems. Most of the water supply, including that from half the domestic wells, came from confined aquifers. The majority of ground-water withdrawals (average of $0.44 \mathrm{in}$.) were for public supply and quarry dewatering (average of $1.14 \mathrm{in}$.). Water pumped for dewatering the sand quarry was equal, on average, to 72 percent of ground-water withdrawals in the watershed. Most surface-water withdrawals (average of $0.62 \mathrm{in}$.) were for public and agricultural supply. The main type of agriculture was cranberry production. Surface water was exported (average of 0.3 in.) for use at the Fort Dix Army Base, which is north of the watershed. Most consumptive use was for cranberry production and sand mining (average 0.14 in.). Ground-water returns (average of $1.42 \mathrm{in}$.) were dominated by water used for cranberry production and quarry dewatering. Surface-water discharge (average of $0.31 \mathrm{in}$.) was mainly from cranberry production.

The 51.3-square mile Cooper River watershed in New Jersey is a mostly urban watershed in the Coastal Plain with an intricate system of water use. The southeastern part of the watershed is rural and was mainly self-supplied. Water budgets were developed for 1988-2002. Average annual precipitation, streamflow, and ET were 44.11, 22.13, and 24.13 in., respectively. Most of the water that was withdrawn and exported from the basin came from confined aquifers. The small amount of water withdrawn from unconfined aquifers (average of less than $0.01 \mathrm{in}$.) and surface-water sources (average $0.77 \mathrm{in}$.) was used for golf-course, agricultural, and nonagricultural irrigation and some industrial purposes. A regional sewer system completed in 1991 dramatically reduced discharge to surface water in the watershed from 2.95 in. in 1988 to 0.01 in. in 1994.

\section{Acknowledgments}

Withdrawal and discharge data were provided by David Sayers of the DRBC. Preston Luitweiler of Aqua Pennsylvania, Inc., Downingtown Municipal Authority, Downingtown Area Regional Authority, Camden County Municipal Utility Authority, and the New Jersey Department of Environmental Protection Bureau of Water Allocation also provided withdrawal and discharge data. GIS data sets were provided by Craig Thomas of the Chester County Water Resources Authority for East Branch Brandywine Creek and by Steven Rinker of the Monroe County Planning Commission for Pocono Creek. Scott Hoffman of the USGS Pennsylvania Water Science Center provided GIS support. Critical reviews of this report were provided by the DRBC, Daryll Pope of the USGS New Jersey Water Science Center, and Marla Stuckey of the USGS Pennsylvania Water Science Center.

\section{References Cited}

Alley, W.M., Reilly, T.E., and Franke, Lehn, 1999, Sustainability of ground-water resources: U.S. Geological Survey Circular 1186, $79 \mathrm{p}$.

Barksdale, E.C., Greenman, D.W., Lang, S.M., Hilton, G.S., and Outlaw, D.E., 1958, Ground-water resources in the TriState Region adjacent to the Lower Delaware River: State of New Jersey Department of Conservation and Economic Development, Division of Water Policy and Supply Special Report 13, 190 p.

Chester County Planning Commission, 1985a, Community facilities inventory Chester County, Pennsylvania Volume 1 sewer facilities: West Chester, Pennsylvania, 167 p.

Chester County Planning Commission, 1985b, Community facilities inventory Chester County, Pennsylvania Volume 2 water facilities: West Chester, Pennsylvania, 212 p.

Chester County Planning Commission, 1991, Water facilities inventory: West Chester, Pennsylvania, $111 \mathrm{p}$.

Chester County Planning Commission, 1996, Water resources use and service in Chester County: West Chester, Pennsylvania, variously paginated.

Chester County Water Resources Authority, 2001, Chester County, Pennsylvania water resources compendium: West Chester, Pennsylvania, CD ROM.

Chester County Water Resources Authority and Chester County Planning Commission, 1979, Water resources inventory study volume 4, Brandywine sub-basin: West Chester, Pennsylvania, $83 \mathrm{p}$.

Delaware River Basin Commission, 1999, Ground water protected area regulations, southern Pennsylvania: West Trenton, New Jersey, $41 \mathrm{p}$.

Delaware River Basin Commission, 2001, Camelback Ski Corporation increased surface water withdrawal Pocono Township, Monroe County, Pennsylvania: Delaware River Basin Commission Docket no. D-2001-40, 6 p. 
Delaware River Basin Commission, 2004, Water resources plan for the Delaware River Basin: West Trenton, New Jersey, $100 \mathrm{p}$.

Durlin, R.R., and Schaffstall, W.P., 2004, Water resources data for Pennsylvania water year 2003: U.S. Geological Survey Water-Data Report PA-03-1, 637 p.

Jenner, C.B., and Lins, H.F., 1991, Climatic atlas of the Delaware River Basin: U.S. Geological Survey Professional Paper 1392, 127 p.

Martin, Mary, 1998, Ground-water flow in the New Jersey Coastal Plain: U.S. Geological Survey Professional Paper 1404-H, 146 p.

McGreevy, L.J., and Sloto, R.A., 1980, Development of a digital model of ground-water flow in deeply weathered crystalline rock, Chester County, Pennsylvania: U.S. Geological Survey Water-Resources Investigations Report 80-2, 42 p.

Nawyn, J.P.,1997, Water use in Camden County, New Jersey, 1991: U.S. Geological Survey Open-File Report 97-12, 39 p.

Rhodehamel, E.C., 1970, A hydrologic analysis of the New Jersey Pine Barrens region: New Jersey Department of Environmental Protection, Division of Water Policy and Supply, Water Resources Circular 22, 35 p.

Rhodehamel, E.C., 1973, Geology and water resources of the Wharton Tract and the Mullica River Basin in Southern New Jersey: New Jersey Department of Environmental Protection Special Report 36, 58 p.
Sloto, R.A., 1994, Geology, hydrology, and ground-water quality of Chester County, Pennsylvania: Chester County Water Resources Authority Water-Resources Report 2, 127 p.

Sloto, R.A. and Crouse, M.Y., 1996, HYSEP: A computer program for streamflow hydrograph separation and analysis: U.S. Geological Survey Water-Resources Investigations Report 96-4040, 46 p.

Thiessen, A.H., 1911, Precipitation for large areas: Monthly Weather Review, v. 29, p. 1082-1084.

U.S. Geological Survey, 2002, Water Resources Data --New Jersey, water year 2002, v. 1: U.S. Geological Survey Water Data Reports NJ-02-1, 364 p.

Voronin, L.M., 2004, Documentation of revisions to the Regional Aquifer System Analysis model of the New Jersey Coastal Plain: U.S. Geological Survey Water-Resources Investigations Report 03-4268, 58 p.

Watt, M.K., Kane, A.C., Charles, E.G., and Storck, D.A., 2003, Hydrology of the unconfined aquifer system, Rancocas Creek area: Rancocas, Crosswicks, Assunpink, Blacks, and Crafts Creek Basins, New Jersey, 1996: U.S. Geological Survey Water-Resources Investigations Report 03-4268, 5 sheets. 